\title{
Environmental Factors That Influence the Location of Crop Agriculture in the Conterminous United States
}

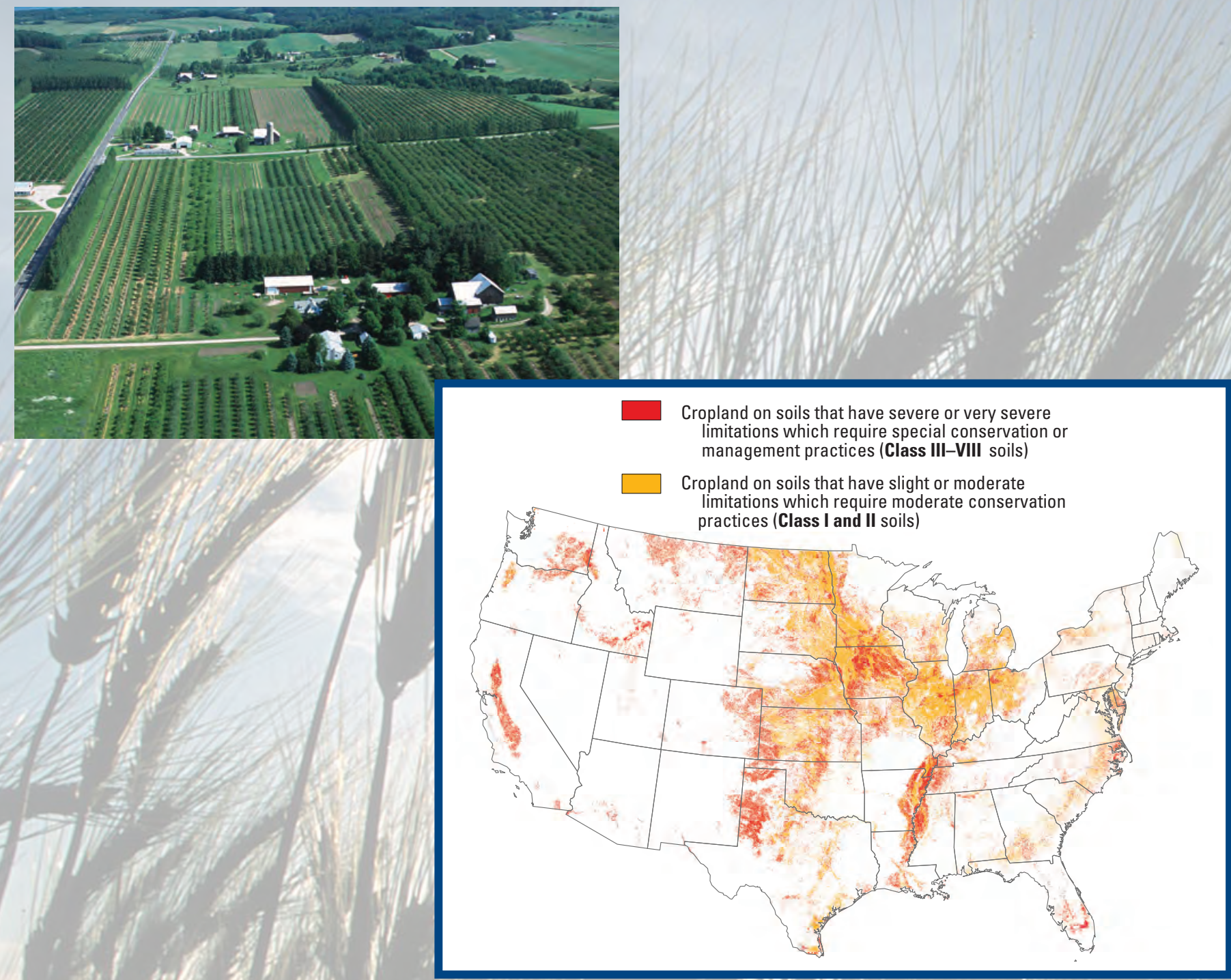

Scientific Investigations Report 2011-5108

U.S. Department of the Interior

U.S. Geological Survey 


\section{Cover photos}

Top foreground: Aerial shot of small farms with orchards, crops, and windbreaks. Leelanau County, Mich. Photo by Lynn Betts (2001), Natural Resources Conservation Service Photo Gallery, NRCSMI01043, http://photogallery.nrcs.gov/.

Background: A grassed backslope terrace in a soybean field in Story County, lowa. Photo by Lynn Betts (2002), Natural Resources Conservation Service Photo Gallery, NRCSIA03005, http://photogallery.nrcs.usda.gov/. 


\section{Environmental Factors That Influence the Location of Crop Agriculture in the Conterminous United States}

By Nancy T. Baker and Paul D. Capel

National Water-Quality Assessment Program

Scientific Investigations Report 2011-5108 


\title{
U.S. Department of the Interior \\ KEN SALAZAR, Secretary \\ U.S. Geological Survey \\ Marcia K. McNutt, Director
}

\author{
U.S. Geological Survey, Reston, Virginia: 2011
}

For more information on the USGS - the Federal source for science about the Earth, its natural and living resources, natural hazards, and the environment, visit http://www.usgs.gov or call 1-888-ASK-USGS.

For an overview of USGS information products, including maps, imagery, and publications, visit http://www.usgs.gov/pubprod

To order this and other USGS information products, visit http://store.usgs.gov

Any use of trade, product, or firm names is for descriptive purposes only and does not imply endorsement by the U.S. Government.

Although this report is in the public domain, permission must be secured from the individual copyright owners to reproduce any copyrighted materials contained within this report.

Suggested citation:

Baker, N.T., and Capel, P.D., 2011, Environmental factors that influence the location of crop agriculture in the conterminous United States: U.S. Geological Survey Scientific Investigations Report 2011-5108, 72 p. 


\section{Foreword}

The U.S. Geological Survey (USGS) is committed to providing the Nation with reliable scientific information that helps to enhance and protect the overall quality of life and that facilitates effective management of water, biological, energy, and mineral resources (http://www.usgs. gov/. Information on the Nation's water resources is critical to ensuring long-term availability of water that is safe for drinking and recreation and is suitable for industry, irrigation, and fish and wildlife. Population growth and increasing demands for water make the availability of that water, measured in terms of quantity and quality, even more essential to the long-term sustainability of our communities and ecosystems.

The USGS implemented the National Water-Quality Assessment (NAWQA) Program in 1991 to support national, regional, State, and local information needs and decisions related to water-quality management and policy (http://water.usgs.gov/nawqa). The NAWOA Program is designed to answer: What is the quality of our Nation's streams and groundwater? How are conditions changing over time? How do natural features and human activities affect the quality of streams and groundwater, and where are those effects most pronounced? By combining information on water chemistry, physical characteristics, stream habitat, and aquatic life, the NAWQA Program aims to provide science-based insights for current and emerging water issues and priorities. From 1991 to 2001, the NAWQA Program completed interdisciplinary assessments and established a baseline understanding of water-quality conditions in 51 of the Nation's river basins and aquifers, referred to as Study Units (http://water.usgs.gov/nawqa/ studies/study_units.html.

National and regional assessments are ongoing in the second decade (2001-2012) of the NAWQA Program as 42 of the 51 Study Units are selectively reassessed. These assessments extend the findings in the Study Units by determining water-quality status and trends at sites that have been consistently monitored for more than a decade, and filling critical gaps in characterizing the quality of surface water and groundwater. For example, increased emphasis has been placed on assessing the quality of source water and finished water associated with many of the Nation's largest community water systems. During the second decade, NAWQA is addressing five national priority topics that build an understanding of how natural features and human activities affect water quality, and establish links between sources of contaminants, the transport of those contaminants through the hydrologic system, and the potential effects of contaminants on humans and aquatic ecosystems. Included are studies on the fate of agricultural chemicals, effects of urbanization on stream ecosystems, bioaccumulation of mercury in stream ecosystems, effects of nutrient enrichment on aquatic ecosystems, and transport of contaminants to public-supply wells. In addition, national syntheses of information on pesticides, volatile organic compounds (VOCs), nutrients, trace elements, and aquatic ecology are continuing.

The USGS aims to disseminate credible, timely, and relevant science information to address practical and effective water-resource management and strategies that protect and restore water quality. We hope this NAWQA publication will provide you with insights and information to meet your needs and will foster increased citizen awareness and involvement in the protection and restoration of our Nation's waters. 
The USGS recognizes that a national assessment by a single program cannot address all water-resource issues of interest. External coordination at all levels is critical for cost-effective management, regulation, and conservation of our Nation's water resources. The NAWQA Program, therefore, depends on advice and information from other agencies-Federal, State, regional, interstate, Tribal, and local—as well as nongovernmental organizations, industry, academia, and other stakeholder groups. Your assistance and suggestions are greatly appreciated.

William H. Werkheiser

USGS Associate Director for Water 


\section{Acknowledgments}

The authors thank Dr. Leonard Coop, Research professor, Integrated Plant Protection Center, Oregon State University, Corvallis, for providing the 1971-2000 Normal Growing Degree-Day geospatial data.

The authors also express gratitude to Norman Bliss, U.S. Geological Survey, Earth Resources Observation and Science Center, for providing historical population and census of agricultural compilations and historical county-boundary geospatial data. The authors express gratitude to David M. Wolock, U.S. Geological Survey, Kansas Water Science Center, for providing updated average annual runoff (1970-2001) and recharge geospatial datasets. Finally, the authors thank Frank D. Voss and David C. Lampe, U.S. Geological Survey, for technical review of the material presented in this document. 



\section{Contents}

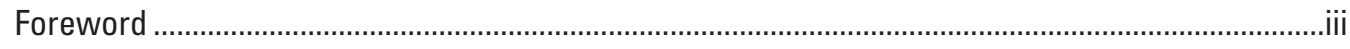

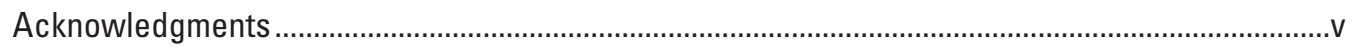

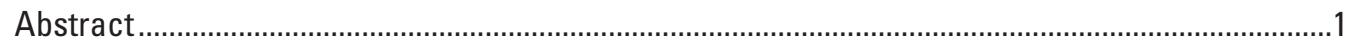

Introduction: Why Is Crop Agriculture Located Where It Is? .........................................................2

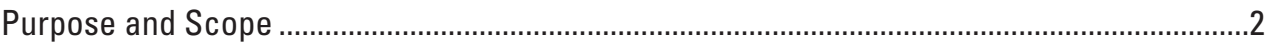

Development of Croplands in the United States...........................................................................

Environmental Factors That Influence the Location of Crop Agriculture.........................................8

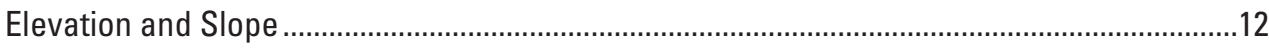

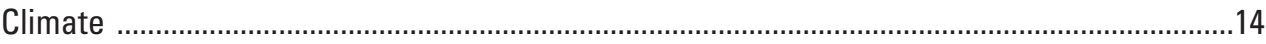

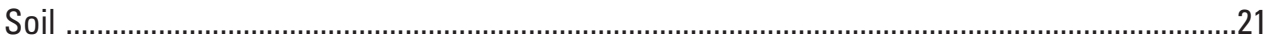

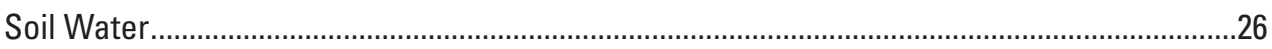

Other Land Uses in Competition for Agricultural Lands ................................................................32

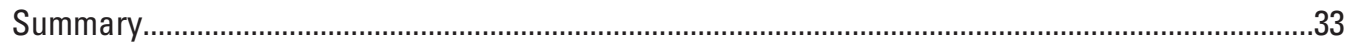

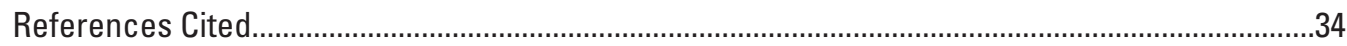

Appendix 1-Development of Croplands in the United States .........................................................38

Appendix 2-Environmental Factors That Influence the Location of Crop Agriculture .................39

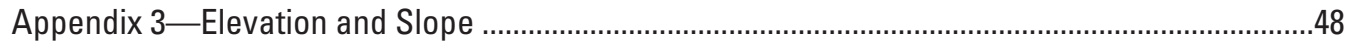

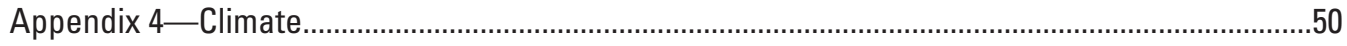

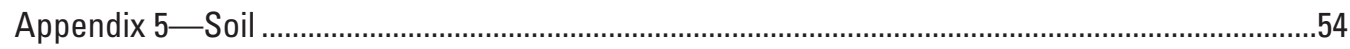

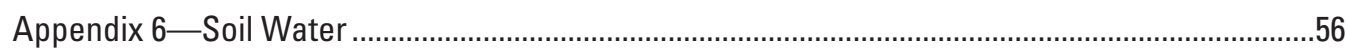

Appendix 7-Other Land Uses in Competition for Agricultural Lands ...........................................61

Appendix 8-Summary of Data Sources and Online Links to Datasets ........................................65

References Cited in the Appendixes ..................................................................................................

\section{Figures}

1. Potential natural vegetation of the conterminous United States .......................................3

2. Historical extent of settled area for people of primarily European descent,

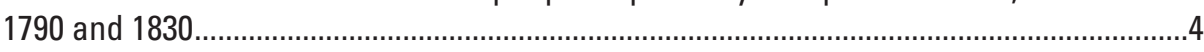

3. Extent of improved farmland for selected census years for the conterminous United States, 1850-2002 ....................................................................5

4. Trends in harvested cropland for the conterminous United States, 1879-2002 ................6

5. Location of grassland and cropland, and total land area in each crop or crop group in the conterminous United States, 2009.

6. Extent of cropland and total acreage grown for selected grain and specialty crops in the United States, 2007.

7. Location of cropland in each slope range and the percentage of cropland area for each slope range for selected crops in the conterminous United States.

8. Location of crops on land with 3 percent or greater slope and location of other cropland in the conterminous United States. 
9. Location of cropland and average growing degree-days for base $50^{\circ} \mathrm{F}$ (1971-2000) and the percentage of cropland area for each growing degree-day category for selected crops in the conterminous United States.

10. Location of cropland and average annual precipitation (1971-2000) and the percentage of cropland area for each precipitation category for selected crops in the conterminous United States.

11. Extent of favorable climate for growing selected crops based on average annual growing degree-days and precipitation (1970-2001) and location of selected crops for the conterminous United States.

12. Extent of irrigated cropland from surface water and groundwater sources in the conterminous United States

13. Extent of irrigated cropland and percentage of harvested cropland that is irrigated for selected crops in the conterminous United States, 2007

14. Areas of groundwater-level decline and the extent of cropland in areas that have groundwater-level decline in the conterminous United States

15. Distribution of cropland treated with commercial fertilizer, lime, and soil conditioners and land treated with manure; and percentage of all cropland (including hay) treated with commercial fertilizer, lime, and soil conditioners and percentage of land treated with nitrogen, phosphorus, and potash for selected crops in the conterminous United States, 1989-2007

16. Location of cropland on each land capability class and the percentage of cropland area for each capability class for selected crops in the conterminous United States.

17. Location of cropland on soils that have severe or very severe limitations which require special conservation or management practices and cropland on soils that have slight or moderate limitations which require moderate conservation practices in the conterminous United States.

18. Location of cropland on each soil hazard class and the percentage of cropland area for each soil hazard class for selected crops in the conterminous United States

19. Location of cropland on soils in each hazard class (climate, erosion, soils, and water) in the conterminous United States

20. Cropland on soils where surface or subsurface artificial drainage is likely required to remove excess water in order to cultivate cropland in the conterminous United States

21. Location of cropland and average annual runoff (1971-2000) and the percentage of cropland area for each runoff category for selected crops in the conterminous United States

22. Location of cropland and average annual recharge (1971-2000) and the percentage of cropland area for each recharge category for selected crops in the conterminous United States.

23. Location of cropland on potential natural vegetation and the percentage of cropland area in each natural vegetation type for selected crops in the conterminous United States 


\section{Appendix Tables}

2-1. 2009 Cropland Data Layer land-cover codes and land-cover groups used in this report.

2-2. Land area in each crop or crop group in the 2009 Cropland Data Layer for the conterminous United States.

2-3. Area of land in each land cover group for the 2009 Cropland Data Layer for the conterminous United States.

2-4. Comparison of land area in each land-cover group reported in "Major Uses of Land, 2002" and the 2009 Cropland Data Layer, and estimated land area for land-cover groups not differentiated in the 2009 Cropland Data Layer for the conterminous United States.

2-5. Total acreage grown for selected grain and specialty crops for the conterminous United States

3-1. Land area in each crop or crop group above 2,000 meters elevation in the 2009 Cropland Data Layer for the conterminous United States

3-2. Land area in each crop or crop group for each slope range in the 2009 Cropland Data Layer for the conterminous United States

4-1. Land area in each crop or crop group for each growing degree-day range in the 2009 Cropland Data Layer for the conterminous United States .51

4-2. Land area in each crop or crop group for precipitation category in the 2009 Cropland Data Layer for the conterminous United States

4-3. Optimal and sub-optimal heat and water requirements for selected crops

4-4. Total irrigated acreage for selected crops for 2007 for the conterminous United States

5-1. Land area in each crop or crop group for each land capability class in the 2009 Cropland Data Layer for the conterminous United States

6-1. Land area in each crop or crop group for each land hazard class in the 2009 Cropland Data Layer for the conterminous United States

6-2. Land area in each crop or crop group that is artificially drained in the 2009 Cropland Data Layer for the conterminous United States

6-3. Land area in each crop or crop group for each runoff category in the 2009 Cropland Data Layer for the conterminous United States

6-4. Land area in each crop or crop group for each recharge category in the 2009 Cropland Data Layer for the conterminous United States

7-1. Land area in each potential natural vegetation type converted to cropland, and grassland and hay for the conterminous United States.

7-2. Land area in each crop or crop group for each potential natural vegetation type in the 2009 Cropland Data Layer for the conterminous United States

7-3. Land area for each potential natural vegetation class in cropland and in grassland. .66

8-1. Summary of data sources and online links to datasets 


\section{Conversion Factors}

\begin{tabular}{lcl}
\hline \multicolumn{1}{c}{ Multiply } & \multicolumn{1}{c}{ By } & \multicolumn{1}{c}{ To obtain } \\
\hline centimeter $(\mathrm{cm})$ & 0.3937 & inch (in.) \\
millimeter $(\mathrm{mm})$ & 0.03937 & inch (in.) \\
meter $(\mathrm{m})$ & 3.281 & foot (ft) \\
kilometer $(\mathrm{km})$ & 0.6214 & mile (mi) \\
\hline & Area & \\
\hline acre & 0.4047 & hectare (ha) \\
hectare (ha) & 2.471 & acre \\
hectare (ha) & 0.003861 & square mile (mi $\left.{ }^{2}\right)$ \\
square kilometer $\left(\mathrm{km}^{2}\right)$ & 0.3861 & square mile (mi $\left.{ }^{2}\right)$ \\
\hline & Volume & \\
\hline hectare-meter (ha-m) & 8.107 & acre-foot (acre-ft) \\
\hline millimeter per year $(\mathrm{mm} / \mathrm{yr})$ & 0.03937 & inch per year (in/yr) \\
\hline
\end{tabular}

Temperature in degrees Fahrenheit $\left({ }^{\circ} \mathrm{F}\right)$ may be converted to degrees Celsius $\left({ }^{\circ} \mathrm{C}\right)$ as follows:

${ }^{\circ} \mathrm{C}=\left({ }^{\circ} \mathrm{F}-32\right) / 1.8$ 


\title{
Environmental Factors That Influence the Location of Crop Agriculture in the Conterminous United States
}

\author{
By Nancy T. Baker and Paul D. Capel
}

\begin{abstract}
This report presents and describes high-resolution geospatial data identifying the range of environmental conditions that influence the location of cropped agricultural lands in the conterminous United States. Also presented are estimates of the extent of land where environmental constraints limit agricultural production (marginal land) and the extents of land where modifications overcome environmental constraints. The report is the result of the compilation and manipulation of datasets from numerous sources; it consists of an explanatory text and a series of appendixes and associated tables that document the data sources and data-manipulation methods in detail.

Environmental factors that influence the extent of crop agriculture are terrain, climate, soil properties, and soil water. It is the combination of these four factors that allow specific crops to be grown in certain areas. Today, in order to maximize production, most of the cultivated croplands and
\end{abstract}

grasslands for commercial agriculture are in areas where crops and livestock are well suited to local conditions. In the United States, cropland (row crops, closely sown crops (except hay), fruits, nuts, vegetables) occupies about 13 percent of the total land area. Grassland and rangeland occupy another 41 percent of the land area.

Most crops are grown on land with shallow slope where the temperature, precipitation, and soils are favorable. In areas that are too steep, wet, or dry, landscapes have been modified to allow cultivation. Some of the limitations of the environmental factors that determine the location of agriculture can be overcome through modifications, but others cannot. On a larger-than-field scale, agricultural modifications commonly influence water availability through irrigation and (or) drainage and soil fertility and (or) organic-matter content through amendments such as manure, commercial fertilizer, and lime. In general, it is not feasible to modify the other environmental factors, soil texture, soil depth, soil mineralogy, temperature, and terrain at large scales. 


\section{Introduction: Why Is Crop Agriculture Located Where It Is?}

Environmental, economic, and societal factors have determined the location of crop agriculture. The environmental factors influencing the extent of arable land are terrain, climate, soil properties, and soil water. Crops need space to grow, sufficient light, warmth, and moisture. Soils must be of sufficient depth with sufficient drainage, texture, and chemical and fertility properties. Terrain must be neither too rugged nor at too high an elevation for accessibility, with slopes gentle enough to prevent soil and nutrient loss yet steep enough to prevent flooding. Of these environmental characteristics, only soil water and soil fertility can be significantly modified over large areas. Irrigation, drainage, and fertilization allow for crops to thrive in areas where environmental factors alone would not meet their basic needs.

On a subsistence level, land is modified for agriculture almost everywhere people settle. The exceptions are the most inhospitable areas of the world - extremely cold, dry, or rugged lands - where subsistence is derived from hunting and gathering food. Commercial agriculture, the production of crops and livestock intended for widespread distribution and consumption by others, requires a narrower and more optimal range of environmental conditions for productivity and profitability. Often, agricultural modifications are necessary to increase the productivity of agricultural lands. Beyond the normal tilling of the land, farmers use fertilizers and pesticides to increase soil fertility and crop yield, reshape the land surface to minimize erosion and loss of nutrients, drain wetlands, and irrigate dry lands to increase crop productivity in areas once considered marginal for agricultural use.

\section{Purpose and Scope}

This report presents and describes high-resolution geospatial data identifying the range of environmental conditions that influence the location of cropped agricultural lands in the conterminous United States. Also presented are estimates of the extent of land where environmental constraints limit agricultural production (marginal land) and the extents of land where modifications overcome environmental constraints.

This report is the result of the compilation and manipulation of datasets from numerous sources. Specifically, it consists of an illustrated explanatory text plus a series of appendixes and associated tables that document the data sources and data-manipulation methods in detail. It is intended for scientists who study the effects of agricultural practices on water and air quality but do not normally study "why agriculture is located in a given area." Throughout, we strive to highlight the relationship between environmental conditions that result in conversion of land from its natural state to agricultural use and the subsequent modifications to the landscape (disturbance of the soil, irrigation, artificial drainage, application of nutrients, and so forth) in order to promote better understanding of how those modifications affect environmental processes.
In addition, analysis of spatial and temporal patterns for the location of agriculture may provide insight into future cropproduction potential.
"Water scarcity, together with degradation of arable land, could become the most serious obstacle to future increases in food production." (Fischer and others, 2002)

\section{Development of Croplands in the United States}

Before human settlement, the North American landscape consisted of forest, grasslands, and scrublands (fig. 1). Adequate precipitation to support tree growth generally defined the forest-grassland boundary. Areas with insufficient precipitation to support grass gave way to scrubland. Deciduous broadleaf forests once covered most of the East, the Ohio and lower Mississippi River Valleys, and the middle Great Lakes region (Küchler, 1964). Needleleaf forests covered much of the central and northern Pacific Coast, the higher elevations of the West, parts of the interior North, and a narrow belt in the Deep South. Grasslands covered much of the sub-humid interior lowlands of the Great Plains from Texas and New Mexico to the Canadian border. An eastward extension of the grasslands, the Prairie Wedge, reached across Illinois to the western edge of Indiana, where precipitation is clearly adequate to support tree growth (Birdsall and others, 1999). Scrublands were concentrated in the arid lowlands of the interior West. Vegetation varied from the cacti of the Southwest to the dense, brushy chaparral of southern California and the mesquite of Texas (Birdsall and others, 1999).

Native Americans began farming the North American continent as early as 5,000 B.C.E. Nearly 1,000 years before European settlement, native farmers developed a productive agricultural system based on corn, beans, and squash (Hurt, 1994). They successively adapted their crops to meet the environmental conditions of their regions - developing varieties that would grow in the cool regions along the Canadian border and other varieties that would grow in the hot, dry southwest.

Agriculture for European settlers began in Jamestown in 1607 and in Plymouth in 1620 when the colonists learned from the Native Americans to plant corn (fig. 2). However, English settlers did not recognize or acknowledge much of Native American agricultural patterns already in place and fundamentally changed the landscape by importing cows, sheep, bees, and apple trees (Horn, 2005). Southern farmers began commercial production of tobacco as early as 1612 . New England farmers commercially produced livestock as well as grain. Little attention was given to crop rotation, fertilization, or proper tillage practices, so these early farmers raised crops until the soils became depleted then migrated onto adjacent lands in search of more profitable and fertile land; for example, wheat production declined in New England because of depleted soils but became a staple of the middle colonies of New York, Pennsylvania, and New Jersey (Hurt, 1994). Farmers began raising rice as early as 1671 in South Carolina. 


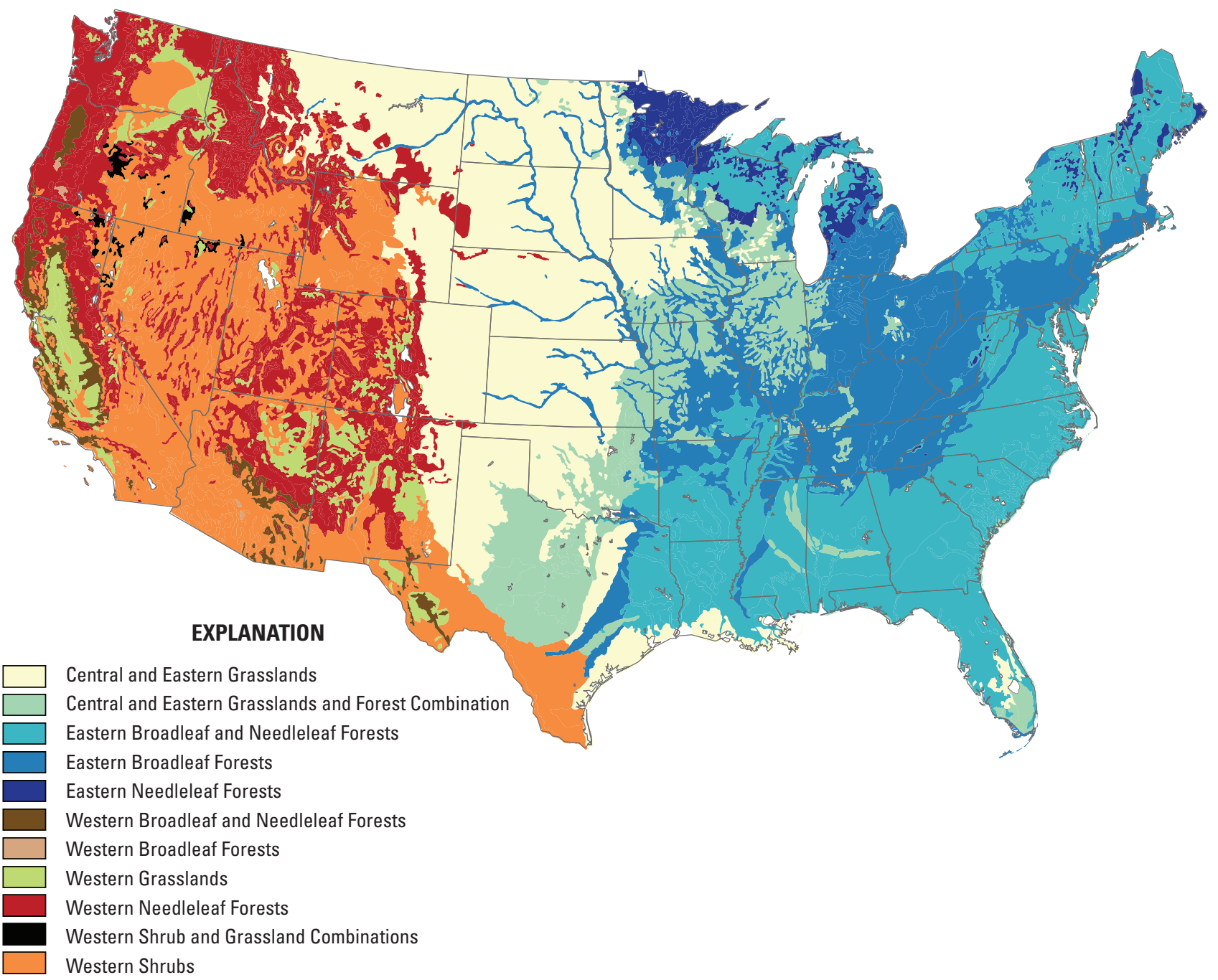

Figure 1. Potential natural vegetation of the conterminous United States (Missoula Fire Sciences Laboratory, 2001). 
During the 18th century, commercial agriculture spilled across the Appalachians and swept along the Gulf Coast (Hurt, 1994). At that time, rivers were the primary transportation routes; therefore, commercial agriculture thrived along river areas where farm produce could easily be shipped to market. Products were limited to nonperishable commodities such as tobacco, rice, wheat, corn, and salt meat (Hurt, 1994). In the early 1700 s, the Spanish began to colonize the upper Rio Grande Valley. Agriculture was primarily cattle production, and crops were limited to subsistence farming. Grapes were introduced to California around 1780. Spanish missionaries introduced a variety of crops such as wheat, oats, barley, onions, peas, watermelons, muskmelons, peaches, apricots, and apples (Hurt, 1994).

After the "Indian Removal Act" of the 1830s, European settlement extended rapidly westward. The "Homestead Act" of the 1860s (and the expanded act of the 1900s) was supposed to encourage agricultural settlement in the Great Plains (fig. 3). The act was often abused. In these arid areas, the plot of land allotted was generally too small for a viable farm (at least prior to major public investments in irrigation projects), so homesteads were instead used to control resources, especially water. The "Enlarged Homestead Act" of 1909 gave 320 acres $\left(1.3 \mathrm{~km}^{2}\right)$ to farmers who accepted more marginal lands, which at the time could not be easily irrigated. A massive influx of new farmers eventually led to extensive land erosion and the Dust Bowl of the 1930s (fig. 3).

Continued migration brought settlers and agriculture across the Great Plains to the Western States. Mormon settlers began producing potatoes in Idaho in the mid-1800s. Around the same time, the Willamette Valley became the destination of choice for emigrants on the Oregon Trail. Major agricultural products included a variety of berries and vegetables and, more recently, grape and wine production. By 1910, California had developed large-scale fruit and vegetable agriculture based on extensive lands, irrigation, railroad and steamer transportation, and strong marketing cooperatives (Hurt, 1994). Irrigation made the Central and Imperial Valleys of California one of the most productive agricultural areas in the world.

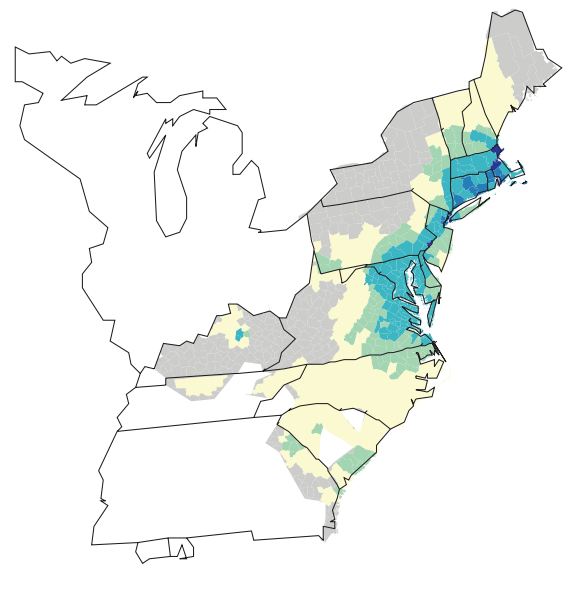

1790
EXPLANATION

Population density, in people per square kilometer

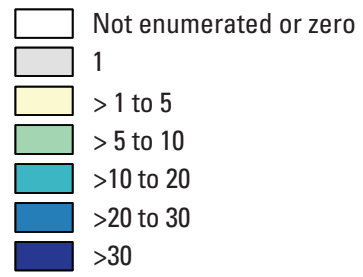

Figure 2. Historical extent of settled area for people of primarily European descent, 1790 and 1830 (Waisanen and Bliss, 2002). Population density is used as a surrogate for agricultural lands because agricultural census data are not available before 1850 . 

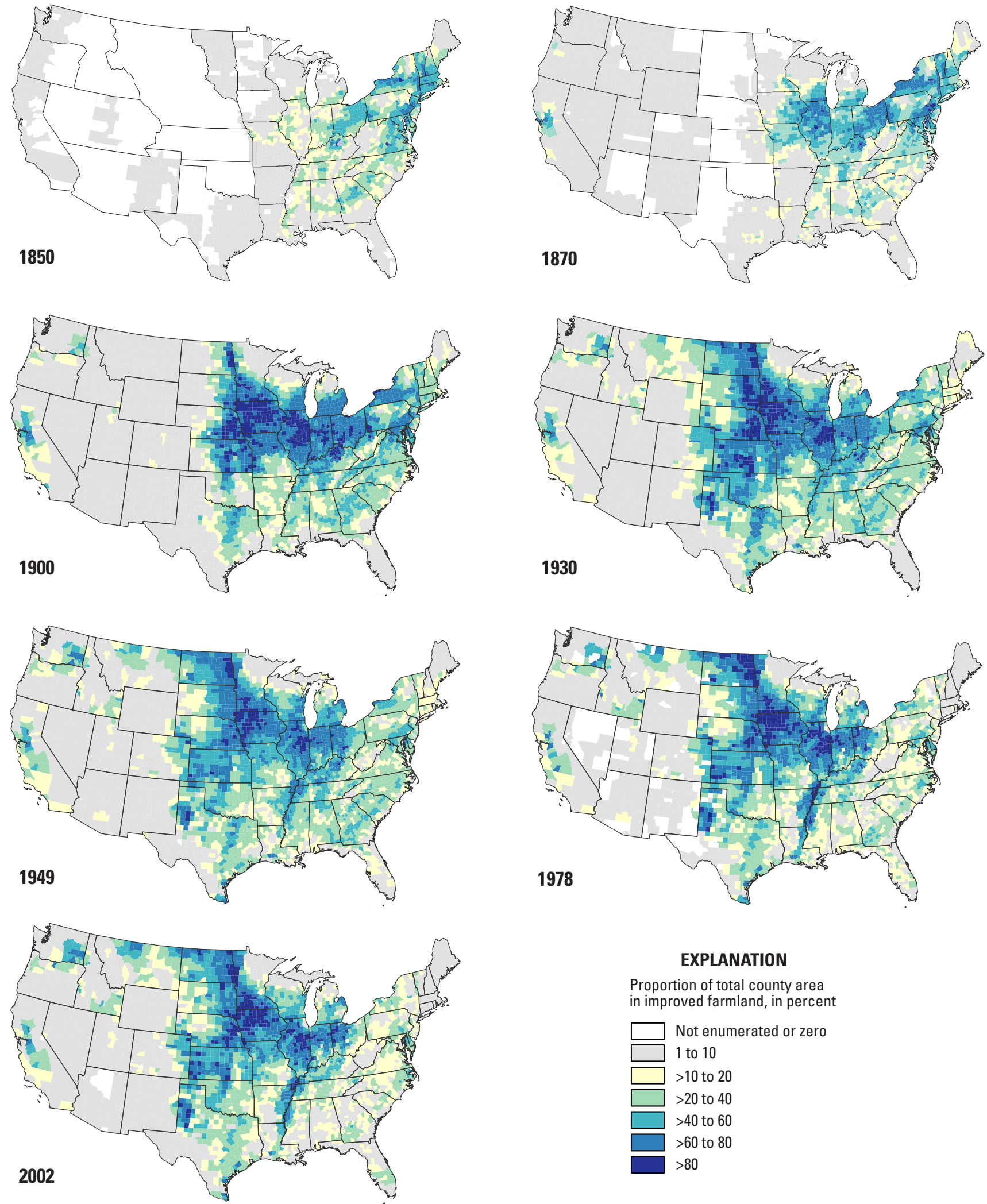

\section{EXPLANATION}

Proportion of total county area in improved farmland, in percent

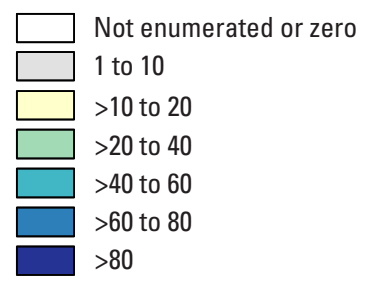

Figure 3. Extent of improved farmland for selected census years for the conterminous United States, 1850-2002 (Waisanen and Bliss, 2002; U.S. Department of Agriculture, 2005). 


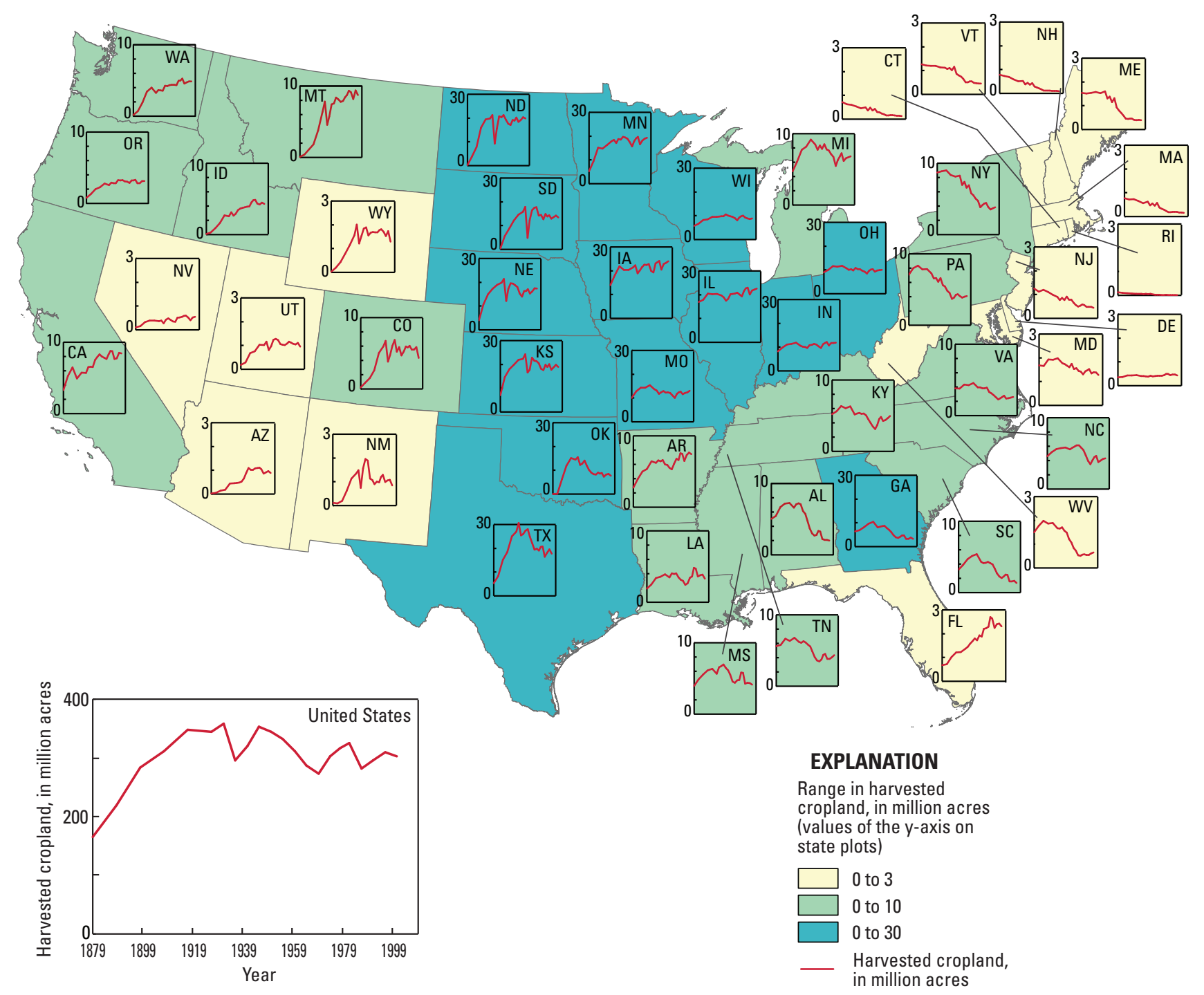

Figure 4. Trends in harvested cropland for the conterminous United States, 1879-2002 (Ramankutty and others, 2010).

Along with westward expansion, the extent of harvested cropland has changed in different parts of the country (fig. 4). In the East and South, total cropland area has declined in most states. The exception is Florida, where cropland area steadily increased through the 20th century. The midwestern Corn Belt increased in cropland area during early westward expansion and has remained fairly stable for the past century. The
Northern and Southern Plains states show a dip in cropland area corresponding to the severe drought and Dust Bowl of the 1930s. Cropland area increased in the Northern Plains after the 1930s. New Mexico, Texas, and Oklahoma have declined in cropland area in the last 50 years. Most of the Western States have increase cropland area over the last century (fig. 4). 


\section{Environmental Factors That Influence the Location of Crop Agriculture}

The range of environmental conditions conducive to the production of crops is wide, and particular combinations of these environmental conditions allow specific crops to be grown in certain areas. Obviously, in areas with rugged slopes, poor soils, and inhospitable climate, commercial agriculture would not be profitable or perhaps even possible. In other areas, commercial agriculture is very profitable, and environmental conditions are such that many types of high-yielding crops can be grown. However, most agricultural lands fall somewhere between the two ends of the spectrum.

Agriculture has evolved over time. Early agriculture was primarily for subsistence, and farmers produced a diversity of crops and livestock in order to survive. In subsistence farming, the crops or livestock grown may not be particularly suited to the environmental conditions of the area. Today, most of the cultivated cropland and grassland for livestock is used for commercial purposes. Unlike subsistence farmers, commercial farmers tend to grow crops that are suited to the particular conditions of the areas where they farm in order to maximize profits for a given piece of land.

Currently in the United States, cropland occupies about 13 percent of the total land area (fig. 5) Croplands include row and closely sown crops (except hay), tree fruits and nuts, and vegetables and ground fruits. (Appendix 2, table 2-1, is a detailed list of land-cover categories used in this document.) Grassland (pasture and hay) occupy another 25 percent of the land area (appendix 2, tables 2-2 and 2-3). Pastures are those lands that are seeded and used primarily for the production of adapted, domesticated forage plants (for example, tall fescue or switchgrass) for livestock. Hay includes grasses and legumes — such as timothy and alfalfa — which are typically cut, dried, and stored for livestock fodder. Rangelands, which occupy another 16 percent of the land area, are those lands on which the native vegetation (climax or natural potential plant community) is predominantly grass, grasslike plants, and shrubs suitable for grazing or browsing (appendix 2, table 2-4). Rangelands include natural grassland, savannas, many wetlands, some deserts, tundra, and certain forb and shrub communities.

What combinations of terrain, climate, soils, and soil water determine the spatial distribution of specific crops? What environmental conditions result in the predominance of corn and soybeans in the Midwest and the predominance of rice along the Mississippi Valley (fig. 5)? Why is cotton clustered in the panhandle of Texas, the majority of wheat spread along the eastern edge of the Great Plains, and citrus primarily grown in selected areas of California, southern Texas, and Florida? Why is it that nearly all oilseeds, beans and peas, and sugar beets are grown in the Northern Plains, tobacco is primarily confined to Kentucky and North Carolina, and peanuts are grown in a southern band from South Carolina to Alabama (fig. 6; appendix 2, table 2-5)? The inherent characteristics of terrain, climate, soil, and water influence not only the location and types of crops grown in specific areas but also the agricultural modifications necessary to sustain profit and yield. Human-induced changes to the land such as accelerated erosion, accumulation of salts, and water removal or addition (artificial drainage, supplies of irrigation water) also influence the types of crops grown and the types of modifications implemented in certain areas. 

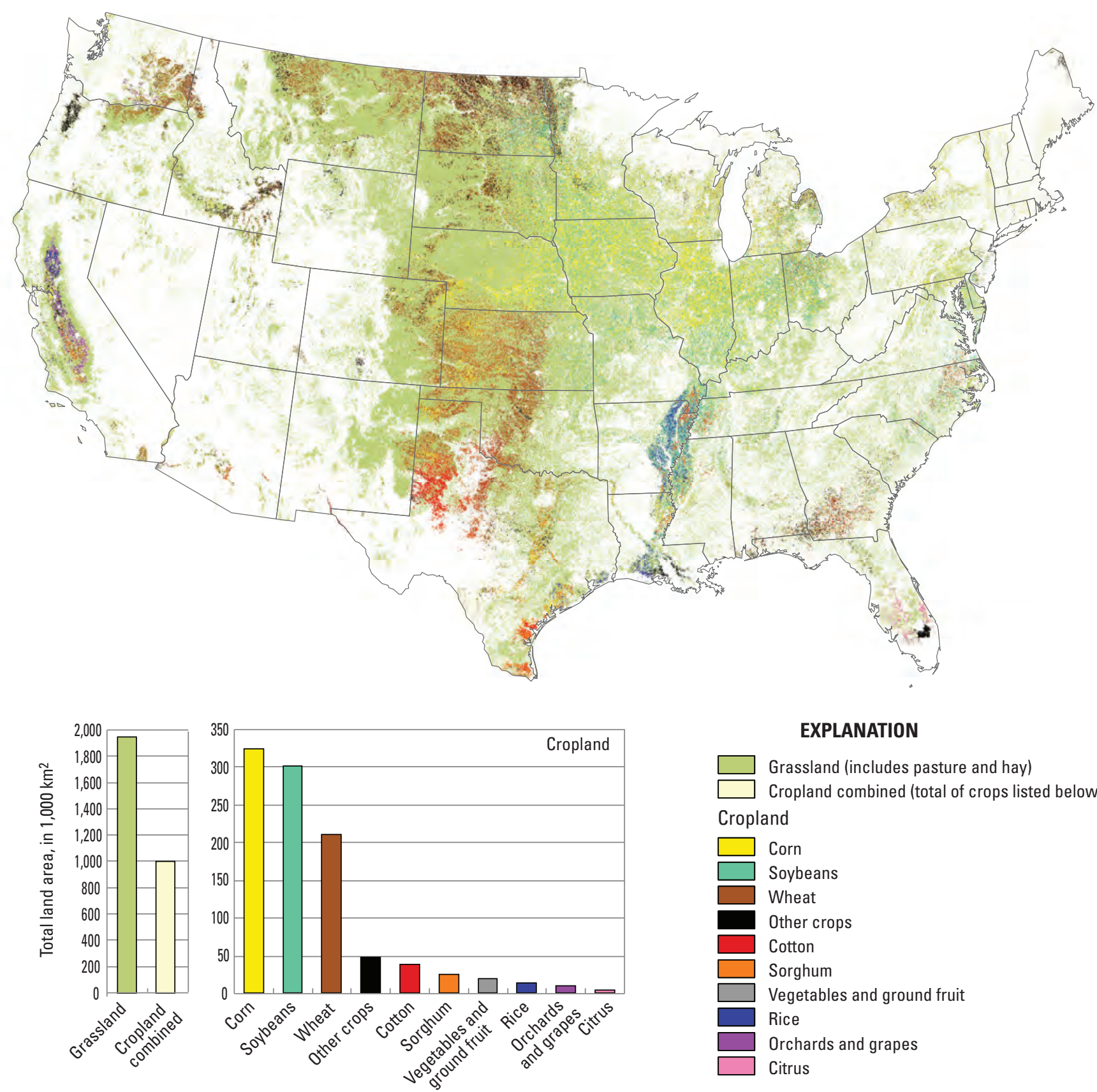

\section{EXPLANATION}

Grassland (includes pasture and hay)

Cropland combined (total of crops listed below) Cropland

\begin{tabular}{l}
\hline Corn \\
\hline Soybeans \\
Wheat \\
Other crops \\
Cotton \\
$\square$ Sorghum \\
$\square$ Vegetables and ground fruit \\
Rice \\
\hline Orchards and grapes \\
\hline Citrus
\end{tabular}

Figure 5. Location of grassland and cropland, and total land area in each crop or crop group in the conterminous United States, 2009 (U.S. Department of Agriculture, 2010b). 

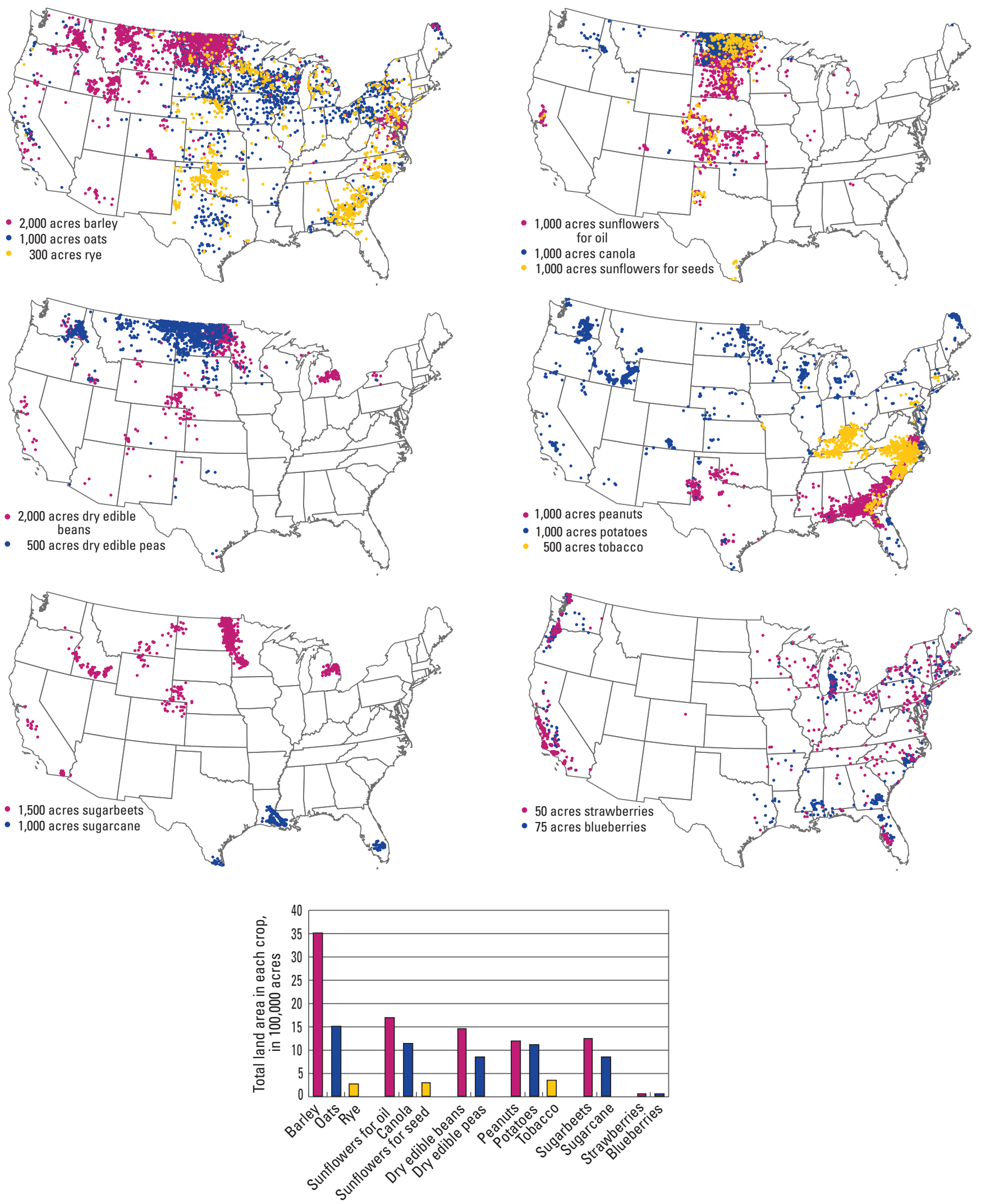

Figure 6. Extent of cropland and total acreage grown for selected grain and specialty crops in the United States, 2007 (U.S. Department of Agriculture, 2009a). 


\section{Elevation and Slope}

Agricultural land used for commercial production is constrained by both elevation and slope. For agricultural production, high elevations have similar constraints as high latitudes, including decreased temperature, increased wind velocity, and poor soil. It is these secondary characteristics that constrain crop cultivation rather than high elevation itself (Singh and Dhillon, 2004). Terrain that is too rugged (steep slopes) is not readily accessible for mechanized agriculture. In addition, terrain indirectly effects soil formation, modifies climates, and affects water drainage and availability. Steep slopes are subject to soil and nutrient loss. In contrast, very flat terrain is prone to flooding and poorly drained soils.

Only a few locations in the conterminous United States are constrained by too high elevation for commercial agriculture. About 1 percent of crops are grown at elevations higher than 2,000 m (appendix 3, table 3-1). Wheat, "other crops" (including grasses such as rye, oats, and barley), and vegetables and ground fruit make up most of the crops grown above 2,000 m (appendix 3, table 3-1).
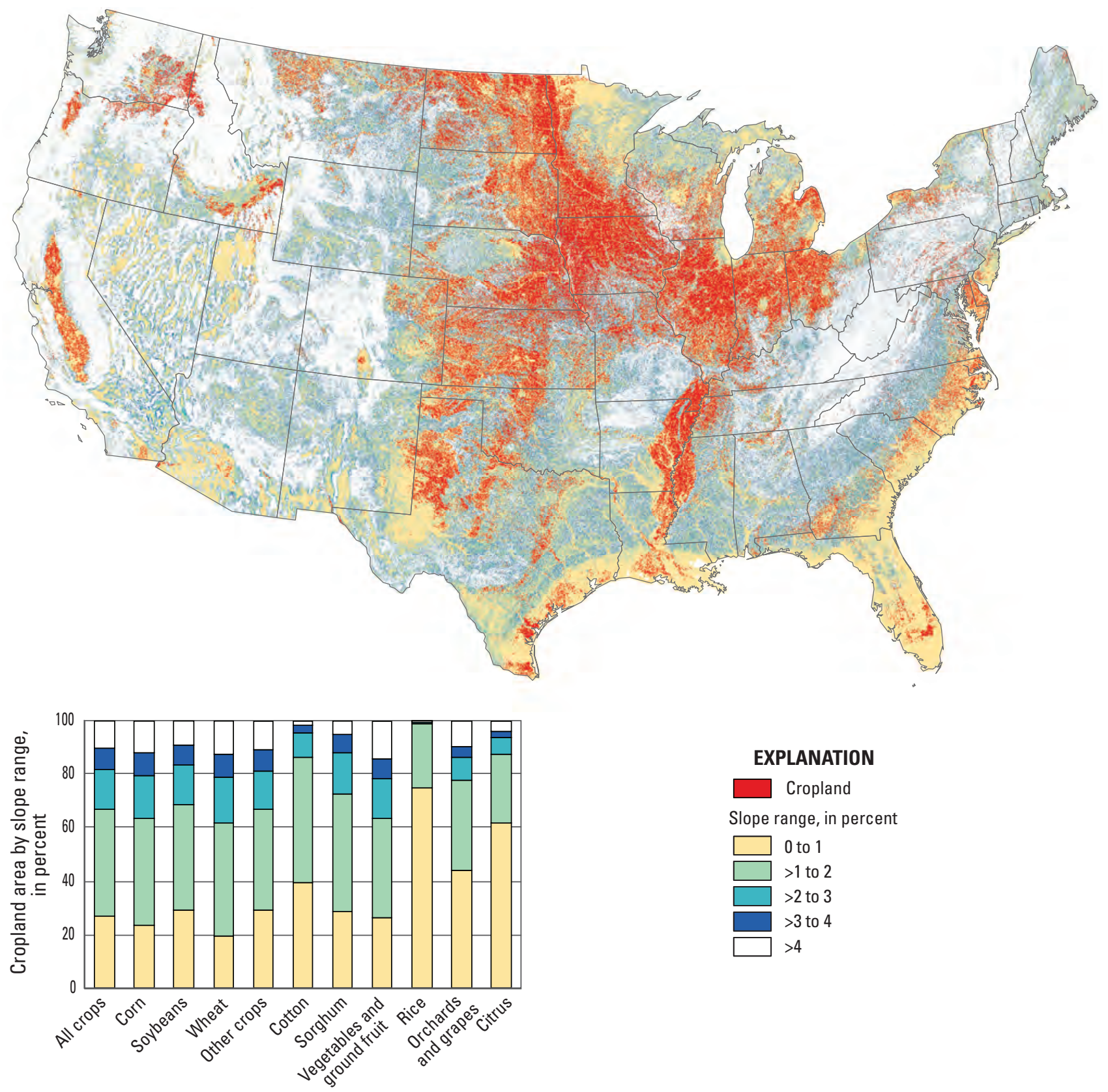

\section{EXPLANATION}

Cropland

Slope range, in percent

\section{0 to 1}

$>1$ to 2

$>2$ to 3

$>3$ to 4

$>4$

Figure 7. Location of cropland in each slope range and the percentage of cropland area for each slope range for selected crops in the conterminous United States (Falcone, 2003; U.S. Department of Agriculture, 2010b). 
The slope of the landscape effects soil formation, climate, water drainage, and soil-water availability. Steep slopes are subject to erosion and soil loss. Steep slopes are also not readily accessible for farm machinery (Singh and Dillon, 2004).

Areas that are nearly level ( 0 to 3 percent slope) are generally excellent for row-crop agriculture, although some of these areas are naturally wetlands. These nearly level slopes present no constraint for farm machinery. Gently rolling areas (3 to 6 percent slopes) present no serious obstacles to cultivation; occasionally, substantial rainstorms can cause soil erosion, so terracing is implemented in some of these areas. Crop agriculture is limited in areas with slopes greater than 6 percent because of erosion and machinery constraints. Slopes that are too steep for row crops may still be suitable for orchards, vineyards, and animal grazing.
About 80 percent of all crops are grown on land with a slope of 3 percent or less (fig. 7) (appendix 3, table 3-2). Nearly all cotton, rice, and citrus are grown on land with a slope of 2 percent or less. About 10 percent of all crops are grown on slopes greater than 4 percent, and only a small percentage of all crops are grown on steeper slopes (5 to 16 percent). The crops grown on steeper slopes are tree fruits, grapes, vegetables, and "other grains." The areas of the country where crops are more likely to be grown on steeper slopes are along the border between Iowa and Nebraska, in western New York, along the Appalachian Mountains, and in southern Idaho and eastern Washington (fig. 8). A much larger percentage of grassland has steeper slopes than cropland; in fact, about 22 percent of grassland is grown on slopes steeper than 5 percent, because steeper slopes are generally unsuited to cultivation.

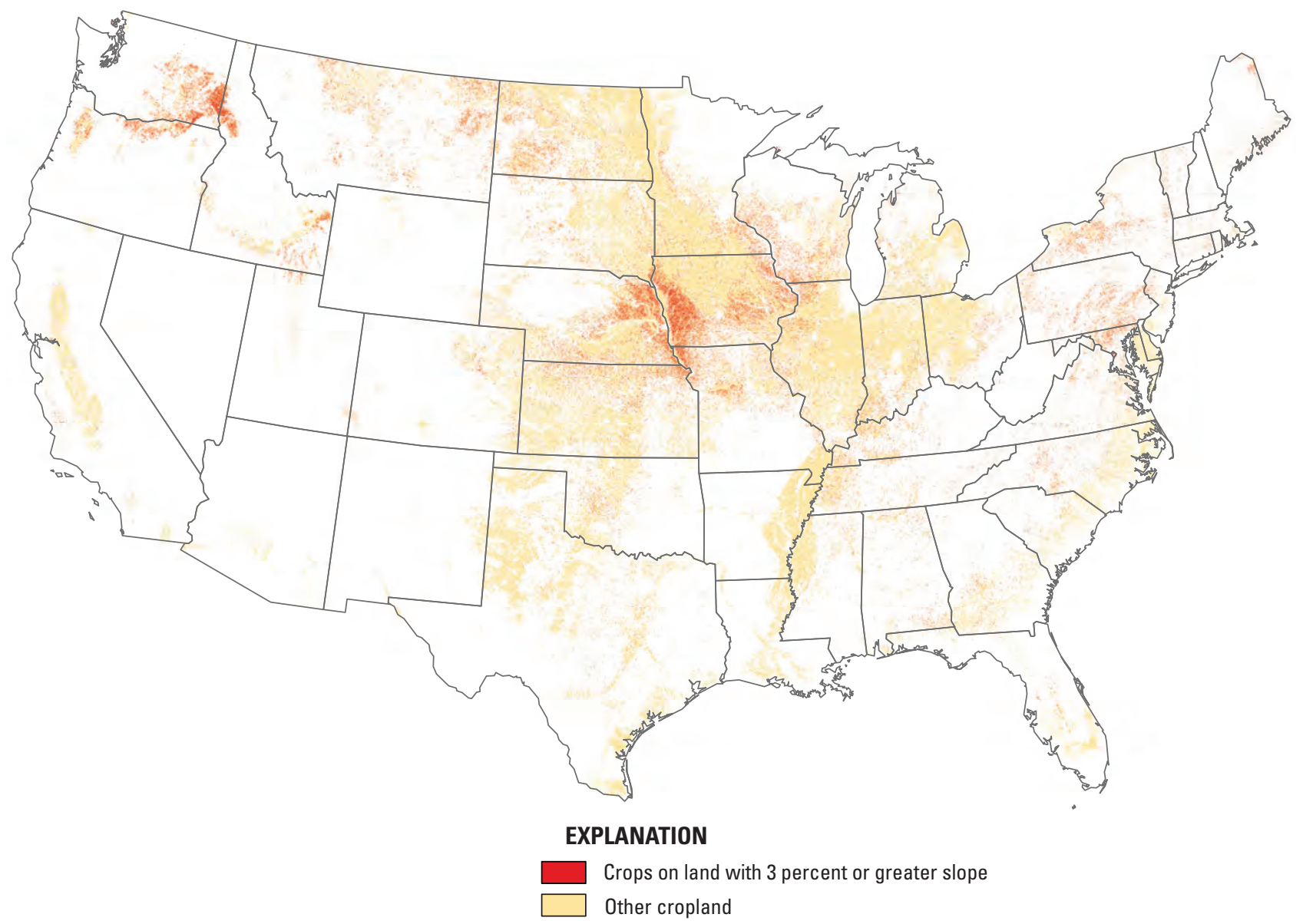

Figure 8. Location of crops on land with 3 percent or greater slope and location of other cropland in the conterminous United States (Falcone, 2003; U.S. Department of Agriculture, 2010b). 


\section{Climate}

Climate is an important factor for determining the location of crops, and it accounts for much of the regional differences in the types of crops grown across the Nation. The climate of a location is a function of precipitation and sunlight (solar radiation that determines light intensity and temperature). Climate is largely determined by latitude, altitude, and proximity to ice, snow cover, or water bodies.

The intensity, quantity, and duration of solar radiation that falls on the Earth at any given place determine local temperature and light. Light and heat are essential for the formation of chlorophyll and for the process of photosynthesis in plants. Different plants have different requirements for the amount of light and heat needed to reach maturity. For many plants, the growth rate from emergence to maturity depends upon the accumulation of specific quantities of heat. Cumulative growing degree-days (GDD) (or heat units), the metric used for the solar radiation requirements for crops, are the accumulated product of time and temperature above the minimum developmental thresholds for each day. Each plant has its own low-temperature threshold for development. One degree-day for a specific crop is one 24-hour period with an air temperature 1 degree $\left({ }^{\circ} \mathrm{F}\right)$ above the lower developmental threshold. For instance, the low temperature threshold for corn is $50^{\circ} \mathrm{F}^{1}$ (Wiebold, 2000). When the air temperature remains $52^{\circ} \mathrm{F}$ (or $2^{\circ}$ above the threshold) for 24 hours, 2 degree-days are accumulated. Growth of many crops pauses when the air temperature exceeds a certain level; therefore, cumulative

\footnotetext{
${ }^{1} 50^{\circ} \mathrm{F}$ is the most common base GDD for crops in the United States. GDDs may be calculating using either Celsius or Fahrenheit $\left(5 \mathrm{GDD}^{\mathrm{C}}=9 \mathrm{GDD}^{\mathrm{F}}\right)$.
}

GDDs do not capture the complete effect of temperature on growth. In addition, crops such as apples, grapes, and winter wheat require a period of cold dormancy before seeds or fruit can develop. Spring-seeded annual crops such as corn, soybeans, and rice do not require a period of cold dormancy.

The spatial distribution of major crops compared to cumulative GDD is shown in figure 9. More than 90 percent of all crops are grown in areas with more than 2,000 cumulative GDD (fig. 9) (appendix 4, table 4-1). All cotton, rice, and citrus require more than 4,000 cumulative GDD. On the other hand, many vegetables and ground fruit are grown in areas with less than 3,000 cumulative GDD.

Plants take water from the soil. In natural landscapes, soil water largely comes from precipitation that has infiltrated into the soil. The quantity of precipitation that falls on any given location has a strong influence on what kinds of plants thrive. Different plants have different requirements for the amount of water they need to develop to maturity. The amount of water that is needed for the same plant can be different because of air temperature and humidity throughout the growing season. The distribution of precipitation compared to cropland is shown in figure 10. It is evident from this figure that crop agriculture occurs in areas that have very low precipitation. Over 60 percent of all crops are grown in areas that receive less than $900 \mathrm{~mm} / \mathrm{yr}$ (appendix 4, table 4-2). Rice and citrus tend to be grown in areas with more precipitation, whereas wheat, sorghum, vegetables and ground fruit, and orchard and vineyard crops are grown in areas with less precipitation (fig. 10). 

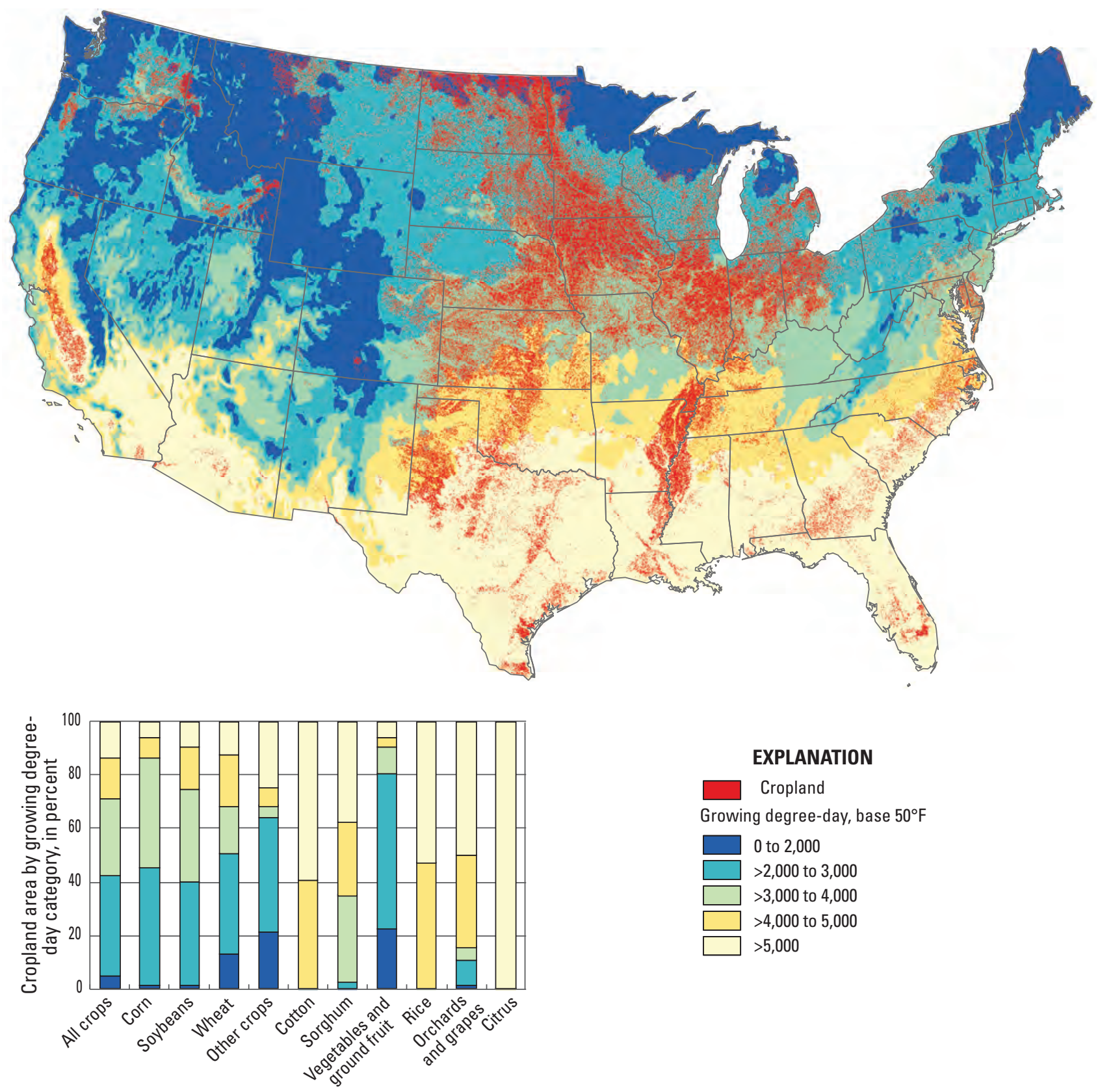

EXPLANATION

Cropland

Growing degree-day, base $50^{\circ} \mathrm{F}$

0 to 2,000

$>2,000$ to 3,000

$>3,000$ to 4,000

$>4,000$ to 5,000

$>5,000$

Figure 9. Location of cropland and average growing degree-days for base $50^{\circ} \mathrm{F}(1971-2000)$ and the percentage of cropland area for each growing degree-day category for selected crops in the conterminous United States (Oregon State University, 2010; U.S. Department of Agriculture, 2010b). 

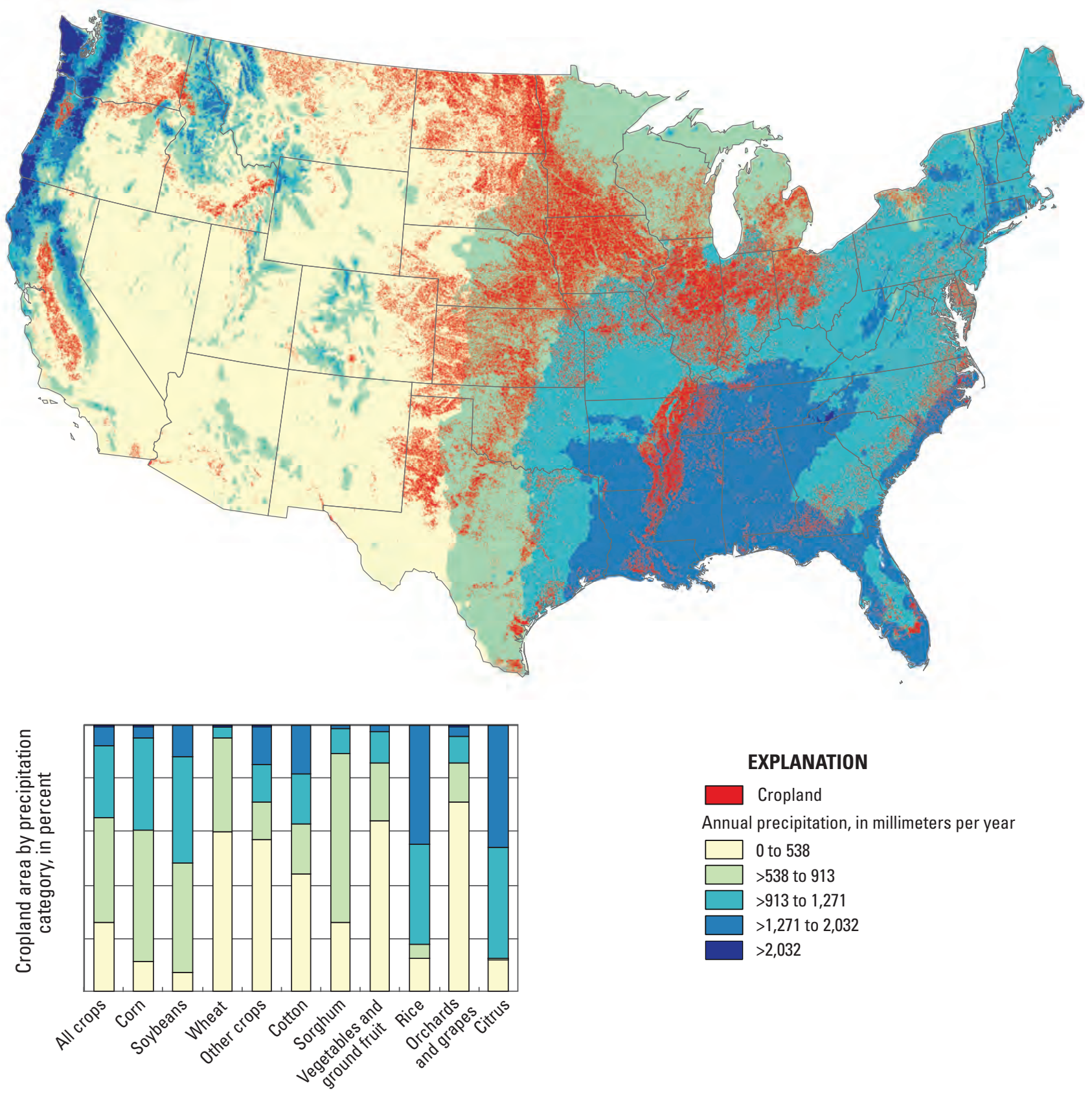

EXPLANATION

Cropland

Annual precipitation, in millimeters per year

$\square$ to 538

$>538$ to 913

$>913$ to 1,271

$>1,271$ to 2,032

$>2,032$

Figure 10. Location of cropland and average annual precipitation (1971-2000) and the percentage of cropland area for each precipitation category for selected crops in the conterminous United States (Oregon State University, 2008; U.S. Department of Agriculture, 2010b). 
The combined effect of the two climate factors, precipitation and temperature (solar radiation), on the favorable growing of various major crops can be seen in figure 11, which presents a range of favorable growing conditions, where optimal is the upper threshold temperature and precipitation requirement for most cultivars of each crop and sub-optimal is the lower threshold requirement for each crop. Optimal and sub-optimal thresholds for selected crops are documented by Fischer and others (2008) for temperature and by Brouwer and Heibloem (1986) for precipitation and are given in appendix 4, table 4-3. Crops raised under sub-optimal conditions will grow, but yields may be lower than crops raised under optimal conditions. Wheat is a versatile crop and can be grown in a variety of climates. The heat and moisture requirement thresholds are lower than for other major crops. Sorghum can tolerate drier climates, but it is not as cold hardy as many wheat varieties. Sorghum is often dryland farmed and is grown in areas where corn - a more profitable crop-will not thrive. Corn and soybeans are well adapted to the climate of the Midwest. In contrast, citrus has very high heat and moisturerequirement thresholds and can be grown only in selected areas of the country. Rice and cotton can be grown at similar temperature ranges, but rice growing is constrained by higher water requirements. A wide range of cultivars is available for most crops, and many cultivars are developed specifically to produce good yields in less than ideal conditions, such as a short growing season or dry conditions. Crops grown in arid areas outside the optimal crop area usually require irrigation to thrive.

Livestock are usually not as constrained by climate as plants are, and livestock are often grazed on lands that have too short a growing season or are too dry to profitably support cultivated crops. Grasses used for hay can be grown on these marginal lands, providing food for livestock during winter. Most of the rangelands in the United States extend westward from the wheat belt from Canada to Mexico.

In many parts of the Nation, the amount and timing of precipitation is sufficient to meet crop needs. In some areas, the overall annual precipitation is sufficient to meet crop growth requirements, but rainfall does not occur at the time it is needed; therefore, irrigation is used to supply water that has accumulated during the year and is stored as groundwater or in reservoirs (fig. 12).

Crops that are most likely to be irrigated are rice, nuts, citrus, other tree fruits, and grapes (fig. 13). All rice grown in the United States is produced in irrigated fields (U.S. Department of Agriculture, 2009c). Although about 15 percent of corn and 10 percent of soybeans are irrigated, these two crops account for $79,000 \mathrm{~km}^{2}$ of irrigated cropland. The extent of irrigated cropland for selected crops is shown in figure 13.

In areas where annual precipitation does not meet the crop water requirements, precipitation is supplemented by irrigation with water from another part of the same watershed (often stored as snow at high elevations), water from a different watershed, or mined groundwater. Mined groundwater is water that has accumulated in an aquifer over several years. Generally, the area where the aquifer is recharged is distant from its point of use for irrigation.

For example, California's Central Valley has ideal temperature and sunlight conditions for a wide variety of crops but has low annual precipitation in the valley itself. The mountainous regions to the east receive abundant precipitation in the form of snow; and, as the snow melts during the spring, it supplies water to the valley. In contrast, interbasin transfers of water are often used in the Northwestern States.

Irrigation is extensively used in the Great Plains. This water is more likely to be mined where more water is used on crops than is supplied by annual precipitation. The result is a lowering of the water table and a decrease in streamflow. Irrigation is also extensively used along the Mississippi River Valley. This area receives ample annual precipitation and, in the past, irrigation was a method of applying water to crops when needed by using water that was replenished every year. However, in recent years, intensive cropping practices have required more water than is replenished every year; the result has been a lowering of the water table in the area (fig. 14). Figure 14 shows areas of the Nation, including cropland, where groundwater levels have declined by more than $12 \mathrm{~m}$ (Reilly and others, 2008). 

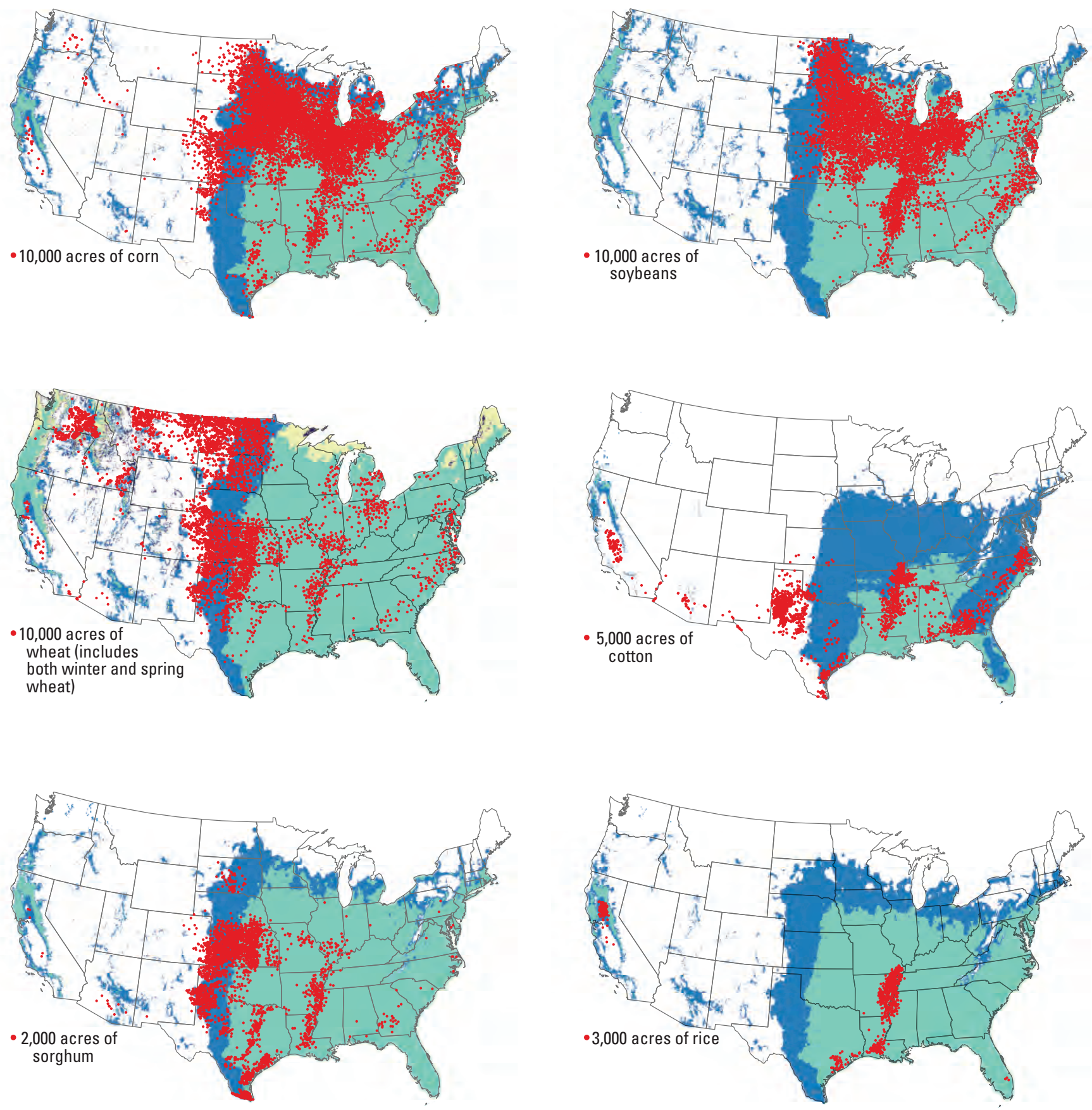

\section{EXPLANATION}

Minimum threshold for water and heat (growing degree days) requirements

Optimal

Optimal; additonal extent for winter wheat

Sub-optimal

Sub-optimal; additional extent for winter wheat

Climate is not favorable for selected crop

Figure 11. Extent of favorable climate for growing selected crops based on average annual growing degree-days and precipitation (1970-2001) and location of selected crops for the conterminous United States (Oregon State University, 2008 and 2010; U.S. Department of Agriculture, 2009a). 


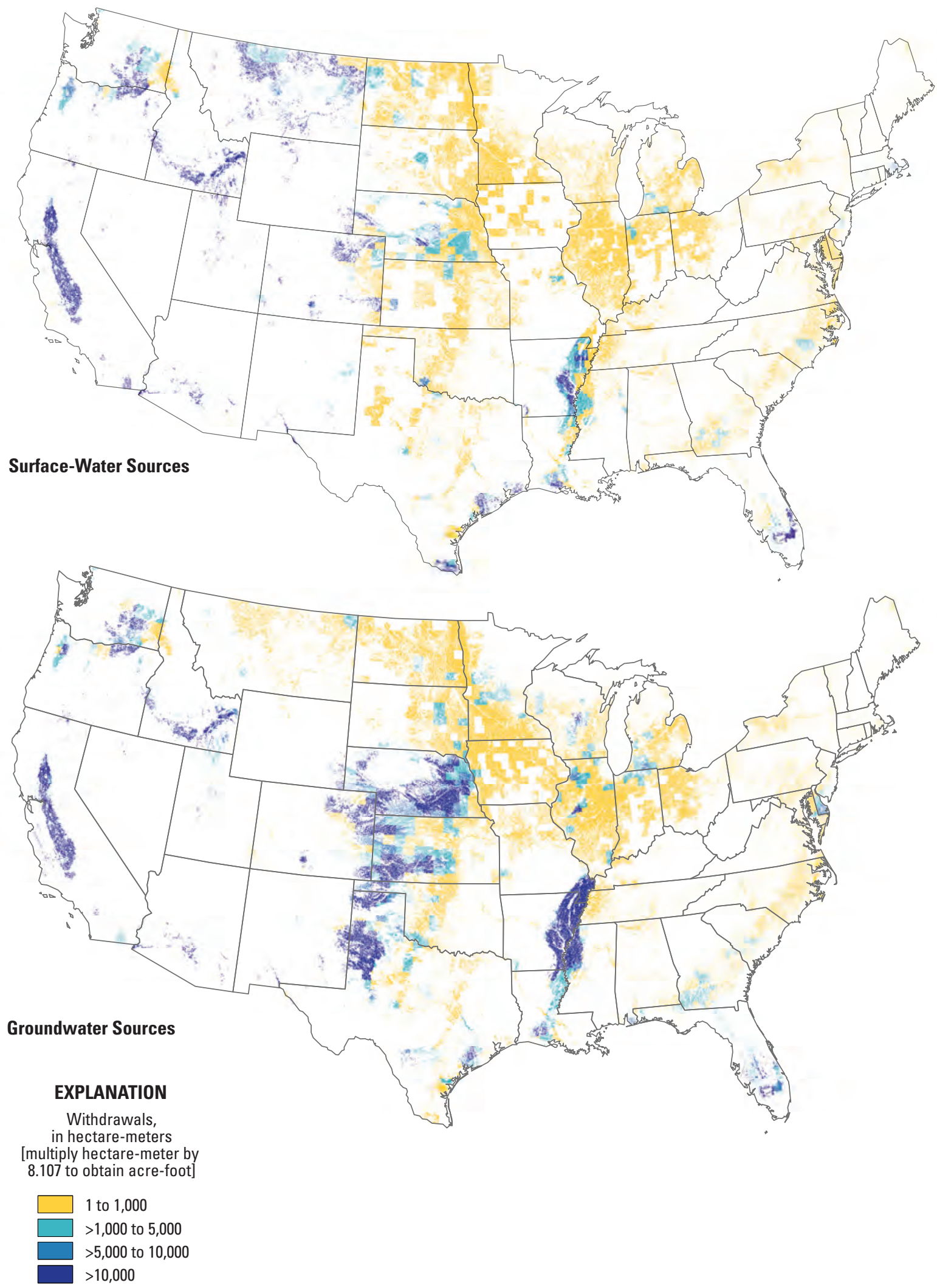

Figure 12. Extent of irrigated cropland from surface-water and groundwater sources in the conterminous United States (Kenny and others, 2009; U.S. Department of Agriculture, 2010b). 

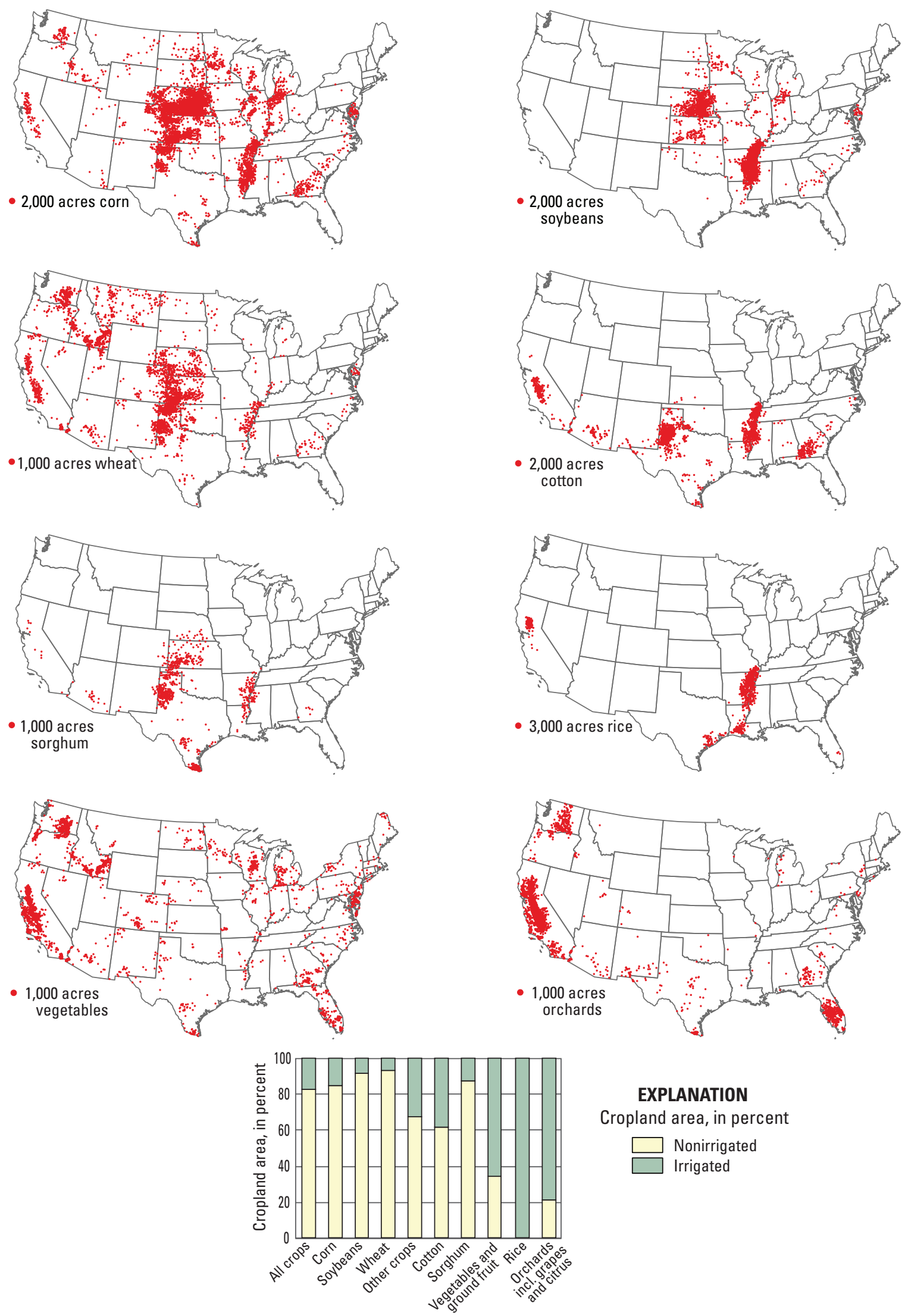

EXPLANATION

Cropland area, in percent

Nonirrigated

Irrigated

Figure 13. Extent of irrigated cropland and percentage of harvested cropland that is irrigated for selected crops in the conterminous United States, 2007 (U.S. Department of Agriculture, 2009a). 


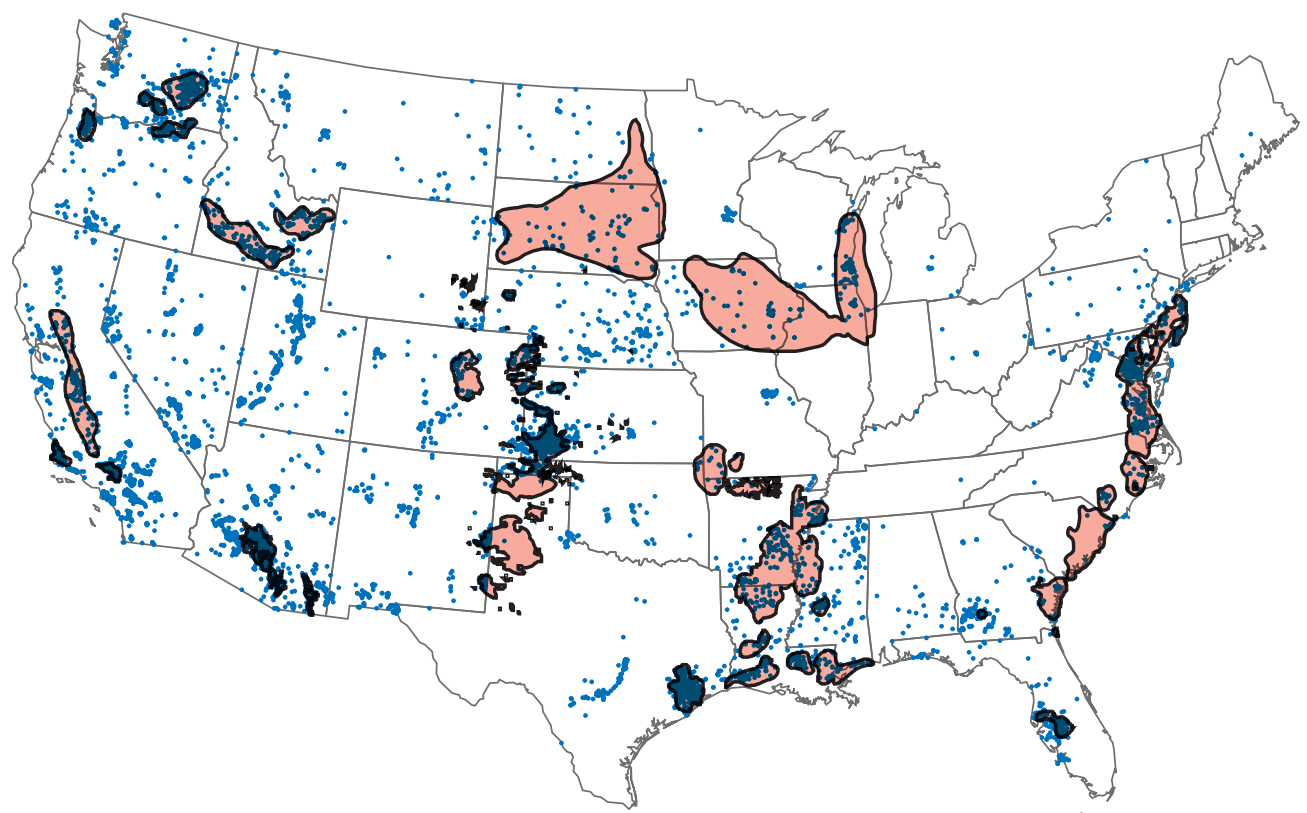

Areas in excess of 1,000 square kilometers that have groundwater-level decline in excess of 12 meters in at least one confined aquifer since predevelopment, or in excess of 7.5 meters of decline in unconfined aquifers since predevelopment.

- Wells in the U.S. Geological Survey National Water Information System database where the measured groundwater-level difference over time is greater than 12 meters.

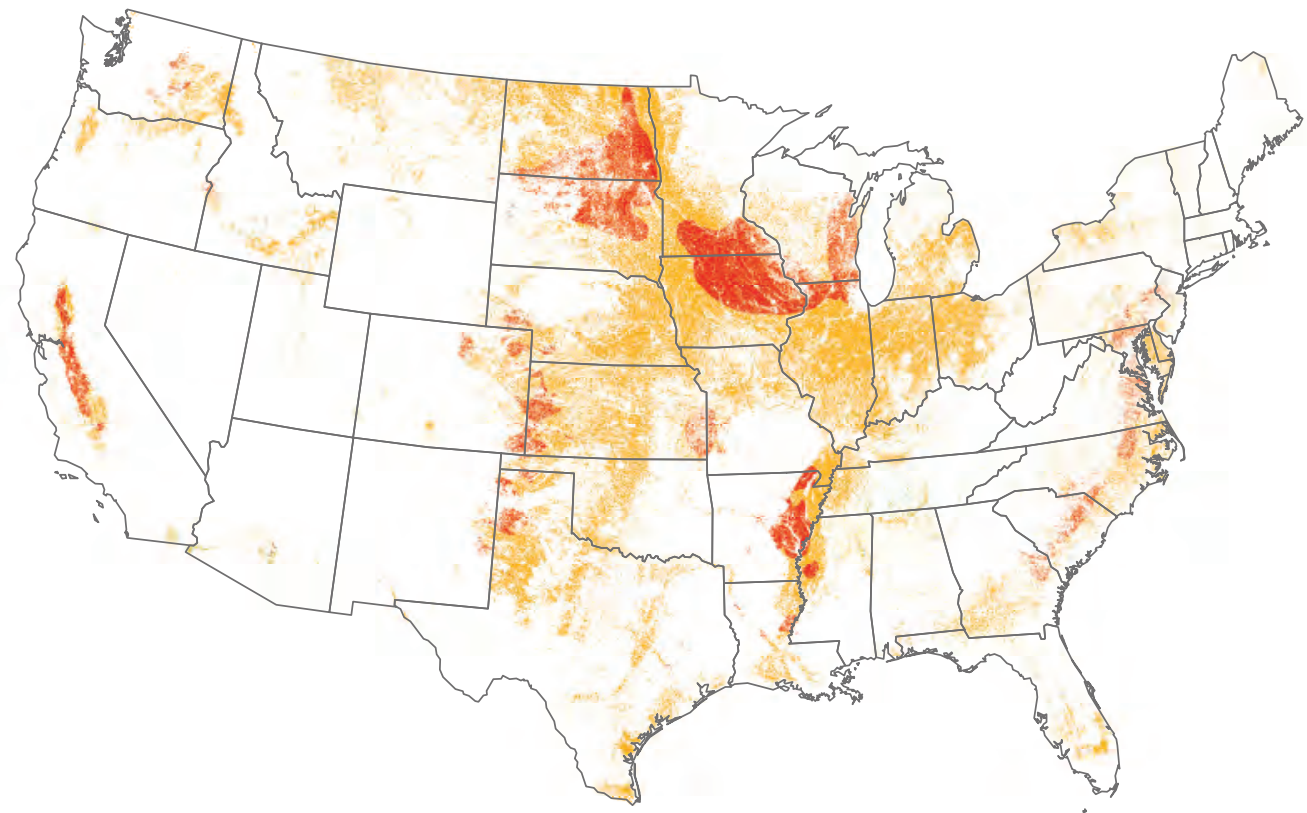

Cropland in areas that have groundwater-level decline

Other cropland

Figure 14. Areas of groundwater-level decline (Reilly and others, 2008) and the extent of cropland in areas that have groundwater-level decline in the conterminous United States (U.S. Department of Agriculture, 2010b). The areas of cropland that have groundwater-level decline do not necessarily mean that irrigated agriculture is the cause of the decline but rather that crops which rely on water from sources in decline may be vulnerable. 


\section{Soil}

Soils provide the physical base for crop roots and are the principal source of nutrients. Soils are formed by a combination of the weathering of rock (source of the mineral components) and the decomposition of vegetation (source of the organic-matter components). The degree to which vegetation can thrive in a soil is determined by a variety of soil properties: depth, texture (grain-size distribution), organic-matter content, fertility (nutrient level), mineralogy, and degree of weathering. Although soils in areas such as dunes, shifting sands, salt flats, rock debris, desert detritus, and glaciers and snow caps are either nonexistent or unsuitable for growing crops, most areas in the United States have soils where commercial agriculture is possible. Many soils require amendments to provide optimal growing conditions for plants.

Soil depth is not a limitation for crops in most locations. Most crops need at least 100 centimeters of soil to grow, although some crops can be grown in shallower soils (Fischer and others, 2002). The availability of water may be more of a constraint in shallow soils than lack of media for roots. Sadras and Calviño (2001) found that grain yield for wheat, corn, and soybeans was reduced in soils less than $120 \mathrm{~cm}$ but that the limiting factor was water deficit due to the shallow soils. Shallow soils underlain by bedrock or hardpan are highly erodible. Most of these soils are on steep slopes.

Soil texture is determined by the combined proportions of sand, silt, and clay. Texture, together with organic-matter content, influences the water-holding capacity and erodibility of a soil and allows aeration of plant roots. Sandy soils allow water to move more freely than through clay soils do, and they promote greater root aeration than clay soils do. However, clay soils have a greater water-holding capacity than sandy soils. Soils with a high percentage of silt and clay particles are more erodible than sandy soils under the same conditions. Differences in soil texture also affect organic-matter content; organic matter breaks down faster in sandy soils than in fine-textured soils (Berry and others, 2007). Although it is not practical to change soil texture, agricultural modifications can be implemented to make soils more favorable for growing crops. The organic-matter content can be increased by adding manure or by leaving crop residue on the surface. Soils with high waterholding capacities (high clay and (or) high organic-matter content) can be artificially drained to allow for proper root development. Terraces can be constructed on highly erodible soils to reduce soil erosion.

"Soil fertility" refers to the potential capacity of the soil to support plant growth based on its content of nitrogen and other nutrients. Some essential nutrients, such as nitrogen, phosphorus and potassium, are needed in relatively large quantities by plants; other essential nutrients (micronutrients), such as selenium and boron, are needed in much smaller quantities. More than 65 percent of all cropland (including hay) is supplemented with commercial fertilizer, lime, and soil conditioners (fig. 15). Most agricultural crops in the United States are supplemented with nitrogen, phosphorus, and (or) potassium (via potash fertilizer) to improve soil fertility and, ultimately, crop yield. Less than 20 percent of soybeans are treated with commercial nitrogen products, whereas nearly 100 percent of corn and more than 80 percent of wheat and cotton are treated with commercial nitrogen products (fig. 15).

The mineralogy of the soil particles, together with organic-matter content, determines soil chemical characteristics such as $\mathrm{pH}$, salinity, and cation exchange capacity. The $\mathrm{pH}$ strongly influences the degree to which phosphorous is available for plant uptake and, thus, influences soil fertility. The $\mathrm{pH}$ in soils is often increased (that is, the soil is made less acidic) by applying lime (powdered limestone). Some minerals form soils that are highly saline and high in sodium or gypsum content, a combination that impedes water infiltration and retards or prohibits plant growth. Clay minerals in soils strongly absorb cations such as calcium, magnesium, and sodium. The absorption quality of soils strongly influences soil cohesion, crust formation at the soil surface, and rate at which water infiltrates the soil. 

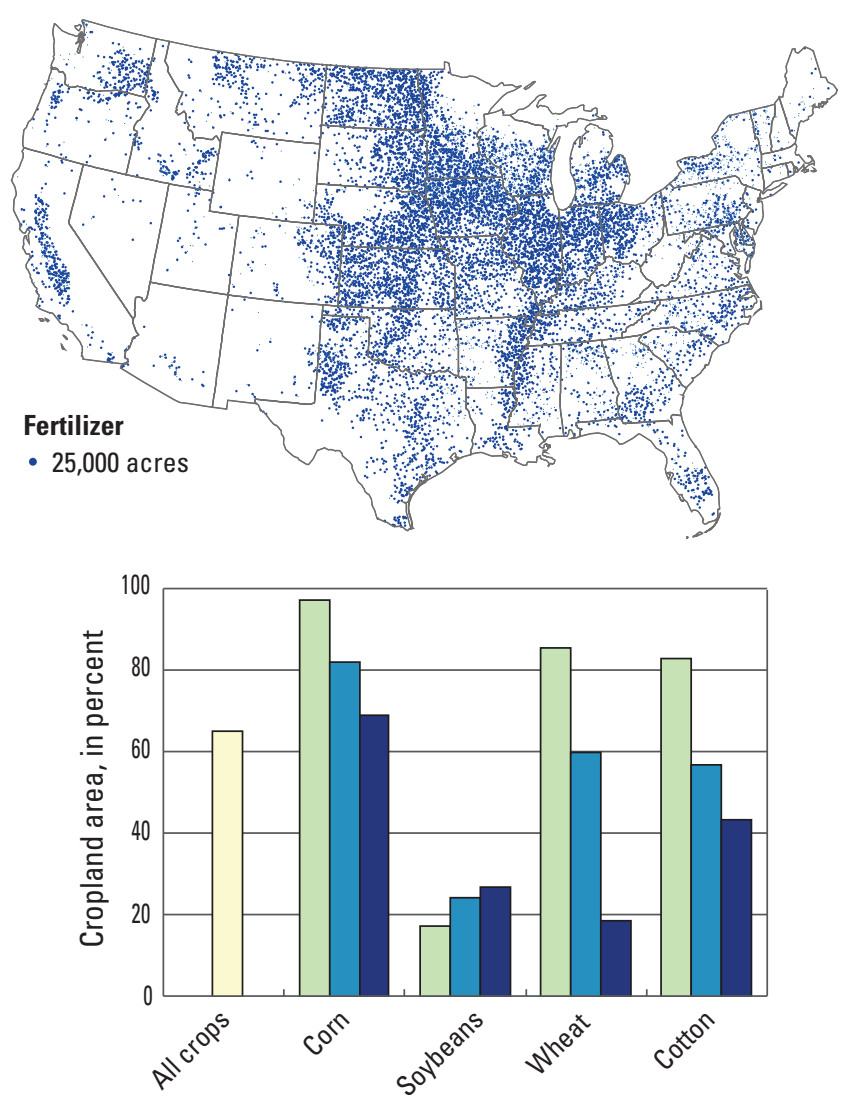

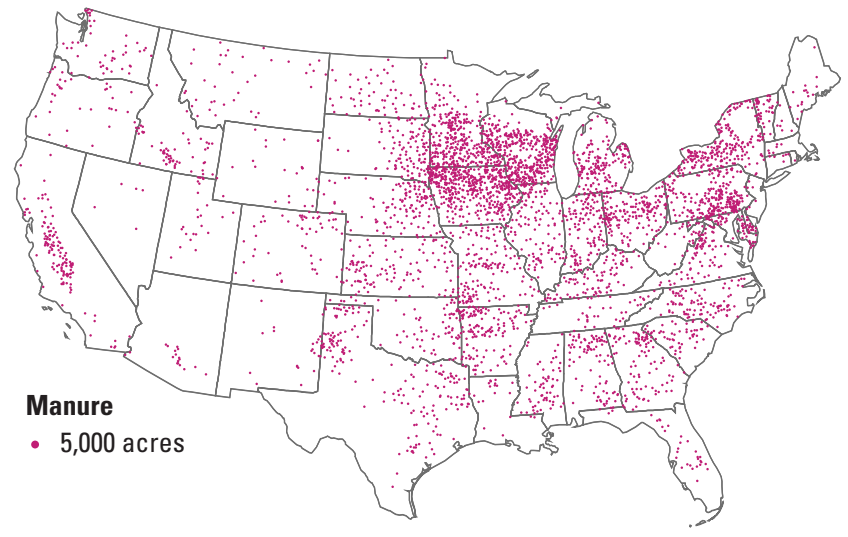

EXPLANATION

Bar graph

$\square$ All commercial fertilizers, lime, and soil conditioners
Nitrogen
Phosphate
Potash

Figure 15. Distribution of cropland treated with commercial fertilizer, lime, and soil conditioners (266 million acres) and land treated with manure (22 million acres); and percentage of all cropland (including hay) treated with commercial fertilizer, lime, and soil conditioners and percentage of land treated with nitrogen, phosphorus, and potash for selected crops in the conterminous United States, 1989-2007 (U.S. Department of Agriculture, 2009b, 2010a). 
The U.S. Department of Agriculture classifies soils on the basis of their potential suitability for cropland without deterioration of the soil over time (capability classes). The system uses eight classes based on landscape location, slope, soil depth, texture, and chemical properties (Helms, 1992). The spatial distribution of the soil capability classes shows that most soils in the East and the Great Plains are suitable for cropland (classes I-IV), whereas most of the soils in the interior West are more suited to grazing land (classes V-VIII) (fig. 16). About 7 percent of all crops are grown on soils with slight limitations (class I) with unrestricted use for agriculture (appendix 5, table 5-1). Forty-seven percent of crops are grown on soils that have moderate limitations (class II) and may require conservation measures, 29 percent of crops are grown on soils that have severe limitations (class III) and require special conservation practices, and 10 percent of crops are grown on soils with very severe limitations (class IV) that restrict the choice of plants and require very careful
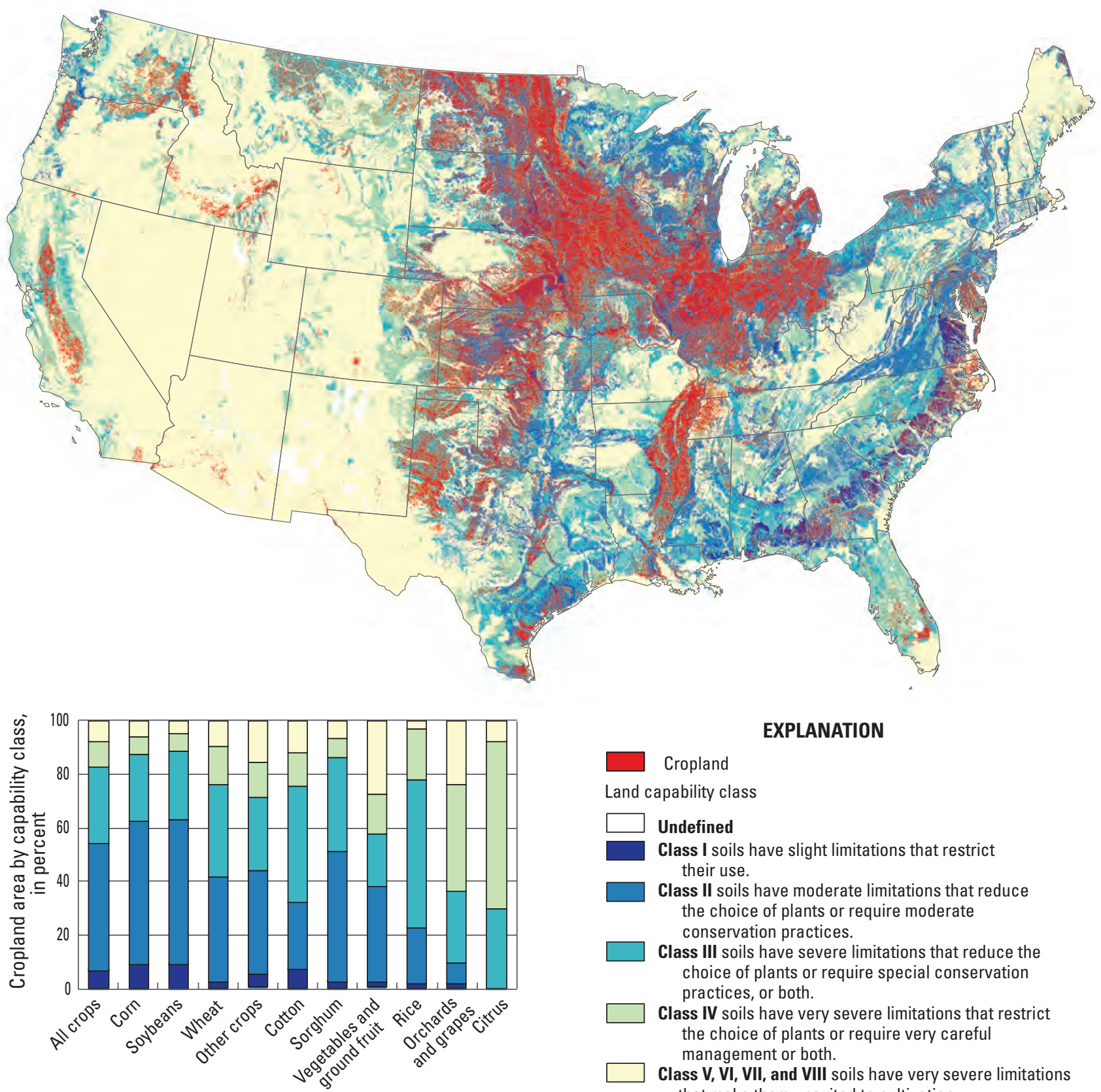

EXPLANATION

Cropland

Land capability class

$\square$ Undefined

Class I soils have slight limitations that restrict their use.

Class II soils have moderate limitations that reduce the choice of plants or require moderate conservation practices.

Class III soils have severe limitations that reduce the choice of plants or require special conservation practices, or both.

Class IV soils have very severe limitations that restrict the choice of plants or require very careful management or both.

Class V, VI, VII, and VIII soils have very severe limitations that make them unsuited to cultivation.

Figure 16. Location of cropland on each land capability class and the percentage of cropland area for each capability class for selected crops in the conterminous United States (U.S. Department of Agriculture, 2006, 2010b). 
management (fig. 16). About 11 percent of crops are grown on soils considered unsuitable for cultivation (classes V-VIII). In some instances when class V-VIII soils are irrigated, the limitations for agricultural use are reduced. Still, many soils in the arid West are characterized by limitations such as shallowness, stoniness, low moisture-holding capacity, low fertility, and salinity that are difficult to correct. Over half of all tree nuts and fruits, as well as grapes, are grown on class IV or less suitable soils. These crops do not require continued cultivation and are more likely to thrive in these soils than annual crops. Wheat, cotton, vegetables, rice and citrus are more likely to be grown on poorer soils than corn and soybeans. Figure 17 shows the location of cropland on soils that have severe or very severe limitations and may require special conservation or management practices.

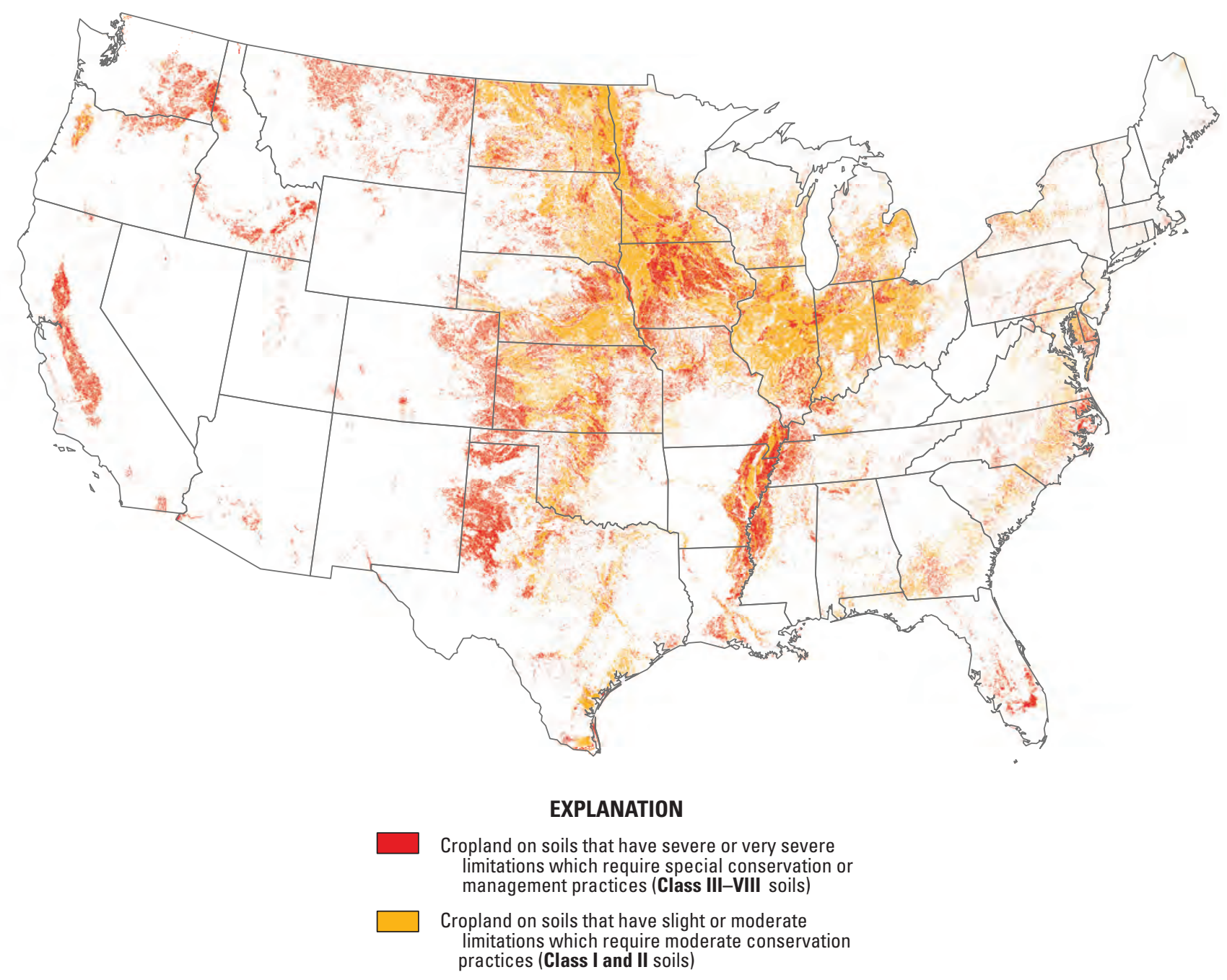

Figure 17. Location of cropland on soils that have severe or very severe limitations which require special conservation or management practices (Class III-VIII soils) and cropland on soils that have slight or moderate limitations which require moderate conservation practices (Class I and II soils) in the conterminous United States (U.S. Department of Agriculture, 2006, 2010b). 


\section{Soil Water}

The amount of water in soil that is available to plants is controlled by terrain, climate, and soil characteristics. Soilwater availability is the limiting factor for the location of crop agriculture in many areas. The water in soil comes largely from precipitation. In some locations, soil water can also come via groundwater or surface-water flowpaths. Crop agriculture is highly dependent upon the amount and seasonal patterns of available soil water from precipitation and, in many areas, irrigation. Animal agriculture is not directly dependent on soil water, but it is dependent on the quantity and quality of groundwater and (or) surface water that is available.

In addition to its soil capability classification system, the U.S. Department of Agriculture has a soil classification based on the dominant hazard that affects use of the soil for agriculture (fig. 18) (Helms, 1992). The dominant hazard can be climate, soil, erosion, or excess water. Susceptibility to soil erosion from water runoff (or wind) is the dominant hazard that affects the use of most soils in the Nation. Fifty-one percent of crops are grown on soils where erosion susceptibility and past erosion damage are the major factors affecting these soils (appendix 6, table 6-1). Twenty-five percent of crops are grown on soils where poor drainage, wetness, high water table, or overland flow is the dominant hazard. Most of the rice and citrus grown in this country are grown on soils where water is the dominant hazard. Many of the soils along the Gulf Coast and East Coast and along the river valleys are limited by their excess water content. These soils can be artificially drained to overcome such limitations. Figure 19 shows the location of cropland on soils in each hazard class (climate, erosion, soils, and water).

It is important that excessive soil water does not occur at times detrimental to plant growth and harvest. The occurrence of moisture stress during flowering, pollination, and grain-filling is harmful to most crops and particularly to corn, soybeans, and wheat. Excessive soil water interferes with plant nutrient flow, increases the risk of plant disease and insect infestation, and delays to planting or harvesting. In addition, the necessity and feasibility of irrigation are determined by the degree of evapotranspiration and the distribution of precipitation through the growing season. 

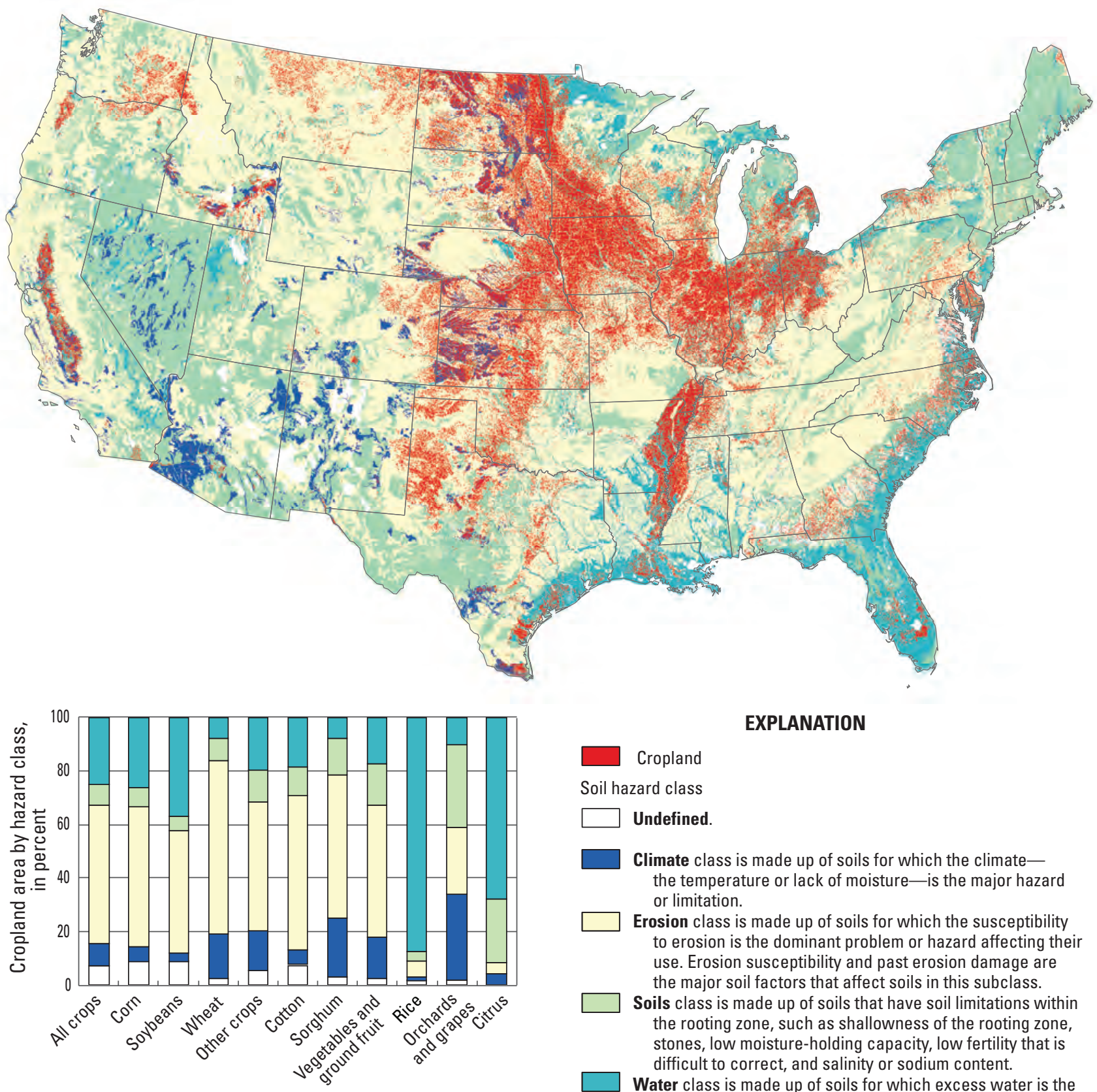

EXPLANATION

Cropland

Soil hazard class

\section{Undefined.}

Climate class is made up of soils for which the climatethe temperature or lack of moisture-is the major hazard or limitation.

Erosion class is made up of soils for which the susceptibility to erosion is the dominant problem or hazard affecting their use. Erosion susceptibility and past erosion damage are the major soil factors that affect soils in this subclass.

Soils class is made up of soils that have soil limitations within the rooting zone, such as shallowness of the rooting zone, stones, low moisture-holding capacity, low fertility that is difficult to correct, and salinity or sodium content.

Water class is made up of soils for which excess water is the dominant hazard or limitation affecting their use. Poor soil drainage, wetness, a high water table, and overflow are factors that affect these soils.

Figure 18. Location of cropland on each soil hazard class and the percentage of cropland area for each soil hazard class for selected crops in the conterminous United States (U.S. Department of Agriculture, 2006, 2010b). 
Some of the most fertile cropland is in areas with too much water. Much of the Midwest and Eastern Piedmont were previously wetlands and are underlain by poorly drained soils (Dahl, 1990). The landscape has shallow slopes, and annual precipitation exceeds evapotranspiration. Much of the cropland in this area is drained so that fields are accessible for planting and roots are not damaged by too much water. It is estimated that 87 percent of wetland losses from the mid-1950s to mid-1970s were due to the installation of artificial drainage for conversion to agricultural land (Frayer and others, 1983). Artificial drainage includes both surface and subsurface modifications that remove excess water away from crops. Surface artificial drainage usually involves constructing ditches or straightening and deepening natural channels, and subsurface artificial drainage includes the installation of drainage pipes (often called tile drains) at some depth (1-2 m) below the land surface. Crops most likely to be grown in areas that are drained are corn, soybeans, and citrus (fig. 20) (appendix 6, table 6-2). Most of the rice grown in the United States is grown on poorly drained soils. In contrast to other crop environments, rice fields are allowed to remain flooded until harvest.

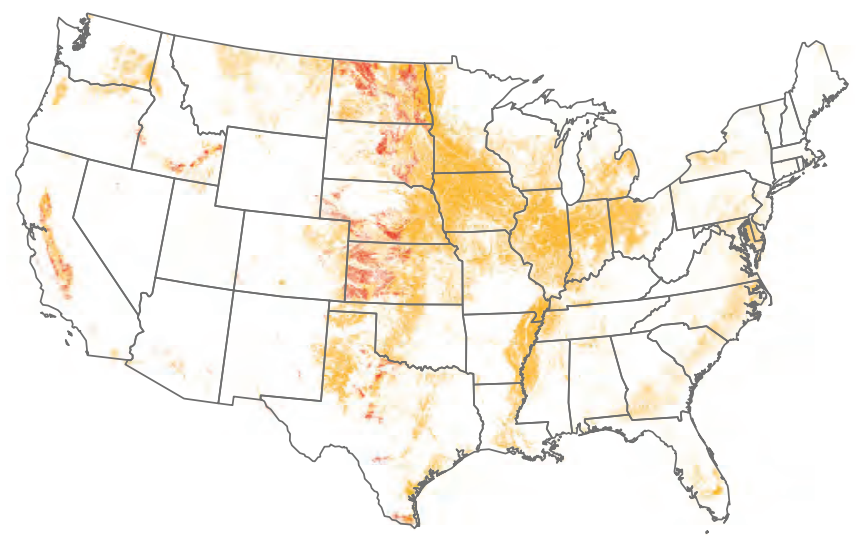

Climate

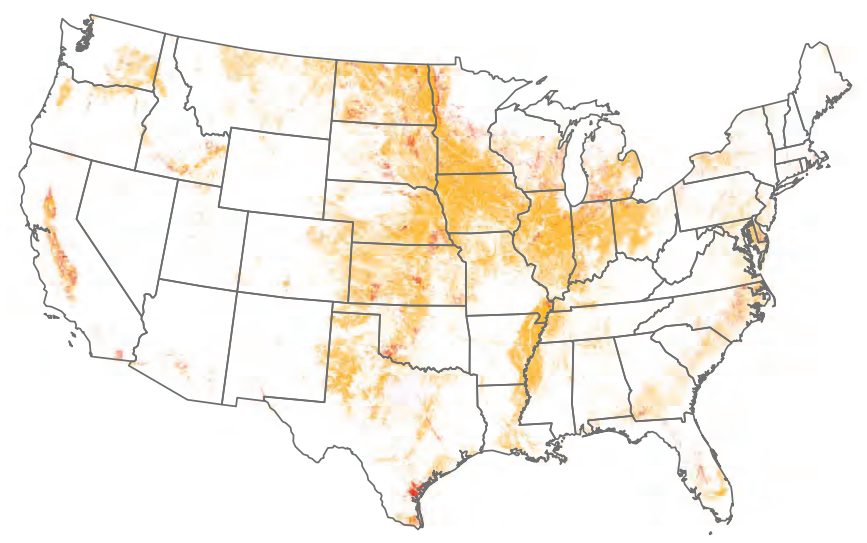

Soils

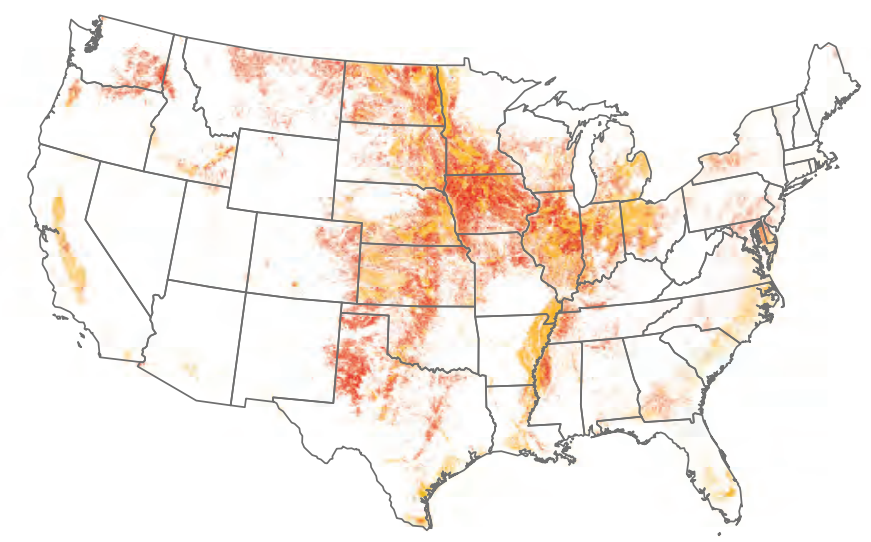

Erosion

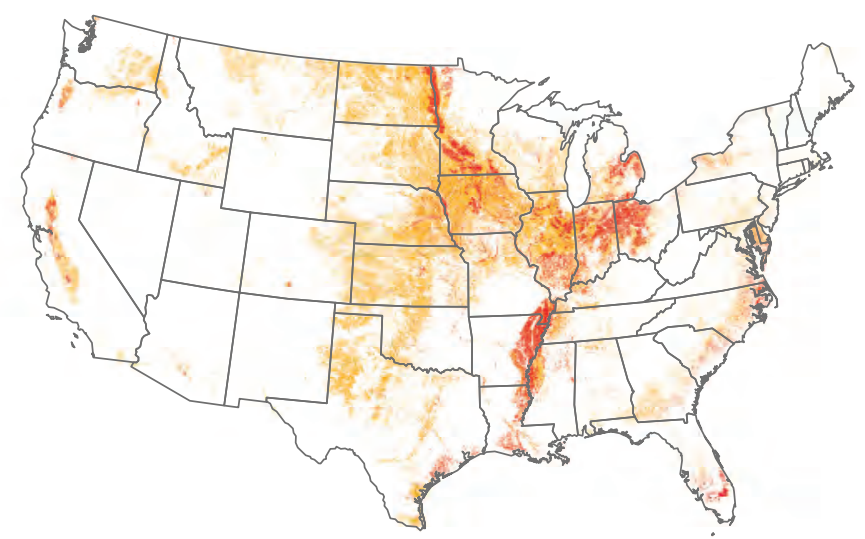

Water

\section{EXPLANATION}

Cropland on soils in selected hazard class

Other cropland

Figure 19. Location of cropland on soils in each hazard class (Climate, Erosion, Soils, and Water) in the conterminous United States (U.S. Department of Agriculture, 2006, 2010b). 

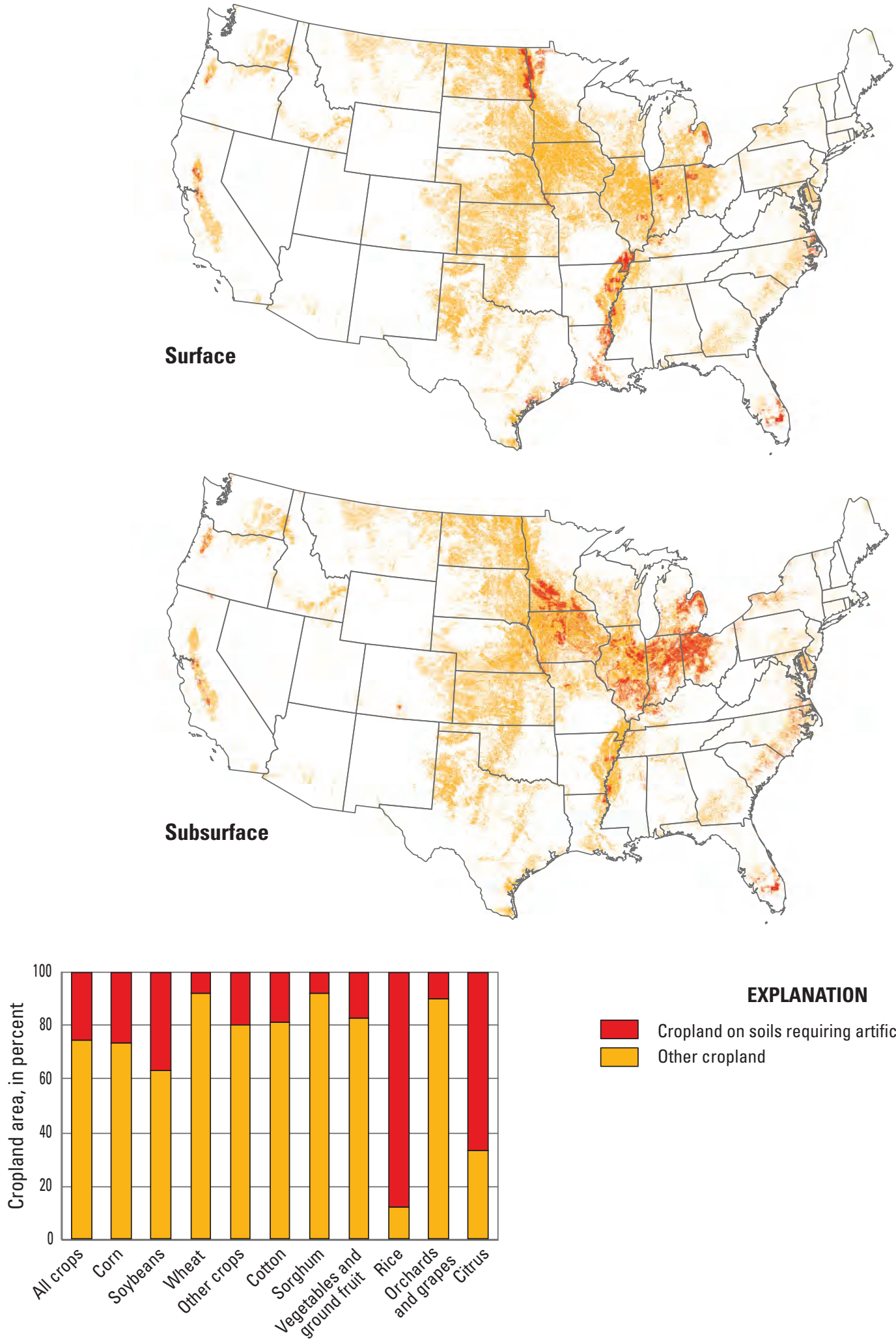

\section{EXPLANATION}

Cropland on soils requiring artificial drainage Other cropland

Figure 20. Cropland on soils where surface or subsurface artificial drainage is likely required to remove excess water in order to cultivate cropland in the conterminous United States (U.S. Department of Agriculture, 2006, 2010b; Michael E. Wieczorek, U.S. Geological Survey, written commun., 2010). Maps show areas where either surface or subsurface artificial drainage is predominant. 
Area runoff and recharge are the amount of water available for streamflow and seepage to groundwater. The sustained supply of water from surface and underground resources influences which crops can be grown in specific areas. Average annual runoff and recharge depth for a watershed is the combined runoff and recharge for a year uniformly distributed over the entire watershed and is an indication of the wetness or dryness of an area. Much of the wheat, cotton, sorghum, and citrus produced in the United States is grown in areas with less than $214 \mathrm{~mm}$ of annual runoff or recharge (figs. 21 and 22; appendix 6, tables 6-3 and 6-4). With the exception of citrus, most of these crops are grown in Great Plains States characterized by low to moderate slopes, evapotranspiration often exceeding precipitation, and soils with moderate or
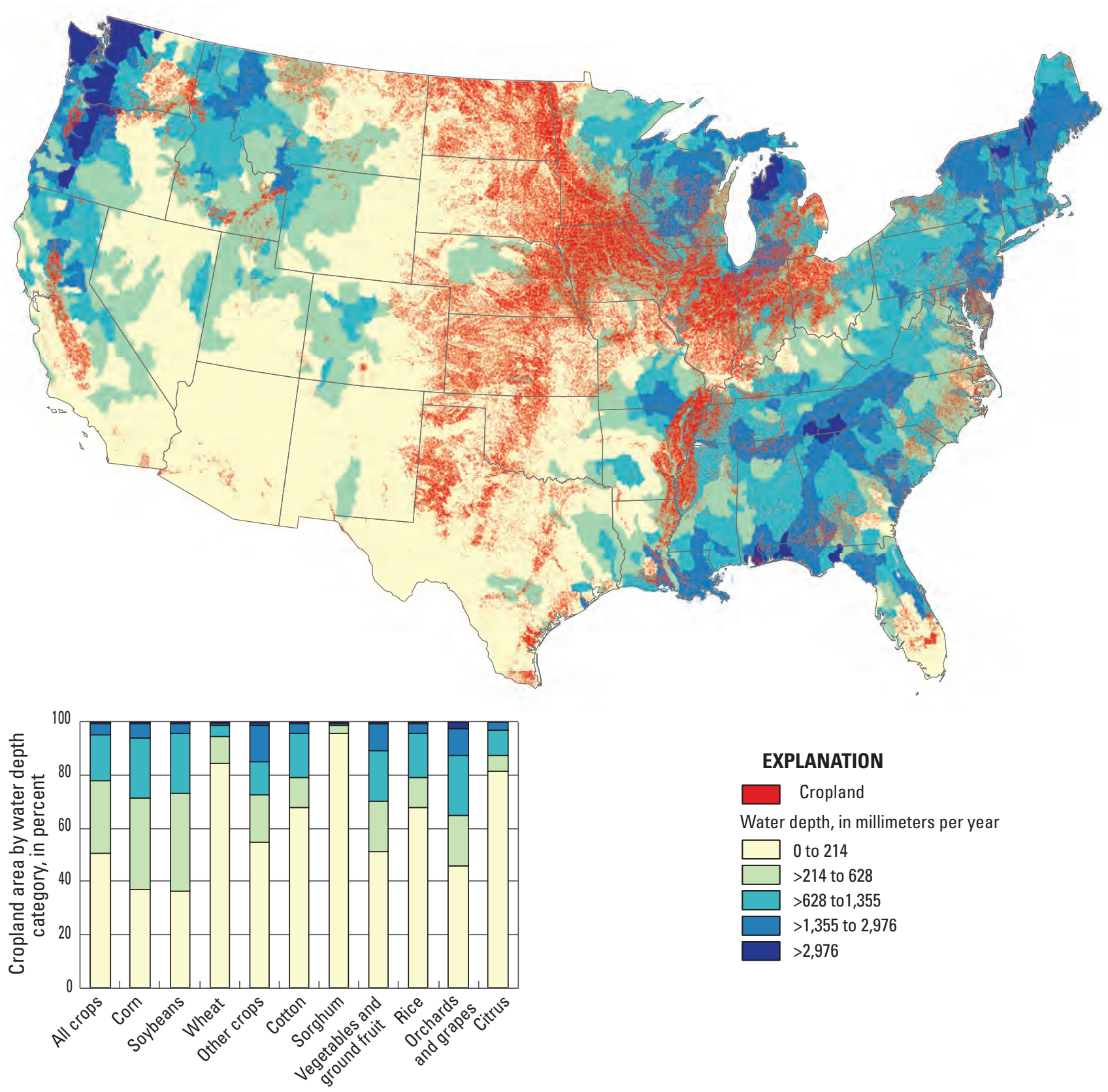

\section{EXPLANATION}

Cropland

Water depth, in millimeters per year

0 to 214

$>214$ to 628

$>628$ to 1,355

$>1,355$ to 2,976

$>2,976$

Figure 21. Location of cropland and average annual runoff (1971-2000) and the percentage of cropland area for each runoff category for selected crops in the conterminous United States (David M. Wolock, U.S. Geological Survey, written commun., 2009; U.S. Department of Agriculture, 2010b). 
severe limitations for cultivation. Many tree fruits are grown in areas with more than $628 \mathrm{~mm}$ annual runoff and recharge. The areas with the highest runoff and recharge, the Pacific Northwest, northern Michigan, and the Northeast, tend to have high precipitation, low evapotranspiration, steeper slopes, and sandy soils. These areas are particularly suited to tree fruit production. Areas with more moderate runoff and recharge are the Midwest and Southern Gulf States. Corn and soybeans are the predominant crops in these areas characterized by low slopes, adequate precipitation for evapotranspiration requirements, and soils with slight or moderate limitations for cultivation.
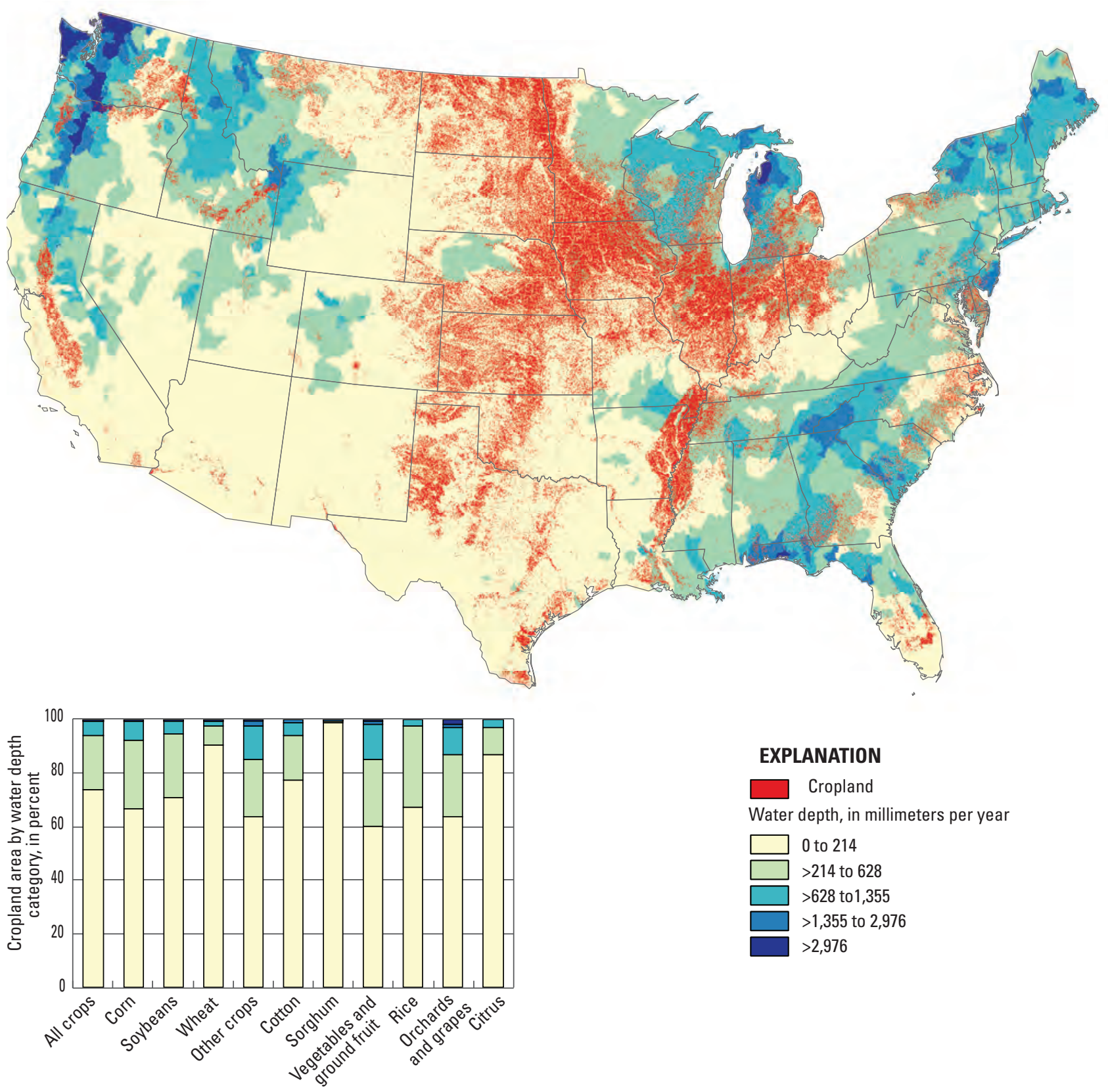

EXPLANATION

Cropland

Water depth, in millimeters per year

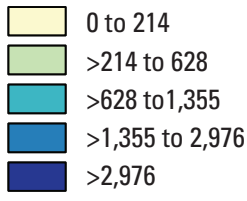

Figure 22. Location of cropland and average annual recharge (1971-2000) and the percentage of cropland area for each recharge category for selected crops in the conterminous United States (David M. Wolock, U.S. Geological Survey, written commun., 2009; U.S. Department of Agriculture, 2010b). 


\section{Other Land Uses in Competition for Agricultural Lands}

Crops need space to grow. Since the beginning of agriculture over 10,000 years ago, land has been cleared for the production of crops. Much of the Nation's forests, grasslands, and wetlands have been converted to agricultural land (fig. 23) (appendix 7, tables 7-1, 7-2 and 7-3). Nearly 25 percent of wetlands have been converted to cropland. A large percentage of land now devoted to rice ( 88 percent) and citrus (67 percent) was once natural wetlands (table 7-2). About 80 percent of land now devoted to wheat was once natural grasslands. In contrast, only a small percentage of needleleaf forests have been converted to cropland because needleleaf forests commonly grow in soils and on terrain less suitable for cropland.

Increasing population and land development during the last 100 years have increased the extent of urban use competing for agricultural land. Continuing population growth will cause further increases in urbanization, land development, and demand for agricultural products - the latter paradoxically resulting in an even greater need of space for agricultural land. The annual conversion of prime agricultural land to developed land in the United States amounts to about 2,600 km², nearly 30 percent of this conversion occurring in just four states: Texas $\left(271 \mathrm{~km}^{2}\right)$, Ohio $\left(170 \mathrm{~km}^{2}\right)$, North Carolina $\left(138 \mathrm{~km}^{2}\right)$ and Illinois $\left(129 \mathrm{~km}^{2}\right)$ (Abdalla, 2005).
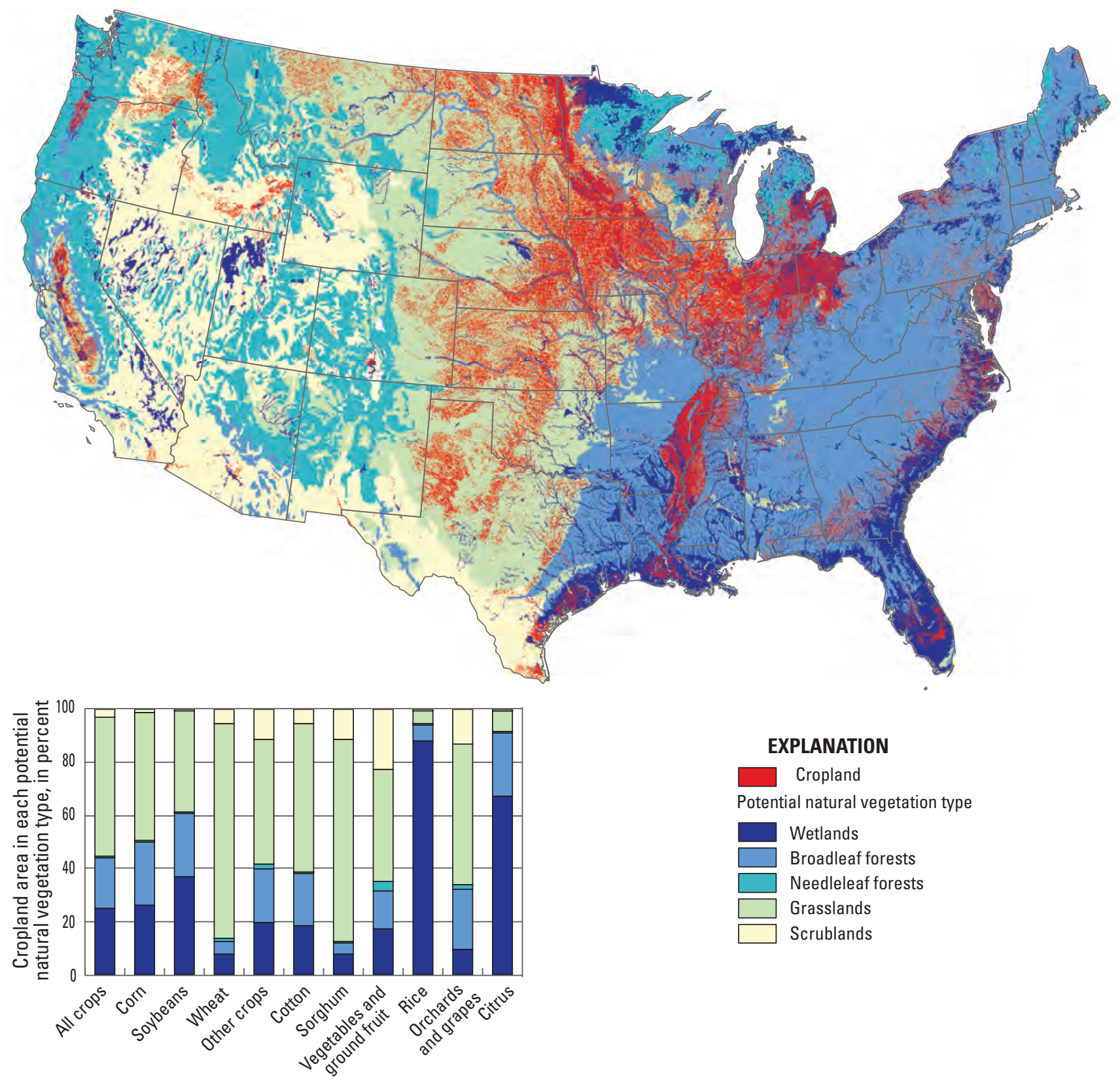

Figure 23. Location of cropland on potential natural vegetation, and the percentage of cropland area in each natural vegetation type for selected crops in the conterminous United States (Missoula Fire Sciences Laboratory, 2001; U.S. Department of Agriculture, 2010b). 


\section{Summary}

Environmental, economic, and societal factors have determined the location of crop agriculture. The environmental factors influencing the extent of crop agriculture are terrain, climate, soil properties, and soil water. It is the combination of these four environmental factors that create suitable conditions for specific crops to be grown in certain areas. In some locations, conditions are nearly ideal for commercial agriculture. In other locations - places with rugged slopes, poor soil, lack of soil water, excess soil water and (or) inhospitable climate - commercial agriculture is unprofitable, perhaps even impossible. However, most agricultural lands fall somewhere between the two ends of the spectrum. Today, in order to maximize production, most of the cultivated croplands and grasslands for commercial agriculture are in areas where crops and livestock are well suited to local conditions. In the United States, cropland (row crops, closely sown crops, fruits, nuts, and vegetables) occupies about 13 percent of the total land area. Grassland (including hay) and rangeland occupy another 41 percent of the land area.

In areas that are too steep, too wet, or too dry, modifications of the landscape have been implemented to make conditions suitable for crops to grow and thrive. Some of the limitations of the environmental influences can be overcome through agricultural modifications, but others cannot. On a larger-than-field scale, agricultural modifications commonly influence water availability through irrigation and (or) drainage and soil fertility and (or) organic-matter content through amendments such as manure, commercial fertilizer and lime. In general, it is not feasible to modify the other environmental influences - soil texture, soil depth, soil mineralogy, temperature, and terrain - at large scales.

About 1 percent of crops in the conterminous United States are grown at elevations higher than 2,000 m; wheat, "other crops" (including grasses such as rye, oats, and barley), and vegetables and ground fruit make up most of the crops grown at these high altitudes.

About 80 percent of all crops in the conterminous United States are grown on land with a slope of 3 percent or less. Nearly all cotton, rice, and citrus are grown on land with a slope of 2 percent or less. About 10 percent of all crops are grown on slopes greater than 4 percent, and only a small percentage of all crops are grown on steeper slopes (5 to
16 percent). The crops grown on steeper slopes are tree fruits, grapes, vegetables, and other grains. A much larger percentage of grassland has steeper slopes than cropland; in fact, about 22 percent of grassland is grown on slopes steeper than 5 percent, because steeper slopes are generally unsuited to cultivation.

Cumulative growing degree-days (GDD) (or heat units), the metric used for the solar radiation requirements for crops, are the accumulated product of time and temperature above the minimum developmental thresholds for each day. More than 90 percent of all crops in the conterminous United States are grown in areas with more than 2,000 cumulative GDD. All cotton, rice, and citrus require more than 4,000 cumulative GDD, but many vegetables and ground fruits are grown in areas with less than 3,000 cumulative GDD.

More than 60 percent of all crops in the conterminous United States are grown in areas that receive less than 900 $\mathrm{mm} / \mathrm{yr}$. Rice and citrus tend to be grown in areas with more precipitation, whereas wheat, sorghum, vegetables and ground fruit, and orchard and vineyard crops are grown in areas with less precipitation. Crops that are most likely to be irrigated are rice, nuts, citrus, other tree fruits, and grapes. All rice grown in the United States is produced in irrigated fields. Although about 15 percent of corn and 10 percent of soybeans are irrigated, these two crops account for $79,000 \mathrm{~km}^{2}$ of irrigated cropland.

With respect to U.S. Department of Agriculture soil capability classes, about 7 percent of all crops in the conterminous United States are grown on soils with slight limitations (class I) with unrestricted use for agriculture 47 percent of crops are grown on soils that have moderate limitations (class II) and may require conservation measures, 29 percent of crops are grown on soils that have severe limitations (class III) and require special conservation practices, and 10 percent of crops are grown on soils with very severe limitations (class IV) that restrict the choice of plants and require very careful management. About 11 percent of crops are grown on soils considered unsuitable for cultivation (classes V-VIII).

Increasing population and land development during the last 100 years have increased the extent of urban use competing for agricultural land. Continuing population growth will cause further increases in urbanization, land development, and demand for agricultural products - the latter paradoxically resulting in an even greater need of space for agricultural land. 


\section{References Cited}

Abdalla, C.W., 2005, Competition for land use-Agricultural/urban interface, in Pond, W.G., and Bell, A.W., eds., Encyclopedia of animal science: New York, Marcel Dekker, p. 232-234.

Berry, Wayne; Ketterings, Quirine; Antes, Steve; Page, Steve; Russell-Anelli, Jonathan; Rao, Renuka; and DeGloria, Steve, 2007, Soil texture: Cornell University, Cooperative Extension, Nutrient Management Spear Program, Agronomy Fact Sheet Series, Fact Sheet 29, 2 p., accessed September 2010 at http://nmsp.cals.cornell.edu/guidelines/ factsheets.html.

Birdsall, S.S., Florin, J.W., and Price, M.L., 1999, Regional landscapes of the United States and Canada (5th ed.): New York, John Wiley \& Sons, $450 \mathrm{p}$.

Brouwer, C., and Heibloem M., 1986, Irrigation water management-Training manual no. 3, Irrigation water needs: International Institute for Land Reclamation and Improvement and FAO Land and Water Development Division, accessed February 2011 at $h t t p: / / w w w$ fao.org/docrep/ s2022e/s2022e00.htm\#Contents.

Dahl, T.E., 1990, Wetlands losses in the United States 1780's to 1980's: Washington, D.C., U.S. Department of the Interior, Fish and Wildlife Service; and Jamestown, N. Dak., Northern Prairie Wildlife Research Center Online, accessed March 2011 at http://www.npwrc.usgs.gov/resource/ wetlands/wetloss/index.htm (Version 16JUL97).

Falcone, James, 2003, National elevation data, resampled to 100 m: Reston, Va., U.S. Geological Survey geospatial data, accessed October 2009 at ftp://ftpext.usgs.gov/pub/er/val reston/NAWQA_ENS/GIS_DATA/elevation/.

Fischer, Günther; van Velthuizen, Harrij; Sha, Mahendra; and Nachtergaele, Freddy, 2002, Global agro-ecological assessment for agriculture in the 21 st century-Methodology and results: Laxenburg, Austria, International Institute for Applied Systems Analysis, 119 p., accessed September 2010 at http://www.iiasa.ac.at/Admin/PUB/Documents/ RR-02-002.pdf.

Frayer, W.E., Monahan, T.J., Bowden, D.C., and Graybill, F.A., 1983, Status and trends of wetlands and deepwater habitats in the conterminous United States, 1950's to 1970's: Ft. Collins, Colo., Colorado State University, 31 p., accessed March 2011 at http://www.fws.gov/wetlands/ documents/gSandT/NationalReports/StatusTrendsWetlands DeepwaterHabitatsConterminousUS1950sto1970s.pdf.
Gebert, W.A., Graczyk, D.J., and Krug, W.R., 1987, Average annual runoff in the United States, 1951-80: Madison, Wis., U.S. Geological Survey geospatial dataset, accessed March 2009 at http://water.usgs.gov/GIS/metadata/usgswrd/XML/ runoff.xml.

Gesch, D.B., 2007, The National Elevation Dataset, in Maune, D.F., ed., Digital elevation model technologies and applications - The DEM users manual (2d ed.): Bethesda, Md., American Society for Photogrammetry and Remote Sensing, p. 99-118.

Gesch, D., Oimoen, M., Greenlee, S., Nelson, C., Steuck, M., and Tyler, D., 2002, The National Elevation Dataset: Photogrammetric Engineering and Remote Sensing, v. 68, no. 1, p. $5-11$.

Helms, Douglas, 1992, The development of the land capability classification, in Helms, Douglas, Readings in the history of the Soil Conservation Service: Washington, D.C., U.S. Department of Agriculture, Natural Resources Conservation Service, p. 60-73, accessed January 2010 at http://www.nrcs.usda.gov/about/history/articles/ landclassification.html.

Horn, Tammy, 2005, Bees in America-How the honey bee shaped a nation: Lexington, Ky., University Press of Kentucky, $333 \mathrm{p}$.

Hurt, D.R., 1994, American agriculture-A brief history: Ames, Iowa, Iowa State University Press, 412 p.

Kenny, J.F., Barber, N.L., Hutson, S.S., Linsey, K.S., Lovelace, J.K., and Maupin, M.A., 2009, Estimated use of water in the United States in 2005: U.S. Geological Survey Circular 1344, $52 \mathrm{p}$.

Küchler, A.W., 1964, The potential natural vegetation of the conterminous United States: New York, American Geographical Society Special Publication 36, 1 sheet.

Jaynes, D.B., and James, D., 2007, The extent of farm drainage in the United States: Paper presented at the annual meeting of the Soil And Water Conservation Society, Saddlebrook Resort, Tampa, Fla., July 21, 2007; abstract

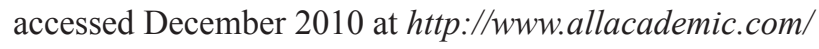
meta/p173977_index.html.

Lubowski, R.N.; Vesterby, Marlow; Bucholtz, Shawn; Baez, Alba; and Roberts, M.J., 2006, Major uses of land in the United States, 2002: U.S. Department of Agriculture, Economic Research Service, Economic Information Bulletin 14, 47 p. (Also available at $h t t p: / / w w w . e r s . u s d a . g o v /$ Publications/EIB14/.) 
Missoula Fire Sciences Laboratory, 2001, Potential natural vegetation groups, version 2000: Missoula, Mont., U.S. Department of Agriculture, Forest Service, Rocky Mountain Research Station, Missoula Fire Sciences Laboratory, geospatial data, accessed November 2009 at http://www.fs.fed.us/fire/fuelman/pnv.htm.

Oregon State University, 2008, U.S. precipitation 30-arcsec (800-m) normals (1971-2000): Corvallis, Oreg., The PRISM Climate Group, geospatial data, accessed November 2009 at http://www.prism.oregonstate.edu/.

Oregon State University [2010], Degree-day maps created daily using $50^{\circ} \mathrm{F}$ lower threshold-Normals: Corvallis, Oreg., Integrated Plant Protection Center (http://uspest.org/wea), accessed March 2010 at http://ippc2.orst.edu/US/ddmaps.html.

Ramankutty, Navin; Heller, Elizabeth; and Rhemtulla, Jeanine, 2010, Prevailing myths about agricultural abandonment and forest regrowth in the United States: Annals of the Association of American Geographers, v. 100, no. 3, p. 502-512, supplemental material, accessed February 2011

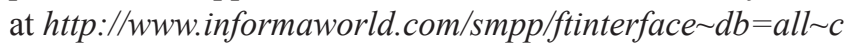
ontent $=$ a922418004 tab $=$ multimedia .

Reilly, T.E., Dennehy, K.F., Alley, W.M., and Cunningham, W.L., 2008, Ground-water availability in the United States: U.S. Geological Survey Circular 1323, 70 p. (Also available online at http://pubs.usgs.gov/circ/1323/.)

Sadras, V.O., and Calviño, P.A., 2001, Quantification of grain yield response to soil depth in soybean, maize, sunflower, and wheat: Agronomy Journal, v. 93, May-June, p. $577-583$.

Singh, Jasbir, and Dhillon, S.S., 2004, Agricultural geography (3d ed.): New Delhi, Tata McGraw-Hill, 492 p.

U.S. Department of Agriculture, 2005, 2002 Census of Agriculture, Geographic Area Series Publications, Volume 1, Chapter 2-County level data: Washington D.C., National Agricultural Statistical Service, CD-ROM. (Also available at http://www.agcensus.usda.gov/Publications/2002/ index.asp.)

U.S. Department of Agriculture, 2006, U.S. general soil map (STATSGO) data: Natural Resources Conservation Service geospatial data, accessed February 2010 at http://soildatamart.nrcs.usda.gov/USDGSM.aspx.
U.S. Department of Agriculture, 2009a, 2007 Census of Agriculture, Online Highlights, Ag Atlas Maps, Crops and Plants: Washington D.C., National Agricultural Statistical Service online data, accessed January 2011 at $h t t p: / / w w w$. agcensus.usda.gov/Publications/2007/Online_Highlights/ Ag_Atlas_Maps/Crops_and_Plants/index.asp.

U.S. Department of Agriculture, 2009b, 2007 Census of Agriculture, Online Highlights, Ag Atlas Maps, Farms: Washington D.C., National Agricultural Statistical Service online data, accessed January 2011 at $h t t p: / / w w w . a g c e n s u s . u s d a$. gov/Publications/2007/Online_Highlights/Ag_Atlas_Maps/ Farms/index.asp.

U.S. Department of Agriculture, 2009c, Briefing rooms, rice-Background: Economic Research Service, accessed

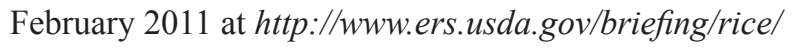
background.htm.

U.S. Department of Agriculture, 2010a, Fertilizer use and price: Economic Research Service online data, accessed January 2011 at $h t t p: / / w w w . e r s . u s d a . g o v / D a t a /$ FertilizerUse/.

U.S. Department of Agriculture, 2010b, 2009 [state] Cropland Data Layer: National Agricultural Statistics Service, geospatial data, accessed February 2010 at $h t t p: / / w w w . n a s s$. usda.gov/research/Cropland/SARSla.htm.

Waisanen, P.J., and Bliss, N.B., 2002, Changes in population and agricultural land in conterminous United States counties, 1790 to 1997: Global Biogeochemical Cycles, v. 16, no. 4, 1137, doi:10.1029/2001GB001843, 2002. (Also available at http://edcintl.cr.usgs.gov/ip/carbon_cycle/ pdfs/2001GB001843.pdf.)

Wiebold, Bill, 2000, Growing degree days and corn maturity: University of Missouri Extension, College of Agriculture, Food, and Natural Resources, Corn Facts, accessed February 2011 at $h t t p: / / p l a n t s c i . m i s s o u r i . e d u / c o r n x / c o r n f a c t s /$ corn_heat_units.pdf.

Wolock, D.M., 2003, Estimated mean annual natural ground-water recharge in the conterminous United States: U.S. Geological Survey Open-File Report 03-311, geospatial data available at http://water.usgs.gov/GIS/metadata/ usgswrd/XML/rech48grd.xml. 



\section{Appendixes 1-8}

Appendix 1—Development of Croplands in the United States ......................................................37

Appendix 2-Environmental Factors That Influence the Location of Crop Agriculture ..................38

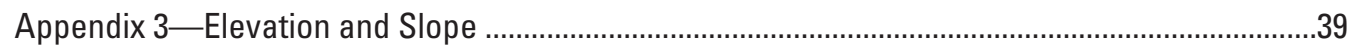

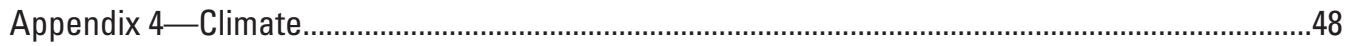

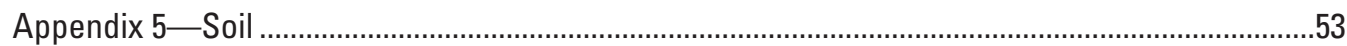

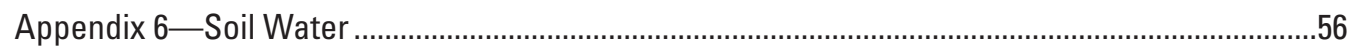

Appendix 7-Other Land Uses in Competition for Agricultural Lands ..........................................61

Appendix 8-Summary of Data Sources and Online Links to Datasets .........................................65

References Cited in the Appendixes .......................................................................................... 


\section{Appendix 1-Development of Croplands in the United States}

Data used to show development of crop agricultural lands include the geospatial dataset "Potential Natural Vegetation" and compilations of the U.S. censuses of population and agriculture. A compilation of the agricultural censuses was also used to show state-level trends in harvested cropland.

The Potential Natural Vegetation (PNV) map in figure 1 is used as a surrogate for presettlement land cover in the United States. PNV is the "climax" vegetation that will occupy a site without disturbance or climatic change and is an expression of environmental factors such as terrain, soils, and climate across an area. The original PNV map was developed by Küchler (1964). The version used in this report is an updated digital geospatial dataset developed by the Missoula Fire Sciences Laboratory (2001).

The historical expansion of agriculture is shown by extracting county census of population for years prior to the agricultural census (fig. 2) and area of improved farmland from the agricultural census for 1850-2002 (fig. 3). In the conterminous United States, a census of population has been taken every 10 years since 1790 , and information on agricultural land use has been collected since 1850 at 10 -year or 5 -year intervals. Figure 2 shows the extent of settled area for 1790 and 1830, compiled by Waisanen and Bliss (2002) from the census of population, to show the probable extent of agriculture prior to the first agricultural census. Waisanen and Bliss used spatial historical county-boundary data and matched them to the tabular census data.

County-level census of agriculture area of improved farmland for 1850-1997 compiled by Waisanen and Bliss (2002) was used to show historical extent of agriculture (fig. 3). The tabular datasets, which are no longer available online, were provided by Norman Bliss, U.S. Geological Survey (written commun., 2011). The Waisanen and Bliss compilation is available through the 1997 agricultural census. Harvested cropland (improved farmland) for the 2002 census was obtained from the 2002 Census of Agriculture (U.S. Department of Agriculture, 2005).

Trends in harvested cropland for 1879-1997 (fig. 4) generated from state-level historical cropland area were compiled by Ramankutty and others (2010) from the agricultural censuses. Ramankutty and others provide a tabular dataset. 


\section{Appendix 2-Environmental Factors That Influence the Location of Crop Agriculture}

The extent and amount of cropland in the United States are available from several sources. The most recent spatial datasets of cropland are in the Cropland Data Layer (U.S. Department of Agriculture, 2010), a raster, georeferenced, crop-specific land-cover data layer with a ground resolution of $56 \mathrm{~m}$. It is produced from satellite imagery collected during the growing season. The overall accuracy of the crop-specific portion of the data is 94 percent (U.S. Department of Agriculture, 2010). The 2009 Cropland Data Layer was used for most of the illustrations in this report. This dataset shows the spatial extent of each land cover, including individual crops, at a 56-m-cell-size resolution. Several crops were grouped together for the purposes of this report and were used to generate the map in figure 5. Vegetables and ground fruit were grouped together, tree fruits (with the exception of citrus) and nuts were grouped together, and minor crops (in terms of total land area occupied) were grouped into the "other crops" category. These groups are given in table $2-1$ and were used throughout the report. Breakdowns of the amount of land in each crop and crop group, shown in the bar graph in figure 5 , are summarized in table $2-2$. The area of land in each landcover group for the 2009 Cropland Data Layer is summarized in table 2-3.
There is no reliable way in the Cropland Data Layer to differentiate between grassland and hay or between grassland and range used for pasture or livestock. The spectral signature for grassland and hay on satellite imagery is similar and difficult to distinguish. In addition, there is no way to determine whether grassy fields or range (shrubland) are used to graze livestock or simply left fallow. To derive these estimates for the report, supplemental information from the Economic Research Service (ERS) national compilation "Major Uses of Land in the United States, 2002" (Lubowski and others, 2006) was used to differentiate the national total land area used for hay, fallow, idle and cropland pasture, grassland, and range. The total area for each matching general land cover was similar for the 2002 and 2009 datasets (table 2-4). Land-cover percentages for hay and total grassland obtained from the 2002 data were applied to the 2009 data to obtain relative land area for grassland and range (table 2-4). The distinction between pasture, rangelands, and other grazing lands is available online at $h t t p: / / w w w . e p a . g o v / o e c a a g c t / a n p r g i d x . h t m l$.

Dot density maps for the extent of cropland and total cropland area for specialty crops are available from the 2007 Census of Agriculture (U.S. Department of Agriculture, 2009a). These maps are not available as digital datasets and were used in this report simply to illustrate the primary locations for some economically significant specialty crops that occupy relatively small land areas and are not readily visible on the national scale Cropland Data Layer maps (fig. 6). Total acreage for each specialty crop is given on the online maps. These values, along with the Map Number used to generate figure 6 , are given in table 2-5. 
Table 2-1. 2009 Cropland Data Layer land-cover codes and land-cover groups used in this report (U.S. Department of Agriculture, 2010b).

[Ma, million acres; kkm², 1,000 square kilometers; NLCD, National Land Cover Database]

\begin{tabular}{|c|c|c|c|c|c|}
\hline $\begin{array}{l}\text { Cropland Data } \\
\text { Layer land- } \\
\text { cover code }\end{array}$ & Cropland Data Layer land-cover name & Land-use group & $\begin{array}{l}\text { Land area, } \\
\text { in } \mathrm{Ma}\end{array}$ & $\begin{array}{l}\text { Land area, } \\
\text { in } \mathbf{k k m}^{2}\end{array}$ & $\begin{array}{l}\text { Land area, } \\
\text { in percent of } \\
\text { total land }\end{array}$ \\
\hline \multirow[t]{2}{*}{131} & NLCD - Barren & Barren & 19.89 & 80.51 & 1.05 \\
\hline & & Barren Total & 19.89 & 80.51 & 1.05 \\
\hline 72 & Citrus & Citrus & 0.17 & 0.67 & 0.01 \\
\hline \multirow[t]{2}{*}{212} & Oranges & Citrus & 1.06 & 4.31 & 0.06 \\
\hline & & Citrus Total & 1.23 & 4.98 & 0.07 \\
\hline 1 & Corn & Corn & 80.41 & 325.44 & 4.25 \\
\hline 225 & Dbl. Crop WinWht/Corn & Corn & 0.03 & 0.14 & 0.00 \\
\hline 226 & Dbl. Crop Oats/Corn & Corn & 0.00 & 0.01 & 0.00 \\
\hline 237 & Dbl. Crop Barley/Corn & Corn & 0.02 & 0.10 & 0.00 \\
\hline \multirow[t]{2}{*}{241} & Dbl. Crop Corn/Soybeans & Corn & 0.00 & 0.01 & 0.00 \\
\hline & & Corn Total & 80.48 & 325.69 & 4.25 \\
\hline 2 & Cotton & Cotton & 9.37 & 37.93 & 0.50 \\
\hline 232 & Dbl. Crop Lettuce/Upland Cotton & Cotton & 0.01 & 0.03 & 0.00 \\
\hline \multirow[t]{2}{*}{238} & Dbl. Crop WinWht/Cotton & Cotton & 0.01 & 0.03 & 0.00 \\
\hline & & Cotton Total & 9.39 & 37.99 & 0.50 \\
\hline 63 & Woodland & Forest & 0.98 & 3.98 & 0.05 \\
\hline 141 & NLCD - Deciduous Forest & Forest & 245.55 & 993.72 & 12.98 \\
\hline 142 & NLCD - Evergreen Forest & Forest & 250.07 & 1012.04 & 13.22 \\
\hline \multirow[t]{2}{*}{143} & NLCD - Mixed Forest & Forest & 28.55 & 115.54 & 1.51 \\
\hline & & Forest Total & 525.15 & 2125.28 & 27.76 \\
\hline 36 & Alfalfa & Grassland & 10.86 & 43.96 & 0.57 \\
\hline 37 & Other Hays & Grassland & 33.78 & 136.72 & 1.79 \\
\hline 60 & Switchgrass & Grassland & 0.02 & 0.08 & 0.00 \\
\hline 61 & Fallow/Idle Cropland & Grassland & 22.22 & 89.94 & 1.17 \\
\hline 62 & Pasture/Grass & Grassland & 43.23 & 174.95 & 2.29 \\
\hline 171 & NLCD - Grassland Herbaceous & Grassland & 262.60 & 1062.74 & 13.88 \\
\hline \multirow[t]{2}{*}{181} & NLCD - Pasture/Hay & Grassland & 109.52 & 443.23 & 5.79 \\
\hline & & Grassland Total & 482.24 & 1951.63 & 25.49 \\
\hline 66 & Cherry Orchard & Orchards and grapes & 0.09 & 0.37 & 0.00 \\
\hline 67 & Peaches & Orchards and grapes & 0.05 & 0.19 & 0.00 \\
\hline 68 & Apples & Orchards and grapes & 0.16 & 0.66 & 0.01 \\
\hline 69 & Grapes & Orchards and grapes & 0.45 & 1.82 & 0.02 \\
\hline
\end{tabular}


Table 2-1. 2009 Cropland Data Layer land-cover codes and land-cover groups used in this report (U.S. Department of Agriculture, 2010b). - Continued

[Ma, million acres; kkm² , 1,000 square kilometers; NLCD, National Land Cover Database]

\begin{tabular}{|c|c|c|c|c|c|}
\hline $\begin{array}{l}\text { Cropland Data } \\
\text { Layer land- } \\
\text { cover code }\end{array}$ & Cropland Data Layer land-cover name & Land-use group & $\begin{array}{l}\text { Land area, } \\
\text { in } \mathrm{Ma}\end{array}$ & $\begin{array}{l}\text { Land area, } \\
\text { in } \mathbf{k k m}^{2}\end{array}$ & $\begin{array}{l}\text { Land area, } \\
\text { in percent of } \\
\text { total land }\end{array}$ \\
\hline 71 & Other Tree Nuts & Orchards and grapes & 0.26 & 1.04 & 0.01 \\
\hline 73 & Other Tree Fruits & Orchards and grapes & 0.02 & 0.07 & 0.00 \\
\hline 74 & Pecans & Orchards and grapes & 0.06 & 0.25 & 0.00 \\
\hline 75 & Almonds & Orchards and grapes & 0.89 & 3.60 & 0.05 \\
\hline 76 & Walnuts & Orchards and grapes & 0.32 & 1.30 & 0.02 \\
\hline 77 & Pear & Orchards and grapes & 0.01 & 0.04 & 0.00 \\
\hline 204 & Pistachios & Orchards and grapes & 0.11 & 0.46 & 0.01 \\
\hline 210 & Prunes & Orchards and grapes & 0.05 & 0.19 & 0.00 \\
\hline 211 & Olives & Orchards and grapes & 0.09 & 0.35 & 0.00 \\
\hline 217 & Pomegranates & Orchards and grapes & 0.01 & 0.05 & 0.00 \\
\hline 218 & Nectarine & Orchards and grapes & 0.00 & 0.00 & 0.00 \\
\hline 220 & Plums & Orchards and grapes & 0.01 & 0.03 & 0.00 \\
\hline \multirow[t]{2}{*}{223} & Apricots & Orchards and grapes & 0.01 & 0.05 & 0.00 \\
\hline & & Orchards and grapes Total & 2.58 & 10.46 & 0.14 \\
\hline 6 & Sunflowers & Other crops & 1.52 & 6.15 & 0.08 \\
\hline 10 & Peanuts & Other crops & 1.20 & 4.86 & 0.06 \\
\hline 11 & Tobacco & Other crops & 0.01 & 0.05 & 0.00 \\
\hline 21 & Barley & Other crops & 2.27 & 9.17 & 0.12 \\
\hline 25 & Other Small Grains & Other crops & 0.07 & 0.29 & 0.00 \\
\hline 27 & Rye & Other crops & 0.33 & 1.33 & 0.02 \\
\hline 28 & Oats & Other crops & 1.50 & 6.06 & 0.08 \\
\hline 29 & Millet & Other crops & 0.38 & 1.53 & 0.02 \\
\hline 30 & Spelt & Other crops & 0.00 & 0.01 & 0.00 \\
\hline 31 & Canola & Other crops & 0.86 & 3.48 & 0.05 \\
\hline 32 & Flaxseed & Other crops & 0.21 & 0.86 & 0.01 \\
\hline 33 & Safflower & Other crops & 0.12 & 0.47 & 0.01 \\
\hline 34 & Rape Seed & Other crops & 0.00 & 0.00 & 0.00 \\
\hline 35 & Mustard & Other crops & 0.02 & 0.09 & 0.00 \\
\hline 38 & Camelina & Other crops & 0.01 & 0.05 & 0.00 \\
\hline 41 & Sugarbeets & Other crops & 0.97 & 3.92 & 0.05 \\
\hline 44 & Other Crops & Other crops & 0.14 & 0.55 & 0.01 \\
\hline 45 & Sugarcane & Other crops & 0.84 & 3.40 & 0.04 \\
\hline
\end{tabular}


Table 2-1. 2009 Cropland Data Layer land-cover codes and land-cover groups used in this report (U.S. Department of Agriculture, 2010b). - Continued

[Ma, million acres; $\mathrm{kkm}^{2}$, 1,000 square kilometers; NLCD, National Land Cover Database]

\begin{tabular}{|c|c|c|c|c|c|}
\hline $\begin{array}{l}\text { Cropland Data } \\
\text { Layer land- } \\
\text { cover code }\end{array}$ & Cropland Data Layer land-cover name & Land-use group & $\begin{array}{l}\text { Land area, } \\
\text { in } \mathrm{Ma}\end{array}$ & $\begin{array}{l}\text { Land area, } \\
\text { in } \mathbf{k k m}^{2}\end{array}$ & $\begin{array}{l}\text { Land area, } \\
\text { in percent of } \\
\text { total land }\end{array}$ \\
\hline 56 & Hops & Other crops & 0.02 & 0.07 & 0.00 \\
\hline 57 & Herbs & Other crops & 0.06 & 0.25 & 0.00 \\
\hline 58 & Clover/Wildflowers & Other crops & 0.13 & 0.54 & 0.01 \\
\hline 59 & Seed/Sod Grass & Other crops & 0.97 & 3.91 & 0.05 \\
\hline 70 & Christmas Trees & Other crops & 0.06 & 0.25 & 0.00 \\
\hline 92 & Aquaculture & Other crops & 0.17 & 0.67 & 0.01 \\
\hline 205 & Triticale & Other crops & 0.06 & 0.22 & 0.00 \\
\hline \multirow[t]{2}{*}{224} & Vetch & Other crops & 0.00 & 0.01 & 0.00 \\
\hline & & Other crops Total & 11.91 & 48.19 & 0.63 \\
\hline \multirow[t]{2}{*}{3} & Rice & Rice & 3.35 & 13.54 & 0.18 \\
\hline & & Rice Total & 3.35 & 13.54 & 0.18 \\
\hline \multirow[t]{2}{*}{152} & NLCD - Shrubland & Shrubland & 416.72 & 1686.46 & 22.03 \\
\hline & & Shrubland Total & 416.72 & 1686.46 & 22.03 \\
\hline 4 & Sorghum & Sorghum & 6.28 & 25.41 & 0.33 \\
\hline 234 & Dbl. Crop Durum Wht/Sorghum & Sorghum & 0.01 & 0.02 & 0.00 \\
\hline 235 & Dbl. Crop Barley/Sorghum & Sorghum & 0.01 & 0.02 & 0.00 \\
\hline \multirow[t]{2}{*}{236} & Dbl. Crop WinWht/Sorghum & Sorghum & 0.03 & 0.12 & 0.00 \\
\hline & & Sorghum Total & 6.32 & 25.57 & 0.33 \\
\hline 5 & Soybeans & Soybeans & 70.57 & 285.61 & 3.73 \\
\hline 26 & W. Wht./Soy. Dbl. Crop & Soybeans & 4.24 & 17.16 & 0.22 \\
\hline 240 & Dbl. Crop Soybeans/Oats & Soybeans & 0.01 & 0.03 & 0.00 \\
\hline \multirow[t]{2}{*}{254} & Dbl. Crop Barley/Soybeans & Soybeans & 0.07 & 0.29 & 0.00 \\
\hline & & Soybeans Total & 74.89 & 303.09 & 3.96 \\
\hline 121 & NLCD - Developed/Open Space & Urban & 72.27 & 292.48 & 3.82 \\
\hline 122 & NLCD - Developed/Low Intensity & Urban & 27.73 & 112.22 & 1.47 \\
\hline 123 & NLCD - Developed/Medium Intensity & Urban & 10.02 & 40.55 & 0.53 \\
\hline \multirow[t]{2}{*}{124} & NLCD - Developed/High Intensity & Urban & 3.31 & 13.38 & 0.17 \\
\hline & & Urban Total & 113.33 & 458.63 & 5.99 \\
\hline 12 & Sweet Corn & Vegetables and ground fruit & 0.28 & 1.13 & 0.01 \\
\hline 13 & Pop. or Orn. Corn & Vegetables and ground fruit & 0.11 & 0.44 & 0.01 \\
\hline 14 & Mint & Vegetables and ground fruit & 0.02 & 0.07 & 0.00 \\
\hline 42 & Dry Beans & Vegetables and ground fruit & 1.28 & 5.20 & 0.07 \\
\hline
\end{tabular}


Table 2-1. 2009 Cropland Data Layer land-cover codes and land-cover groups used in this report (U.S. Department of Agriculture, 2010b). - Continued

[Ma, million acres; kkm² , 1,000 square kilometers; NLCD, National Land Cover Database]

\begin{tabular}{|c|c|c|c|c|c|}
\hline $\begin{array}{l}\text { Cropland Data } \\
\text { Layer land- } \\
\text { cover code }\end{array}$ & Cropland Data Layer land-cover name & Land-use group & $\begin{array}{c}\text { Land area, } \\
\text { in } \mathrm{Ma}\end{array}$ & $\begin{array}{l}\text { Land area, } \\
\text { in } \mathbf{k k m}^{2}\end{array}$ & $\begin{array}{l}\text { Land area, } \\
\text { in percent of } \\
\text { total land }\end{array}$ \\
\hline 43 & Potatoes & Vegetables and ground fruit & 0.99 & 4.00 & 0.05 \\
\hline 46 & Sweet Potatoes & Vegetables and ground fruit & 0.03 & 0.12 & 0.00 \\
\hline 47 & Misc. Vegs. \& Fruits & Vegetables and ground fruit & 0.17 & 0.70 & 0.01 \\
\hline 48 & Watermelon & Vegetables and ground fruit & 0.03 & 0.10 & 0.00 \\
\hline 49 & Onions & Vegetables and ground fruit & 0.08 & 0.32 & 0.00 \\
\hline 52 & Lentils & Vegetables and ground fruit & 0.36 & 1.46 & 0.02 \\
\hline 53 & Peas & Vegetables and ground fruit & 0.91 & 3.70 & 0.05 \\
\hline 54 & Tomatoes & Vegetables and ground fruit & 0.15 & 0.60 & 0.01 \\
\hline 55 & Caneberry & Vegetables and ground fruit & 0.01 & 0.04 & 0.00 \\
\hline 206 & Carrots & Vegetables and ground fruit & 0.00 & 0.01 & 0.00 \\
\hline 207 & Asparagus & Vegetables and ground fruit & 0.00 & 0.01 & 0.00 \\
\hline 208 & Garlic & Vegetables and ground fruit & 0.01 & 0.04 & 0.00 \\
\hline 209 & Cantaloupe & Vegetables and ground fruit & 0.02 & 0.07 & 0.00 \\
\hline 214 & Broccoli & Vegetables and ground fruit & 0.01 & 0.04 & 0.00 \\
\hline 216 & Peppers & Vegetables and ground fruit & 0.01 & 0.05 & 0.00 \\
\hline 219 & Greens & Vegetables and ground fruit & 0.01 & 0.02 & 0.00 \\
\hline 221 & Strawberries & Vegetables and ground fruit & 0.02 & 0.09 & 0.00 \\
\hline 222 & Squash & Vegetables and ground fruit & 0.01 & 0.06 & 0.00 \\
\hline 227 & Lettuce & Vegetables and ground fruit & 0.04 & 0.15 & 0.00 \\
\hline 229 & Cucumber & Vegetables and ground fruit & 0.00 & 0.01 & 0.00 \\
\hline 230 & Pumpkin & Vegetables and ground fruit & 0.04 & 0.18 & 0.00 \\
\hline 231 & Dbl. Crop Lettuce/Cantaloupe & Vegetables and ground fruit & 0.00 & 0.01 & 0.00 \\
\hline 242 & Blueberry & Vegetables and ground fruit & 0.10 & 0.41 & 0.01 \\
\hline 243 & Cabbage & Vegetables and ground fruit & 0.01 & 0.05 & 0.00 \\
\hline 244 & Cauliflower & Vegetables and ground fruit & 0.00 & 0.01 & 0.00 \\
\hline 245 & Celery & Vegetables and ground fruit & 0.00 & 0.01 & 0.00 \\
\hline 246 & Radish & Vegetables and ground fruit & 0.00 & 0.01 & 0.00 \\
\hline 247 & Turnip & Vegetables and ground fruit & 0.00 & 0.00 & 0.00 \\
\hline \multirow[t]{2}{*}{250} & Cranberry & Vegetables and ground fruit & 0.01 & 0.03 & 0.00 \\
\hline & & Vegetables and ground fruit Total & 4.73 & 19.16 & 0.25 \\
\hline 87 & Wetlands & Wetlands & 0.09 & 0.35 & 0.00 \\
\hline 190 & NLCD - Woody Wetlands & Wetlands & 67.32 & 272.45 & 3.56 \\
\hline
\end{tabular}


44 Environmental Factors That Influence the Location of Crop Agriculture in the Conterminous United States

Table 2-1. 2009 Cropland Data Layer land-cover codes and land-cover groups used in this report (U.S. Department of Agriculture, 2010b). - Continued

[Ma, million acres; $\mathrm{kkm}^{2}, 1,000$ square kilometers; NLCD, National Land Cover Database]

\begin{tabular}{|c|c|c|c|c|c|}
\hline $\begin{array}{l}\text { Cropland Data } \\
\text { Layer land- } \\
\text { cover code }\end{array}$ & Cropland Data Layer land-cover name & Land-use group & $\begin{array}{l}\text { Land area, } \\
\text { in } \mathrm{Ma}\end{array}$ & $\begin{array}{l}\text { Land area, } \\
\text { in } \mathbf{k k m}^{2}\end{array}$ & $\begin{array}{l}\text { Land area, } \\
\text { in percent of } \\
\text { total land }\end{array}$ \\
\hline \multirow[t]{2}{*}{195} & NLCD - Herbaceous Wetlands & Wetlands & 19.75 & 79.92 & 1.04 \\
\hline & & Wetlands Total & 87.16 & 352.72 & 4.61 \\
\hline 22 & Durum Wheat & Wheat & 2.23 & 9.01 & 0.12 \\
\hline 23 & Spring Wheat & Wheat & 13.85 & 56.05 & 0.73 \\
\hline \multirow[t]{3}{*}{24} & Winter Wheat & Wheat & 36.19 & 146.45 & 1.91 \\
\hline & & Wheat Total & 52.26 & 211.51 & 2.76 \\
\hline & & Total Land Cover & 1891.63 & 7655.41 & 100.00 \\
\hline \multirow[t]{2}{*}{111} & NLCD - Open Water & Water & 32.69 & 132.31 & 1.70 \\
\hline & & Water Total & 32.69 & 132.31 & 1.70 \\
\hline \multirow[t]{2}{*}{112} & NLCD - Perennial Ice/Snow & Perennial Ice/Snow & 0.32 & 1.31 & 0.02 \\
\hline & & Perennial Ice/Snow Total & 0.32 & 1.31 & 0.02 \\
\hline
\end{tabular}


Table 2-2. Land area in each crop or crop group in the 2009 Cropland Data Layer for the conterminous United States (U.S. Department of Agriculture, 2010b).

[Ma, million acres; $\mathrm{kkm}^{2}$, thousand square kilometers]

\begin{tabular}{lccc}
\hline \multicolumn{1}{c}{ Crop or crop group } & $\begin{array}{c}\text { Land area, } \\
\text { in Ma }\end{array}$ & $\begin{array}{c}\text { Land area, } \\
\text { in kkm² }\end{array}$ & $\begin{array}{c}\text { Land area, } \\
\text { in percent of } \\
\text { total combined cropland }\end{array}$ \\
\hline Corn & 80.48 & 325.69 & 32.56 \\
Soybeans & 74.89 & 303.09 & 30.30 \\
Wheat & 52.26 & 211.51 & 21.15 \\
Other crops & 11.91 & 48.19 & 4.82 \\
Cotton & 9.39 & 37.99 & 3.80 \\
Sorghum & 6.32 & 25.57 & 2.56 \\
Vegetables and ground fruit & 4.73 & 19.16 & 1.92 \\
Rice & 3.35 & 13.54 & 1.35 \\
Orchards and grapes & 2.58 & 10.46 & 1.04 \\
Citrus & 1.23 & 4.98 & 0.50 \\
All crops combined & $\mathbf{2 4 7 . 1 4}$ & $\mathbf{1 , 0 0 0 . 1 8}$ & $\mathbf{1 0 0 . 0 0}$ \\
Grassland and pasture; includes hay & 482.24 & $1,951.63$ & \\
\hline
\end{tabular}

Table 2-3. Area of land in each land cover group for the 2009 Cropland Data Layer for the conterminous United States (U.S. Department of Agriculture, 2010b).

[Ma, million acres; $\mathrm{kkm}^{2}$, thousand square kilometers]

\begin{tabular}{lccc}
\hline \multicolumn{1}{c}{ Land-cover category } & $\begin{array}{c}\text { 2009 Cropland Data Layer, } \\
\text { in Ma }\end{array}$ & $\begin{array}{c}\text { 2009 Cropland Data Layer, } \\
\text { in } \mathbf{~ k m}^{2}\end{array}$ & Percent land cover \\
\hline Cropland & 247 & 1,000 & 13 \\
Grassland and pasture; includes hay & 482 & 1,952 & 25 \\
Forest & 525 & 2,125 & 28 \\
Urban & 113 & 459 & 6 \\
Shrublands, wetlands, and barren & 525 & 2,120 & 28 \\
Total & 1,892 & 7,656 & 100 \\
\hline
\end{tabular}


Table 2-4. Comparison of land area in each land-cover group reported in "Major Uses of Land, 2002" (Lubowski and others, 2006) and the 2009 Cropland Data Layer (U.S. Department of Agriculture, 2010b), and estimated land area for land-cover groups not differentiated in the 2009 Cropland Data Layer for the conterminous United States.

[Ma, million acres; $\mathrm{kkm}^{2}$, thousand square kilometers]

\begin{tabular}{|c|c|c|c|c|c|c|}
\hline Land-cover category & $\begin{array}{l}\text { “Major Uses of } \\
\text { Land, 2002," } \\
\text { in Ma }\end{array}$ & $\begin{array}{l}\text { “Major Uses of } \\
\text { Land, 2002," } \\
\text { in } \mathbf{k k m}^{2}\end{array}$ & $\begin{array}{l}\text { Percent land } \\
\text { cover for } \\
\text { "Major Uses } \\
\text { of Land, 2002” }\end{array}$ & $\begin{array}{l}2009 \text { Cropland } \\
\text { Data Layer, } \\
\text { in Ma }\end{array}$ & $\begin{array}{l}2009 \text { Cropland } \\
\text { Data Layer, } \\
\text { in kkm² }\end{array}$ & $\begin{array}{c}\text { Percent land } \\
\text { cover for the } \\
\text { Cropland Data } \\
\text { Layer }\end{array}$ \\
\hline Harvested cropland without hay & 242 & 979 & 13 & 247 & 1,000 & 13 \\
\hline Hay & 65 & 263 & 3 & $66^{1}$ & 267 & 3 \\
\hline Crop failure and cultivated summer fallow & 33 & 133 & 2 & $128^{2}$ & 518 & 7 \\
\hline Idle cropland & 40 & 162 & 2 & & & \\
\hline Cropland pasture & 62 & 251 & 3 & & & \\
\hline Total cropland & 441 & 1,788 & 23 & $441^{3}$ & 1,785 & 23 \\
\hline Grassland and other pasture & & & & $288^{4}$ & 1,165 & 15 \\
\hline Range & & Not differentiated & & 16 & & \\
\hline Total grassland pasture and range & 584 & 2,363 & 31 & $\mathbf{5 8 3}^{6}$ & 2,359 & 31 \\
\hline Total forest & 559 & 2,262 & 30 & 525 & 2,125 & 28 \\
\hline Total urban & 59 & 239 & 3 & 113 & 459 & 6 \\
\hline Total miscellaneous and special uses & 250 & 1,012 & 13 & $229^{7}$ & 927 & 12 \\
\hline Total land cover & 1,893 & 7,664 & 100 & 1,892 & 7,655 & 100 \\
\hline
\end{tabular}

\footnotetext{
${ }^{1}$ Hay based on 21 percent of harvested cropland per "Major Uses of Land, 2002."

${ }^{2}$ Crop failure and cultivated summer fallow equal the difference between total cropland (based on 23 percent total land use per "Major Uses of Land, 2002") and the sum of hay plus harvested cropland. The $128 \mathrm{Ma}$ value was subtracted from the $482 \mathrm{Ma}$ value for grassland and pasture in the Cropland Data Layer.

${ }^{3}$ Total cropland based on 23 percent total land use per "Major Uses of Land, 2002."

${ }^{4}$ Grassland and other pasture based on 482 Ma from 2009 Cropland Data Layer, minus the sum of Hay (66 Ma) plus other cropland (128 Ma).

${ }^{5}$ Range is the difference between the Total grassland pasture and range (583 Ma) and Grassland and other pasture (288 Ma).

${ }^{6}$ Total grassland pasture and range based on 31 percent of Total land cover per "Major Uses of Land, 2002."

${ }^{7}$ Total miscellaneous based on difference between Total land cover (1,892 Ma) and the sum of all other categories (1,662 Ma).
} 
Table 2-5. Total acreage grown for selected grain and specialty crops for the conterminous United States (U.S. Department of Agriculture, 2009a).

[km², square kilometers; USDA, U.S. Department of Agriculture]

\begin{tabular}{lrcc}
\hline \multicolumn{1}{c}{ Crop } & Area, in acres & Area, in km² & USDA Map Number \\
\hline Barley & $3,521,957$ & 14,253 & $07-\mathrm{M} 176$ \\
Oats & $1,509,149$ & 6,107 & $07-\mathrm{M} 178$ \\
Rye & 267,361 & 1,082 & $07-\mathrm{M} 180$ \\
Sunflowers for oil & $1,710,057$ & 6,920 & $07-\mathrm{M} 182$ \\
Canola & $1,149,682$ & 4,653 & $07-\mathrm{M} 184$ \\
Sunflowers for seed & 290,096 & 1,174 & $07-\mathrm{M} 183$ \\
Dry edible beans & $1,455,549$ & 5,890 & $07-\mathrm{M} 197$ \\
Dry edible peas & 848,874 & 3,435 & $07-\mathrm{M} 198$ \\
Peanuts & $12,000,564$ & 48,565 & $07-\mathrm{M} 203$ \\
Potatoes & $1,131,963$ & 4,581 & $07-\mathrm{M} 199$ \\
Tobacco & 359,846 & 1,456 & $07-\mathrm{M} 191$ \\
Sugarbeets & $1,253,817$ & 5,074 & $07-\mathrm{M} 201$ \\
Sugarcane & 846,666 & 3,426 & $07-\mathrm{M} 202$ \\
Strawberries & 60,353 & 244 & $07-\mathrm{M} 232$ \\
Blueberries & 55,601 & 225 & $07-\mathrm{M} 231$ \\
\hline
\end{tabular}




\section{Appendix 3-Elevation and Slope}

The National Elevation Dataset (NED) can be used to identify those areas that are constrained for agricultural production by elevation and slope. The NED is composed of raster elevation data at a resolution of 1 arc-second (approximately $30 \mathrm{~m}$ ) for the conterminous United States (Gesch, 2007; Gesch and others, 2002). The NED 30-m data are available in 1,390 separate raster data files and are too large, when combined, to be useful for national-scale analyses. To make the 30-m NED usable for national analyses, 30-m elevation raster data were bilinearly resampled to $100 \mathrm{~m}$ (NED $100 \mathrm{~m}$ ) and assembled to 1-degree grids (Falcone, 2003). To determine the amount of cropland at higher elevations, the NED $100 \mathrm{~m}$ was converted to $56 \mathrm{~m}$ and combined with the 2009 Cropland Data Layer to calculate the percentage of land area in each crop group for elevations higher than 2,000 m (table 3-1).

Percent slope was generated from the NED 100-m raster dataset by calculating a slope surface using the ARCInfo Spatial Analyst $>$ Surface Analysis $>$ Slope tool. To determine the amount of cropland on each slope category (fig. 7) the NED $100 \mathrm{~m}$ was converted to $56 \mathrm{~m}$ and was combined with the 2009 Cropland Data Layer to calculate the percentage of land area in each crop group for each slope category $(1,2,3$, and greater than 4 percent) (table 3-2). The combined raster dataset was used to generate a map showing the location of crops on land with 3 percent or greater slope (fig. 8).

Table 3-1. Land area in each crop or crop group above 2,000 meters elevation in the 2009 Cropland Data Layer for the conterminous United States (Falcone, 2003; U.S. Department of Agriculture, 2010b).

[m, meters; Ma, million acres; $\mathrm{kkm}^{2}$, thousand square kilometers]

\begin{tabular}{lccc}
\hline \multicolumn{1}{c}{ Crop or crop group } & $\begin{array}{c}\text { Land area, } \\
\text { in } \mathbf{~ M a}\end{array}$ & $\begin{array}{c}\text { Land area, } \\
\text { in } \mathbf{k k m}^{2}\end{array}$ & $\begin{array}{c}\text { Land area, in percent } \\
\text { of total combined } \\
\text { cropland above } \\
\mathbf{2 , 0 0 0 ~} \mathbf{~ m}\end{array}$ \\
\hline Corn & 0.0 & 0.01 & 0.07 \\
Soybeans & 0.0 & 0.0 & 0.0 \\
Wheat & 0.83 & 3.37 & 29.31 \\
Other crops & 1.12 & 4.55 & 39.53 \\
Cotton & 0.0 & 0.0 & 0.04 \\
Sorghum & 0.0 & 0.01 & 0.1 \\
Vegetables and ground fruit & 0.88 & 0.36 & 30.92 \\
Rice & 0.0 & 0.0 & 0.0 \\
Orchards and grapes & 0.0 & 0.0 & 0.0 \\
Citrus & 0.0 & 0.0 & 0.0 \\
All crops above $\mathbf{2 , 0 0 0 ~} \mathbf{m}$ & $\mathbf{2 . 8 4}$ & 11.51 & 100.00 \\
All crops & $\mathbf{2 4 7 . 1 4}$ & $\mathbf{1 , 0 0 0 . 1 8}$ & $\mathbf{1 . 1 5}$ \\
\hline
\end{tabular}


Table 3-2. Land area in each crop or crop group for each slope range in the 2009 Cropland Data Layer for the conterminous United States (Falcone, 2003; U.S. Department of Agriculture, 2010b).

[Ma, million acres; $\mathrm{kkm}^{2}$, thousand square kilometers]

\begin{tabular}{|c|c|c|c|c|c|c|c|c|c|c|c|c|c|c|c|}
\hline \multirow{2}{*}{$\begin{array}{c}\text { Slope range, in percent } \\
\text { Crop or crop group }\end{array}$} & \multicolumn{3}{|c|}{0 to 1} & \multicolumn{3}{|c|}{$>1$ to 2} & \multicolumn{3}{|c|}{$>2$ to 3} & \multicolumn{3}{|c|}{$>3$ to 4} & \multicolumn{3}{|c|}{$>4$} \\
\hline & $\begin{array}{c}\text { Land area, } \\
\text { in } \mathrm{Ma}\end{array}$ & $\begin{array}{l}\text { Land area, } \\
\text { in } \mathbf{k k m}^{2}\end{array}$ & $\begin{array}{c}\text { Land area, } \\
\text { in percent } \\
\text { of total } \\
\text { for crop }\end{array}$ & $\begin{array}{l}\text { Land area, } \\
\text { in } \mathrm{Ma}\end{array}$ & $\begin{array}{c}\text { Land area, } \\
\text { in } \mathbf{k k m}^{2}\end{array}$ & $\begin{array}{l}\text { Land area, } \\
\text { in percent } \\
\text { of total f } \\
\text { or crop }\end{array}$ & $\begin{array}{l}\text { Land area, } \\
\text { in } \mathrm{Ma}\end{array}$ & $\begin{array}{l}\text { Land area, } \\
\text { in } \mathbf{k k m}^{2}\end{array}$ & $\begin{array}{c}\text { Land area, } \\
\text { in percent } \\
\text { of total } \\
\text { for crop }\end{array}$ & $\begin{array}{l}\text { Land area, } \\
\text { in } \mathrm{Ma}\end{array}$ & $\begin{array}{c}\text { Land area, } \\
\text { in } \mathbf{k k m}^{2}\end{array}$ & $\begin{array}{c}\text { Land area, } \\
\text { in percent } \\
\text { of total } \\
\text { for crop }\end{array}$ & $\begin{array}{l}\text { Land area, } \\
\text { in } \mathrm{Ma}\end{array}$ & $\begin{array}{c}\text { Land area, } \\
\text { in } \mathbf{k k m}^{2}\end{array}$ & $\begin{array}{c}\text { Land area, } \\
\text { in percent } \\
\text { of total } \\
\text { for crop }\end{array}$ \\
\hline Corn & 19.08 & 77.23 & 23.71 & 32.13 & 130.02 & 39.92 & 12.69 & 51.36 & 15.77 & 6.78 & 27.43 & 8.42 & 9.80 & 39.65 & 12.17 \\
\hline Soybeans & 22.02 & 89.11 & 29.40 & 29.52 & 119.47 & 39.42 & 10.94 & 44.29 & 14.61 & 5.52 & 22.36 & 7.38 & 6.88 & 27.85 & 9.19 \\
\hline Wheat & 10.24 & 41.44 & 19.59 & 22.14 & 89.59 & 42.36 & 8.95 & 36.21 & 17.12 & 4.50 & 18.22 & 8.61 & 6.44 & 26.05 & 12.32 \\
\hline Other crops & 3.44 & 13.92 & 28.89 & 4.50 & 18.19 & 37.75 & 1.75 & 7.07 & 14.68 & 0.91 & 3.66 & 7.60 & 1.32 & 5.34 & 11.08 \\
\hline Cotton & 3.68 & 14.89 & 39.19 & 4.43 & 17.94 & 47.23 & 0.82 & 3.33 & 8.76 & 0.29 & 1.16 & 3.06 & 0.17 & 0.67 & 1.76 \\
\hline Sorghum & 1.80 & 7.30 & 28.56 & 2.79 & 11.28 & 44.11 & 0.97 & 3.92 & 15.32 & 0.44 & 1.78 & 6.97 & 0.32 & 1.29 & 5.04 \\
\hline Vegetables and ground fruit & 1.24 & 5.02 & 26.18 & 1.77 & 7.18 & 37.49 & 0.70 & 2.83 & 14.76 & 0.36 & 1.44 & 7.53 & 0.66 & 2.69 & 14.04 \\
\hline Rice & 2.51 & 10.13 & 74.80 & 0.80 & 3.25 & 24.03 & 0.03 & 0.11 & 0.84 & 0.01 & 0.02 & 0.17 & 0.01 & 0.02 & 0.16 \\
\hline Orchards and grapes & 1.13 & 4.60 & 43.99 & 0.88 & 3.55 & 33.94 & 0.21 & 0.84 & 8.08 & 0.12 & 0.47 & 4.49 & 0.25 & 0.99 & 9.51 \\
\hline Citrus & 0.76 & 3.08 & 61.77 & 0.32 & 1.28 & 25.79 & 0.07 & 0.30 & 5.95 & 0.03 & 0.13 & 2.64 & 0.05 & 0.19 & 3.85 \\
\hline All crops & 65.91 & 266.73 & 26.67 & 99.29 & 401.81 & 40.17 & 37.13 & 150.25 & 15.02 & 18.95 & 76.67 & 7.67 & 25.87 & 104.71 & 10.47 \\
\hline
\end{tabular}




\section{Appendix 4-Climate}

Cumulative growing degree-days and precipitation were used to identify favorable climates for the production of selected crops and crop groups. The 30-year average for 1971-2000 (normal) cumulative growing degree-day geospatial dataset (0.010281-degree cell size) was provided by Leonard Coop, Integrated Plant Protection Center, Oregon State University (written commun., 2009). Degree-day maps generated by Coop take into account elevation, terrain, and local effects to show degree-day accumulations over a given time period (Oregon State University, 2010). "Normal" refers to the 30-year annual average of climatological data (temperature, precipitation, growing degree-days). At the time of data compilation and writing for this report, the 1981-2010 normals were not available.

The original dataset was provided in geographic coordinates that were reprojected into Albers Equal Area, resulting in a raster dataset with an approximately $1,013 \mathrm{~m}$ cell size. The raster dataset was then resampled (Nearest method) to $56 \mathrm{~m}$ cell size so that it could be combined with the Cropland Data Layer. To determine the amount of cropland for each range of degree-days (fig. 9) the 56-m degree-day raster dataset was combined with the 2009 Cropland Data Layer to calculate the percentage of land area in each crop group for each degree-day range (table 4-1).

Average annual 1971-2000 (normal) precipitation spatial data were obtained from the Parameter-elevation Regressions on Independent Slopes Model (PRISM) climate mapping system, Oregon State University (2008). Distribution of precipitation point measurements to a spatial raster dataset was accomplished by using the PRISM model, developed and applied by Chris Daly of the PRISM Climate Group at Oregon State University (2008). The precipitation raster dataset was then resampled (Nearest method) to $56 \mathrm{~m}$ cell size so that it could be combined with the 2009 Cropland Data Layer. To determine the amount of cropland for each precipitation range (fig. 10) the 56-m precipitation raster dataset was combined with the 2009 Cropland Data Layer to calculate the percentage of land area in each crop group for each precipitation range (table 4-2).

Generation of favorable water and heat (growing degreeday) boundaries for selected crops was done by combining the degree-day and precipitation raster datasets for selected crops. The most comprehensive list of growing degree-day thresholds was optioned from Fischer and others, 2002 (appendix IV). Water-requirement thresholds are available from Brouwer and Heibloem (1986). Thresholds used for the crops shown in figure 11 were obtained from these sources and are listed in table 4-3. For each crop, a separate raster dataset was extracted from the degree-day and precipitation raster dataset for the sub-optimal and optimal heat and water thresholds, resulting in four separate raster datasets for each crop. Using corn as an example, the sub-optimal heat requirement is 1,900 degree-days, so a raster dataset was generated by selecting all values greater than 1,900. The sub-optimal degree-day and precipitation raster dataset for each crop was combined to result in a raster dataset showing the extent of sub-optimal conditions for that crop. The same process was used to generate the optimal raster dataset for each crop. The optimal and sub-optimal raster datasets were overlain to show the extent of favorable climate for selected crops, and the extent of each crop was subsequently overlain on the raster dataset maps. These maps are intended to be used as a general indication of the extent of favorable climate for specific crops. Many cultivars for each crop have been developed to extend the range in which they can be grown. In addition, irrigation can be used to extend the range into areas that do not receive enough precipitation to support the crop.

The extent of irrigated cropland from surface-water and groundwater sources was determined from "Estimated Use of Water in the United States, 2005" (Kenney and others, 2009). Irrigation water use includes water that is applied by an irrigation system to sustain plant growth in all agricultural and horticultural practices (Kenney and others, 2009). This source provides withdrawals of water for irrigation in million gallons per day. Also provided is total amount of irrigated land in acres. The extent of irrigated cropland from surface-water and groundwater sources (fig. 12) was generated by converting county-level withdrawal estimates for 2005 to withdrawals in thousand acre-feet per year and joining the converted withdrawals to a geospatial raster dataset generated by combining county boundaries and the 2009 Cropland Data Layer so that areas of irrigated cropland could be mapped. This method spreads the irrigation use across all the cropland in the county. In reality, only selected fields within each county are irrigated. More detailed information about the location of irrigated fields was not available at the time this report was written.

To supplement the extent of irrigated cropland, dot density maps are used to show the extent of irrigated cropland for selected crops (fig. 13). These maps are available from the 2007 Census of Agriculture (U.S. Department of Agriculture, 2009a). These maps are not available in this report as digital datasets and were used simply to illustrate the primary locations for irrigated cropland. Total irrigated acreage for each crop shown in figure 13 is given on the online maps. These values, along with the Map Number used to generate the figure, are given in table 4-4.

Areas of groundwater decline in the United States were obtained from Reilly and others (2008). The areas delineated on the upper map in figure 14 were generated from a combination of wells in the U.S. Geological Survey National Water Information System (NWIS) database where measured groundwater-level difference over time is greater than $12 \mathrm{~m}$, and areas in excess of $1,000 \mathrm{~km}^{2}$ that have groundwater-level decline in excess of $12 \mathrm{~m}$ in at least one confined aquifer since predevelopment or in excess of $7.5 \mathrm{~m}$ of decline in unconfined aquifers since predevelopment. The dataset of NWIS wells and the polygon areas shown in the map were provided by William Cunningham, U.S. Geological Survey (written commun., 2011) Well locations were converted to a $10-\mathrm{km}^{2}$ raster dataset so that cells that had one or more wells in decline 
Table 4-1. Land area in each crop or crop group for each growing degree-day range in the 2009 Cropland Data Layer for the conterminous United States (Oregon State University, 2010; U.S. Department of Agriculture, 2010b).

[Ma, million acres; $\mathrm{kkm}^{2}$, thousand square kilometers]

\begin{tabular}{|c|c|c|c|c|c|c|c|c|c|c|c|c|c|c|c|}
\hline Category & & 0 to 2,000 & & & 2,000 to 3,00 & & & 3,000 to 4,00 & & & 4,000 to 5,00 & & & $>5,000$ & \\
\hline Crop or crop group & $\begin{array}{l}\text { Land area, } \\
\text { in } \mathrm{Ma}\end{array}$ & $\begin{array}{c}\text { Land area, } \\
\text { in } \mathbf{k k m}^{2}\end{array}$ & $\begin{array}{c}\text { Land area, } \\
\text { in percent } \\
\text { of total } \\
\text { for crop }\end{array}$ & $\begin{array}{l}\text { Land area, } \\
\text { in } \mathrm{Ma}\end{array}$ & $\begin{array}{c}\text { Land area, } \\
\text { in } \mathbf{k k m}^{2}\end{array}$ & $\begin{array}{c}\text { Land area, } \\
\text { in percent } \\
\text { of total } \\
\text { for crop }\end{array}$ & $\begin{array}{c}\text { Land area, } \\
\text { in } \mathrm{Ma}\end{array}$ & $\begin{array}{c}\text { Land area, } \\
\text { in } \mathbf{k k m}^{2}\end{array}$ & $\begin{array}{c}\text { Land area, } \\
\text { in percent } \\
\text { of total } \\
\text { for crop }\end{array}$ & $\begin{array}{l}\text { Land area, } \\
\text { in } \mathrm{Ma}\end{array}$ & $\begin{array}{c}\text { Land area, } \\
\text { in } \mathbf{k k m}^{2}\end{array}$ & $\begin{array}{c}\text { Land area, } \\
\text { in percent } \\
\text { of total } \\
\text { for crop }\end{array}$ & $\begin{array}{l}\text { Land area, } \\
\text { in } \mathrm{Ma}\end{array}$ & $\begin{array}{c}\text { Land area, } \\
\text { in } \mathbf{k k m}^{2}\end{array}$ & $\begin{array}{c}\text { Land area, } \\
\text { in percent } \\
\text { of total } \\
\text { for crop }\end{array}$ \\
\hline Corn & 0.79 & 3.19 & 0.98 & 35.89 & 145.23 & 44.59 & 32.94 & 133.31 & 40.93 & 6.13 & 24.82 & 7.62 & 4.73 & 19.15 & 5.88 \\
\hline Soybeans & 1.01 & 4.07 & 1.34 & 28.85 & 116.74 & 38.52 & 26.14 & 105.80 & 34.91 & 11.67 & 47.25 & 15.59 & 7.22 & 29.23 & 9.64 \\
\hline Wheat & 6.63 & 26.82 & 12.68 & 19.87 & 80.44 & 38.03 & 9.14 & 36.97 & 17.48 & 10.04 & 40.64 & 19.21 & 6.58 & 26.64 & 12.59 \\
\hline Other crops & 2.54 & 10.28 & 21.34 & 5.10 & 20.62 & 42.79 & 0.53 & 2.13 & 4.41 & 0.82 & 3.31 & 6.87 & 2.93 & 11.85 & 24.59 \\
\hline Cotton & 0.00 & 0.00 & 0.00 & 0.00 & 0.00 & 0.00 & 0.01 & 0.04 & 0.11 & 3.83 & 15.48 & 40.75 & 5.55 & 22.47 & 59.14 \\
\hline Sorghum & 0.00 & 0.02 & 0.08 & 0.15 & 0.59 & 2.32 & 2.06 & 8.34 & 32.63 & 1.71 & 6.94 & 27.13 & 2.39 & 9.68 & 37.84 \\
\hline Vegetables and ground fruit & 1.07 & 4.32 & 22.53 & 2.73 & 11.07 & 57.78 & 0.50 & 2.02 & 10.53 & 0.15 & 0.62 & 3.23 & 0.28 & 1.14 & 5.93 \\
\hline Rice & 0.00 & 0.00 & 0.00 & 0.00 & 0.00 & 0.00 & 0.00 & 0.00 & 0.01 & 1.57 & 6.34 & 46.84 & 1.78 & 7.20 & 53.15 \\
\hline Orchards and grapes & 0.03 & 0.12 & 1.12 & 0.24 & 0.98 & 9.35 & 0.14 & 0.55 & 5.27 & 0.89 & 3.60 & 34.40 & 1.29 & 5.22 & 49.87 \\
\hline Citrus & 0.00 & 0.00 & 0.00 & 0.00 & 0.00 & 0.00 & 0.00 & 0.01 & 0.12 & 0.00 & 0.01 & 0.12 & 1.23 & 4.97 & 99.76 \\
\hline All crops & 12.04 & 48.75 & 4.87 & 92.79 & 375.56 & 37.55 & 71.45 & 289.20 & 28.91 & 36.83 & 149.07 & 14.90 & 34.00 & 137.61 & 13.76 \\
\hline
\end{tabular}


Table 4-2. Land area in each crop or crop group for precipitation category in the 2009 Cropland Data Layer for the conterminous United States (Falcone, 2003; U.S. Department of Agriculture, 2010b).

[mm/yr, millimeters per year; Ma, million acres; $\mathrm{kkm}^{2}$, thousand square kilometers]

\begin{tabular}{|c|c|c|c|c|c|c|c|c|c|c|c|c|c|c|c|}
\hline \multirow{2}{*}{$\begin{array}{l}\text { Precipitation category, } \\
\text { in } \mathrm{mm} / \mathrm{yr}\end{array}$} & \multicolumn{3}{|c|}{0 to 538} & \multicolumn{3}{|c|}{$>538$ to 913} & \multicolumn{3}{|c|}{$>913$ to 1,271} & \multicolumn{3}{|c|}{$>1,271$ to 2,032} & \multicolumn{3}{|c|}{$>2,032$} \\
\hline & $\begin{array}{l}\text { Land area, } \\
\text { in } \mathrm{Ma}\end{array}$ & $\begin{array}{l}\text { Land area, } \\
\text { in } \mathbf{k k m}^{2}\end{array}$ & $\begin{array}{c}\text { Land area, } \\
\text { in percent } \\
\text { of total } \\
\text { for crop }\end{array}$ & $\begin{array}{l}\text { Land area, } \\
\text { in } \mathrm{Ma}\end{array}$ & $\begin{array}{c}\text { Land area, } \\
\text { in } \mathbf{k k m}^{2}\end{array}$ & $\begin{array}{c}\text { Land area, } \\
\text { in percent } \\
\text { of total } \\
\text { for crop }\end{array}$ & $\begin{array}{l}\text { Land area, } \\
\text { in } \mathrm{Ma}\end{array}$ & $\begin{array}{l}\text { Land area, } \\
\text { in } \mathbf{k k m}^{2}\end{array}$ & $\begin{array}{c}\text { Land area, } \\
\text { in percent } \\
\text { of total } \\
\text { for crop }\end{array}$ & $\begin{array}{l}\text { Land area, } \\
\text { in } \mathrm{Ma}\end{array}$ & $\begin{array}{l}\text { Land area, } \\
\text { in } \mathbf{k k m}^{2}\end{array}$ & $\begin{array}{c}\text { Land area, } \\
\text { in percent } \\
\text { of total } \\
\text { for crop }\end{array}$ & $\begin{array}{l}\text { Land area, } \\
\text { in Ma }\end{array}$ & $\begin{array}{c}\text { Land area, } \\
\text { in } \mathbf{k k m}^{2}\end{array}$ & $\begin{array}{c}\text { Land area, } \\
\text { in percent } \\
\text { of total } \\
\text { for crop }\end{array}$ \\
\hline Corn & 8.87 & 35.89 & 11.02 & 39.97 & 161.76 & 49.67 & 27.83 & 112.61 & 34.58 & 3.81 & 15.42 & 4.73 & 0.00 & 0.00 & 0.00 \\
\hline Soybeans & 5.24 & 21.21 & 7.00 & 30.83 & 124.76 & 41.16 & 30.04 & 121.59 & 40.12 & 8.78 & 35.53 & 11.72 & 0.00 & 0.00 & 0.00 \\
\hline Wheat & 31.42 & 127.18 & 60.13 & 18.24 & 73.82 & 34.90 & 2.33 & 9.45 & 4.47 & 0.26 & 1.06 & 0.50 & 0.00 & 0.00 & 0.00 \\
\hline Other crops & 6.78 & 27.44 & 56.95 & 1.70 & 6.86 & 14.24 & 1.66 & 6.74 & 13.98 & 1.76 & 7.14 & 14.81 & 0.00 & 0.01 & 0.03 \\
\hline Cotton & 4.13 & 16.69 & 43.95 & 1.78 & 7.22 & 19.01 & 1.76 & 7.11 & 18.72 & 1.72 & 6.96 & 18.33 & 0.00 & 0.00 & 0.00 \\
\hline Sorghum & 1.64 & 6.63 & 25.92 & 4.03 & 16.29 & 63.70 & 0.57 & 2.30 & 9.00 & 0.09 & 0.35 & 1.39 & 0.00 & 0.00 & 0.00 \\
\hline Vegetables and ground fruit & 3.04 & 12.31 & 64.23 & 1.02 & 4.14 & 21.59 & 0.56 & 2.27 & 11.84 & 0.11 & 0.45 & 2.34 & 0.00 & 0.00 & 0.00 \\
\hline Rice & 0.41 & 1.65 & 12.15 & 0.18 & 0.73 & 5.36 & 1.26 & 5.08 & 37.51 & 1.51 & 6.09 & 44.97 & 0.00 & 0.00 & 0.00 \\
\hline Orchards and grapes & 1.84 & 7.47 & 71.40 & 0.38 & 1.53 & 14.64 & 0.25 & 1.00 & 9.55 & 0.11 & 0.46 & 4.39 & 0.00 & 0.00 & 0.02 \\
\hline Citrus & 0.15 & 0.60 & 12.10 & 0.00 & 0.01 & 0.22 & 0.52 & 2.10 & 42.07 & 0.56 & 2.27 & 45.60 & 0.00 & 0.00 & 0.00 \\
\hline All crops & 63.50 & 256.99 & 25.69 & 98.14 & 397.19 & 39.71 & 66.77 & 270.26 & 27.02 & 18.71 & 75.73 & 7.57 & 0.00 & 0.02 & 0.00 \\
\hline
\end{tabular}


could be tagged as an area in decline. The polygon areas of groundwater-level decline also were converted to a raster dataset. The Well raster and Area raster datasets were combined to generate a map showing areas of groundwater-level decline.
The combined dataset was then combined with the 2009 Cropland Data Layer so that cropland in areas of groundwater-level decline could be identified (fig. 14, lower map).

Table 4-3. Optimal and sub-optimal heat and water requirements for selected crops.

[Sources: Fischer and others, 2002, Appendix IV, Temperature regime requirements of crops/LUTs; Brouwer and Heibloem, 1986, chapter 3, Crop water needs, 3.3.4, Indicative values of crop water needs. $\mathrm{mm} / \mathrm{yr}$, millimeters per year]

\begin{tabular}{lcccc}
\hline \multicolumn{1}{c}{ Crop } & $\begin{array}{c}\text { Sub-optimal heat } \\
\text { requirements, } \\
\text { in accumulated } \\
\text { growing degree-days }\end{array}$ & $\begin{array}{c}\text { Optimal heat } \\
\text { requirements, } \\
\text { in accumulated } \\
\text { growing degree-days }\end{array}$ & $\begin{array}{c}\text { Sub-optimal water } \\
\text { requirements, } \\
\text { in mm/yr }\end{array}$ & $\begin{array}{c}\text { Optimal water } \\
\text { requirements, } \\
\text { in } \mathbf{~ m m / y r ~}\end{array}$ \\
\hline Corn (Maize sub-tropics) & 1,900 & 2,400 & 500 & 800 \\
Soybeans & 1,700 & 2,000 & 450 & 700 \\
Wheat (winter) & 1,200 & 1,300 & 450 & 650 \\
Wheat (spring) & 1,400 & 1,800 & 450 & 650 \\
Cotton & 2,700 & 3,000 & 700 & 1,300 \\
Sorghum (lowland sorghum) & 2,200 & 2,500 & 450 & 650 \\
Rice (Indica, wetland-southern U.S.) & 2,400 & 3,000 & 450 & 700 \\
Rice (Japonica, wetland-California ) & 1,800 & 2,200 & 450 & 700 \\
\hline
\end{tabular}

Table 4-4. Total irrigated acreage for selected crops for 2007 for the conterminous United States (U.S. Department of Agriculture, 2009a).

[ $\mathrm{km}^{2}$, square kilometers; USDA, U.S. Department of Agriculture]

\begin{tabular}{lcccccc}
\hline \multicolumn{1}{c}{ Crop } & $\begin{array}{c}\text { Total area, } \\
\text { in acres }\end{array}$ & $\begin{array}{c}\text { Total area, } \\
\text { in } \mathbf{~ k m}^{2}\end{array}$ & $\begin{array}{c}\text { Irrigated area, } \\
\text { in acres }\end{array}$ & $\begin{array}{c}\text { Irrigated area, } \\
\text { in km }{ }^{2}\end{array}$ & $\begin{array}{c}\text { Irrigated area, } \\
\text { in percent }\end{array}$ & $\begin{array}{c}\text { USDA } \\
\text { Map Number }\end{array}$ \\
\hline Corn & $86,248,542$ & 349,035 & $13,156,769$ & 53,244 & 15 & $07-\mathrm{M} 164$ \\
Soybeans & $63,915,821$ & 258,658 & $5,237,075$ & 21,194 & 8 & $07-\mathrm{M} 194$ \\
Wheat & $50,932,969$ & 206,118 & $3,364,079$ & 13,614 & 7 & $07-\mathrm{M} 173$ \\
Cotton & $10,493,238$ & 42,465 & $4,035,610$ & 16,332 & 38 & $07-\mathrm{M} 186$ \\
Sorghum & $6,769,834$ & 27,397 & 845,214 & 3,420 & 12 & $07-\mathrm{M} 169$ \\
Rice & $2,758,792$ & 11,164 & $2,758,792$ & 11,164 & 100 & $07-\mathrm{M} 180$ \\
Vegetables & $4,682,588$ & 18,950 & $3,068,485$ & 12,418 & 66 & $07-\mathrm{M} 218$ \\
Orchards & $5,039,476$ & 20,394 & $3,981,316$ & 16,112 & 79 & $07-\mathrm{M} 233$ \\
\hline
\end{tabular}




\section{Appendix 5-Soil}

Dot density maps are used to show the distribution of cropland treated with commercial fertilizer, lime, and soil conditioners, as well as cropland treated with manure (fig. 15). These maps (Map Numbers 07-M103 and 07-M105) are available from the 2007 Census of Agriculture (U.S. Department of Agriculture, 2009b). These maps are not available as digital datasets in this report and were used simply to illustrate the primary extent of treated cropland.

The percentage of cropland acres treated with nitrogen, phosphate, and potash for selected crops (fig. 15) was obtained from fertilizer use data estimated by the Economic Research Service (U.S. Department of Agriculture, 2010a). The average annual percentage of cropland acres treated was calculated for 1989-2007.

The soils capability class and hazard class data were obtained from the U.S. Department of Agriculture (2006) U.S. General Soils Map (STATSGO) dataset. The dataset consists of tabular data in Microsoft Access format and vector spatial data. The spatial data consists of soils-association polygons identified by a unique map unit (MUKEY) code. The MUKEY is used to relate the spatial data to the tabular data. Each soils association consists of two or more major soil components that occur together in a similar pattern so that the patterns and proportions of major soils are alike within a single association. The Component table includes soil properties for all the soil components in the United States and can be linked to the soils associations through the MUKEY.

Capability class and hazard class are soil properties available in the Component table. The major soil component (the largest areal extent within a soils association) was used to assign a capability class and hazard class for each soilsassociation polygon. The definitions for land capability class and hazard class are described by Helms (1992) and are listed in table 5-1. To determine the amount of cropland in each class (fig. 16), the soils capability class was assigned to each soils-association polygon for the United States, converted to a 56-m-cell-size raster dataset, and combined with the 2009 Cropland Data Layer to calculate the percentage of land area in each crop group for each land capability class (I, II, III, IV, and V-VIII) (table 5-1). The combined raster dataset was used to generate a map showing the location of cropland on soils with severe or very severe limitations that require special conservation or management practices (fig. 17). 
Table 5-1. Land area in each crop or crop group for each land capability class in the 2009 Cropland Data Layer for the conterminous United States (U.S. Department of Agriculture, 2006, 2010b).

[Ma, million acres; $\mathrm{kkm}^{2}$, thousand square kilometers]

\begin{tabular}{|c|c|c|c|c|c|c|c|c|c|c|c|c|c|c|c|}
\hline \multirow{2}{*}{$\begin{array}{l}\text { Land capability class } \\
\text { Crop or crop group }\end{array}$} & \multicolumn{3}{|c|}{ I } & \multicolumn{3}{|c|}{ II } & \multicolumn{3}{|c|}{ III } & \multicolumn{3}{|c|}{ IV } & \multicolumn{3}{|c|}{ V, VI, VII, and VIII } \\
\hline & $\begin{array}{l}\text { Land area, } \\
\text { in } \mathrm{Ma}\end{array}$ & $\begin{array}{c}\text { Land area, } \\
\text { in } \mathbf{k k m}^{2}\end{array}$ & $\begin{array}{c}\text { Land area, } \\
\text { in percent } \\
\text { of total } \\
\text { for crop }\end{array}$ & $\begin{array}{l}\text { Land area, } \\
\text { in } \mathrm{Ma}\end{array}$ & $\begin{array}{c}\text { Land area, } \\
\text { in } \mathbf{k k m}^{2}\end{array}$ & $\begin{array}{c}\text { Land area, } \\
\text { in percent } \\
\text { of total } \\
\text { for crop }\end{array}$ & $\begin{array}{l}\text { Land area, } \\
\text { in Ma }\end{array}$ & $\begin{array}{c}\text { Land area, } \\
\text { in } \mathbf{k k m}^{2}\end{array}$ & $\begin{array}{c}\text { Land area, } \\
\text { in percent } \\
\text { of total } \\
\text { for crop }\end{array}$ & $\begin{array}{l}\text { Land area, } \\
\text { in } \mathrm{Ma}\end{array}$ & $\begin{array}{l}\text { Land area, } \\
\text { in } \mathbf{k k m}^{2}\end{array}$ & $\begin{array}{c}\text { Land area, } \\
\text { in percent } \\
\text { of total } \\
\text { for crop }\end{array}$ & $\begin{array}{l}\text { Land area, } \\
\text { in } \mathrm{Ma}\end{array}$ & $\begin{array}{l}\text { Land area, } \\
\text { in } \mathbf{k k m}^{2}\end{array}$ & $\begin{array}{c}\text { Land area, } \\
\text { in percent } \\
\text { of total } \\
\text { for crop }\end{array}$ \\
\hline Corn & 7.27 & 29.42 & 9.03 & 42.87 & 173.48 & 53.26 & 20.26 & 81.97 & 25.17 & 5.30 & 21.46 & 6.59 & 4.78 & 19.36 & 5.94 \\
\hline Soybeans & 6.65 & 26.91 & 8.88 & 40.32 & 163.19 & 53.84 & 19.23 & 77.81 & 25.67 & 4.80 & 19.41 & 6.40 & 3.90 & 15.77 & 5.20 \\
\hline Wheat & 1.24 & 5.00 & 2.36 & 20.57 & 83.26 & 39.37 & 18.02 & 72.91 & 34.47 & 7.27 & 29.42 & 13.91 & 5.17 & 20.91 & 9.89 \\
\hline Other crops & 0.56 & 2.25 & 4.66 & 4.59 & 18.56 & 38.51 & 3.25 & 13.15 & 27.28 & 1.59 & 6.45 & 13.38 & 1.93 & 7.79 & 16.17 \\
\hline Cotton & 0.70 & 2.82 & 7.41 & 2.30 & 9.32 & 24.52 & 4.09 & 16.54 & 43.54 & 1.16 & 4.70 & 12.37 & 1.14 & 4.62 & 12.16 \\
\hline Sorghum & 0.17 & 0.68 & 2.67 & 3.06 & 12.38 & 48.43 & 2.23 & 9.02 & 35.29 & 0.45 & 1.82 & 7.12 & 0.41 & 1.66 & 6.49 \\
\hline Vegetables and ground fruit & 0.08 & 0.32 & 1.69 & 1.68 & 6.79 & 35.42 & 0.93 & 3.76 & 19.63 & 0.71 & 2.89 & 15.07 & 1.33 & 5.40 & 28.19 \\
\hline Rice & 0.07 & 0.28 & 2.04 & 0.69 & 2.79 & 20.63 & 1.86 & 7.50 & 55.38 & 0.64 & 2.57 & 18.98 & 0.10 & 0.40 & 2.96 \\
\hline Orchards and grapes & 0.04 & 0.17 & 1.61 & 0.21 & 0.83 & 7.95 & 0.68 & 2.75 & 26.30 & 1.04 & 4.20 & 40.12 & 0.62 & 2.51 & 24.03 \\
\hline Citrus & 0.00 & 0.00 & 0.00 & 0.00 & 0.01 & 0.14 & 0.36 & 1.46 & 29.27 & 0.77 & 3.12 & 62.71 & 0.10 & 0.39 & 7.89 \\
\hline All crops & 16.77 & 67.87 & 6.79 & 116.28 & 470.63 & 47.05 & 70.89 & 286.91 & 28.69 & 23.72 & 95.99 & 9.60 & 19.47 & 78.79 & 7.88 \\
\hline
\end{tabular}

Class I soils have slight limitations that restrict their use.

Class II soils have moderate limitations that reduce the choice of plants or require moderate conservation practices.

Class III soils have severe limitations that reduce the choice of plants or require special conservation practices or both.

Class IV soils have very severe limitations that restrict the choice of plants or require very careful management or both.

Class V, VI, VII, and VIII soils have very severe limitations that make them unsuited to cultivation. 


\section{Appendix 6-Soil Water}

Soil hazard class (also called soil sub-class) was used to show soils where the dominant hazard is from climate, soil limitations, erosion, or excess water. The methods for determining soil hazard class for cropland is the same as the method for determining soils capability class as explained in appendix 5. To determine the amount of cropland in each hazard class (fig. 18), the class was assigned to each soilsassociation polygon, converted to a 56-m-cell-size raster dataset, and combined with the 2009 Cropland Data Layer to calculate the percentage of land area in each crop group for each land capability hazard class (Climate, Soil, Erosion, and Water) (table 6-1). The combined raster dataset was used to generate a map showing the location of cropland on soils in each hazard class (fig. 19).

Soils hazard Water was used to determine areas where artificial drainage is likely needed to support agriculture. Artificial drainage includes both surface drainage (manmade ditches and canals) and subsurface drainage (tile drains). Specific information about the location of ditches and tile drains was not available at the time of this writing. Jaynes and James (2007) found that using this soil hazard class with row crops is a reasonable estimate of where artificial drainage will be. In reality, drainage may be placed in areas that are not in the soil hazard class Water and, conversely, not all cultivated land in the soil hazard class Water is drained. The illustrations and charts in figure 20 are used to show the areas likely requiring drainage to remove excess water in order to cultivate cropland.

Further differentiation of hazard class Water for soils likely using either surface or subsurface drainage was determined by overlaying artificial drainage raster dataset with the 1992 Natural Resources Inventory county-level conservation practice raster dataset (c606 - subsurface drainage and c607surface drainage, field ditches) (Michael Wieczorek, U.S. Geological Survey, written commun., 2010). This was done to generate the surface- and subsurface-drainage maps in figure 20 so that the reader can get a general idea of the locations where each type of artificial drainage is predominant. The value of each cell in the raster dataset represents the estimated percentage of the $1-\mathrm{km}$ cell that is covered by or subject to a particular agricultural practice, on agricultural land by county. Federal Lands are excluded from the set and are designated as NODATA. (Data from 1992 are available at $h t t p: / / w a t e r u s g s$. gov/GIS/metadata/usgswrd/XML/ofr041189606.xml.)

To determine the amount of cropland that is likely either artificially drained or not artificially drained (fig. 20, bar graph), the soils hazard class raster dataset for Water was converted to a 56-m-cell-size raster dataset and combined with the 2009 Cropland Data Layer to calculate the percentage of land area in each crop group that is artificially drained and all other cropland not artificially drained (table 6-2). The National Resources Inventory dataset was not at high enough resolution to differentiate the amount of cropland artificially drained by surface or subsurface methods.

Average annual runoff and recharge (1971-2000) are spatial datasets provided by David Wolock (U.S. Geological Survey, written commun., 2010). The 1951-1980 data were previously published for runoff (Gebert and others, 1987) and for recharge (Wolock, 2003). Methods used to generate the 1951-1980 datasets are described in the metadata of the dataset and are the same methods used to generate the 1971-2000 datasets.

The recharge map (fig. 22) is an index of long-term average natural groundwater recharge, and it was created by multiplying a raster of base-flow index values by a raster of average annual runoff values derived from a 1971-2000 average annual runoff contour map. Average annual runoff is long-term average streamflow expressed on a per-unit-area basis. The concept used to construct the dataset is based on two assumptions: (1) long-term average natural groundwater recharge is equal to long-term average natural groundwater discharge to streams, and (2) the base-flow index reasonably represents, over the long term, the percentage of natural ground-water discharge in streamflow (Wolock, 2003).

To determine the amount of cropland for each runoff and recharge range (figs. 21 and 22) the spatial data were converted to a 56-m raster dataset and combined with the 2009 Cropland Data Layer to calculate the percentage of land area in each crop group for each runoff and recharge range (tables 6-3 and 6-4). 
Table 6-1. Land area in each crop or crop group for each land hazard class in the 2009 Cropland Data Layer for the conterminous United States (U.S. Department of Agriculture, 2006, 2010b).

[Ma, million acres; $\mathrm{kkm}^{2}$, thousand square kilometers]

\begin{tabular}{|c|c|c|c|c|c|c|c|c|c|c|c|c|c|c|c|}
\hline Land hazard class & & Undefined & & & Climate & & & Erosion & & & Soils & & & Water & \\
\hline Crop or crop group & $\begin{array}{c}\text { Land area, } \\
\text { in } \mathrm{Ma}\end{array}$ & $\begin{array}{c}\text { Land area, } \\
\text { in } \mathbf{k k m}^{2}\end{array}$ & $\begin{array}{c}\text { Land area, } \\
\text { in percent } \\
\text { of total } \\
\text { for crop }\end{array}$ & $\begin{array}{l}\text { Land area, } \\
\text { in } \mathrm{Ma}\end{array}$ & $\begin{array}{c}\text { Land area, } \\
\text { in } \mathbf{k k m}^{2}\end{array}$ & $\begin{array}{c}\text { Land area, } \\
\text { in percent } \\
\text { of total } \\
\text { for crop }\end{array}$ & $\begin{array}{l}\text { Land area, } \\
\text { in } \mathrm{Ma}\end{array}$ & $\begin{array}{c}\text { Land area, } \\
\text { in } \mathbf{k k m}^{2}\end{array}$ & $\begin{array}{c}\text { Land area, } \\
\text { in percent } \\
\text { of total } \\
\text { for crop }\end{array}$ & $\begin{array}{l}\text { Land area, } \\
\text { in } \mathrm{Ma}\end{array}$ & $\begin{array}{c}\text { Land area, } \\
\text { in } \mathbf{k k m}^{2}\end{array}$ & $\begin{array}{c}\text { Land area, } \\
\text { in percent } \\
\text { of total } \\
\text { for crop }\end{array}$ & $\begin{array}{l}\text { Land area, } \\
\text { in } \mathrm{Ma}\end{array}$ & $\begin{array}{l}\text { Land area, } \\
\text { in } \mathbf{k k m}^{2}\end{array}$ & $\begin{array}{c}\text { Land area, } \\
\text { in percent } \\
\text { of total } \\
\text { for crop }\end{array}$ \\
\hline Corn & 7.48 & 30.29 & 9.30 & 4.09 & 16.53 & 5.08 & 42.07 & 170.24 & 52.27 & 5.65 & 22.85 & 7.01 & 21.20 & 85.78 & 26.34 \\
\hline Soybeans & 6.91 & 27.96 & 9.23 & 2.21 & 8.93 & 2.95 & 34.07 & 137.89 & 45.49 & 4.08 & 16.50 & 5.44 & 27.63 & 111.81 & 36.89 \\
\hline Wheat & 1.33 & 5.39 & 2.55 & 8.56 & 34.63 & 16.37 & 33.96 & 137.44 & 64.98 & 4.41 & 17.84 & 8.43 & 4.01 & 16.21 & 7.66 \\
\hline Other crops & 0.65 & 2.63 & 5.46 & 1.79 & 7.24 & 15.02 & 5.70 & 23.08 & 47.90 & 1.42 & 5.76 & 11.96 & 2.34 & 9.47 & 19.66 \\
\hline Cotton & 0.70 & 2.85 & 7.49 & 0.55 & 2.23 & 5.86 & 5.41 & 21.87 & 57.56 & 0.99 & 4.00 & 10.53 & 1.74 & 7.05 & 18.55 \\
\hline Sorghum & 0.18 & 0.72 & 2.82 & 1.39 & 5.64 & 22.05 & 3.41 & 13.79 & 53.94 & 0.85 & 3.44 & 13.47 & 0.49 & 1.97 & 7.72 \\
\hline Vegetables and ground fruit & 0.12 & 0.48 & 2.50 & 0.72 & 2.90 & 15.13 & 2.34 & 9.46 & 49.39 & 0.74 & 3.00 & 15.64 & 0.82 & 3.32 & 17.34 \\
\hline Rice & 0.07 & 0.30 & 2.19 & 0.03 & 0.11 & 0.81 & 0.20 & 0.80 & 5.92 & 0.13 & 0.51 & 3.73 & 2.93 & 11.83 & 87.35 \\
\hline Orchards and grapes & 0.05 & 0.19 & 1.85 & 0.83 & 3.37 & 32.18 & 0.65 & 2.63 & 25.12 & 0.80 & 3.24 & 30.93 & 0.26 & 1.04 & 9.93 \\
\hline Citrus & 0.00 & 0.01 & 0.14 & 0.05 & 0.21 & 4.18 & 0.05 & 0.20 & 4.11 & 0.29 & 1.18 & 23.68 & 0.84 & 3.38 & 67.89 \\
\hline All crops & 17.39 & 70.38 & 7.04 & 20.07 & 81.23 & 8.12 & 127.02 & 514.11 & 51.40 & 19.22 & 77.78 & 7.78 & 61.81 & 250.19 & 25.01 \\
\hline
\end{tabular}

Climate class is made up of soils for which the climate - the temperature or lack of moisture — is the major hazard or limitation.

Erosion class is made up of soils for which the susceptibility to erosion is the dominant problem or hazard affecting their use. Erosion susceptibility and past erosion damage are the major soil factors that affect soils in this subclass.

Soils class is made up of soils that have soil limitations within the rooting zone, such as shallowness of the rooting zone, stones, low moisture-holding capacity, low fertility that is difficult to correct, and salinity or sodium content.

Water class is made up of soils for which excess water is the dominant hazard or limitation affecting their use. Poor soil drainage, wetness, a high water table, and overflow are factors that affect these soils. 
Table 6-2. Land area in each crop or crop group that is artificially drained in the 2009 Cropland Data Layer for the conterminous United States (U.S. Department of Agriculture, 2006,2010b; Michael Wieczorek, U.S. Geological Survey, written commun., 2010).

[Ma, million acres; $\mathrm{kkm}^{2}$, thousand square kilometers]

\begin{tabular}{|c|c|c|c|c|c|c|}
\hline \multirow[b]{2}{*}{ Crop or crop group } & \multicolumn{3}{|c|}{ Not artificially drained } & \multicolumn{3}{|c|}{ Artificially drained } \\
\hline & $\begin{array}{l}\text { Land area, } \\
\text { in } \mathrm{Ma}\end{array}$ & $\begin{array}{l}\text { Land area, } \\
\text { in } \mathbf{k k m}^{2}\end{array}$ & $\begin{array}{l}\text { Land area, } \\
\text { in percent } \\
\text { of total } \\
\text { for crop }\end{array}$ & $\begin{array}{l}\text { Land area, } \\
\text { in } \mathrm{Ma}\end{array}$ & $\begin{array}{l}\text { Land area, } \\
\text { in } \mathbf{k k m}^{2}\end{array}$ & $\begin{array}{c}\text { Land area, } \\
\text { in percent } \\
\text { of total } \\
\text { for crop }\end{array}$ \\
\hline Corn & 59.19 & 239.54 & 73.55 & 21.29 & 86.15 & 26.45 \\
\hline Soybeans & 47.23 & 191.15 & 63.07 & 27.66 & 111.94 & 36.93 \\
\hline Wheat & 48.27 & 195.37 & 92.37 & 3.99 & 16.14 & 7.63 \\
\hline Other crops & 9.56 & 38.69 & 80.29 & 2.35 & 9.50 & 19.71 \\
\hline Cotton & 7.65 & 30.95 & 81.47 & 1.74 & 7.04 & 18.53 \\
\hline Sorghum & 5.82 & 23.54 & 92.07 & 0.50 & 2.03 & 7.93 \\
\hline Vegetables and ground fruit & 3.91 & 15.83 & 82.64 & 0.82 & 3.33 & 17.36 \\
\hline Rice & 0.41 & 1.64 & 12.12 & 2.94 & 11.90 & 87.88 \\
\hline Orchards and grapes & 2.32 & 9.42 & 90.01 & 0.26 & 1.04 & 9.99 \\
\hline Citrus & 0.41 & 1.64 & 32.99 & 0.82 & 3.34 & 67.01 \\
\hline All crops & 184.76 & 747.79 & 74.77 & 62.36 & 252.39 & 25.23 \\
\hline
\end{tabular}


Table 6-3. Land area in each crop or crop group for each runoff category in the 2009 Cropland Data Layer for the conterminous United States (David M. Wolock. U.S. Geological Survey, written commun. 2009; U.S. Department of Agriculture, 2010b).

[mm/y, millimeters per year, Ma, million acres; $\mathrm{kkm}^{2}$, thousand square kilometers]

\begin{tabular}{|c|c|c|c|c|c|c|c|c|c|c|c|c|c|c|c|}
\hline \multirow{2}{*}{$\begin{array}{c}\text { Runoff category, in mm/yr } \\
\text { Crop or crop group }\end{array}$} & \multicolumn{3}{|c|}{0 to 214} & \multicolumn{3}{|c|}{$>214$ to 628} & \multicolumn{3}{|c|}{$>628$ to 1,355} & \multicolumn{3}{|c|}{$>1,255$ to 2,976} & \multicolumn{3}{|c|}{$>2,976$} \\
\hline & $\begin{array}{c}\text { Land area, } \\
\text { in Ma }\end{array}$ & $\begin{array}{c}\text { Land area, } \\
\text { in } \mathbf{k k m}^{2}\end{array}$ & $\begin{array}{l}\text { Land area, } \\
\text { in percent } \\
\text { of total } \\
\text { for crop }\end{array}$ & $\begin{array}{c}\text { Land area, } \\
\text { in } \mathrm{Ma}\end{array}$ & $\begin{array}{c}\text { Land area, } \\
\text { in } \mathbf{k k m}^{2}\end{array}$ & $\begin{array}{c}\text { Land area, } \\
\text { in percent } \\
\text { of total } \\
\text { for crop }\end{array}$ & $\begin{array}{l}\text { Land area, } \\
\text { in } \mathrm{Ma}\end{array}$ & $\begin{array}{l}\text { Land area, } \\
\text { in } \mathbf{k k m}^{2}\end{array}$ & $\begin{array}{c}\text { Land area, } \\
\text { in percent } \\
\text { of total } \\
\text { for crop }\end{array}$ & $\begin{array}{l}\text { Land area, } \\
\text { in } \mathrm{Ma}\end{array}$ & $\begin{array}{c}\text { Land area, } \\
\text { in } \mathbf{k k m}^{2}\end{array}$ & $\begin{array}{c}\text { Land area, } \\
\text { in percent } \\
\text { of total } \\
\text { for crop }\end{array}$ & $\begin{array}{l}\text { Land area, } \\
\text { in Ma }\end{array}$ & $\begin{array}{c}\text { Land area, } \\
\text { in } \mathbf{k k m}^{2}\end{array}$ & $\begin{array}{l}\text { Land area, } \\
\text { in percent } \\
\text { of total } \\
\text { for crop }\end{array}$ \\
\hline Corn & 29.61 & 119.84 & 36.80 & 27.88 & 112.84 & 34.65 & 18.15 & 73.44 & 22.55 & 4.74 & 19.16 & 5.88 & 0.10 & 0.41 & 0.13 \\
\hline Soybeans & 27.21 & 110.13 & 36.34 & 27.75 & 112.32 & 37.06 & 16.74 & 67.73 & 22.35 & 3.14 & 12.71 & 4.19 & 0.05 & 0.20 & 0.07 \\
\hline Wheat & 44.25 & 179.08 & 84.67 & 5.19 & 21.01 & 9.93 & 2.21 & 8.94 & 4.23 & 0.53 & 2.15 & 1.02 & 0.08 & 0.34 & 0.16 \\
\hline Other crops & 6.55 & 26.49 & 54.96 & 2.13 & 8.63 & 17.91 & 1.45 & 5.85 & 12.15 & 1.65 & 6.66 & 13.81 & 0.14 & 0.56 & 1.17 \\
\hline Cotton & 6.39 & 25.86 & 68.07 & 1.05 & 4.25 & 11.18 & 1.53 & 6.21 & 16.34 & 0.40 & 1.60 & 4.22 & 0.02 & 0.07 & 0.19 \\
\hline Sorghum & 6.05 & 24.48 & 95.72 & 0.20 & 0.80 & 3.14 & 0.04 & 0.17 & 0.67 & 0.03 & 0.11 & 0.45 & 0.00 & 0.01 & 0.02 \\
\hline Vegetables and ground fruit & 2.42 & 9.79 & 51.10 & 0.89 & 3.61 & 18.87 & 0.90 & 3.66 & 19.12 & 0.48 & 1.93 & 10.06 & 0.04 & 0.16 & 0.86 \\
\hline Rice & 2.28 & 9.22 & 68.07 & 0.37 & 1.51 & 11.18 & 0.55 & 2.21 & 16.34 & 0.14 & 0.57 & 4.22 & 0.01 & 0.03 & 0.19 \\
\hline Orchards and grapes & 1.19 & 4.82 & 46.08 & 0.48 & 1.94 & 18.52 & 0.59 & 2.38 & 22.79 & 0.26 & 1.06 & 10.14 & 0.06 & 0.26 & 2.47 \\
\hline Citrus & 1.00 & 4.05 & 81.29 & 0.08 & 0.31 & 6.19 & 0.12 & 0.48 & 9.68 & 0.03 & 0.14 & 2.84 & 0.00 & 0.00 & 0.00 \\
\hline All crops & 125.28 & 507.04 & 50.70 & 66.89 & 270.74 & 27.07 & 43.02 & 174.14 & 17.41 & 11.43 & 46.25 & 4.62 & 0.50 & 2.01 & 0.20 \\
\hline
\end{tabular}


Table 6-4. Land area in each crop or crop group for each recharge category in the 2009 Cropland Data Layer for the conterminous United States (David M. Wolock, U.S. Geological Survey, written commun., 2009; U.S. Department of Agriculture, 2010b).

[mm/y, millimeters per year, Ma, million acres; $\mathrm{kkm}^{2}$, thousand square kilometers]

\begin{tabular}{|c|c|c|c|c|c|c|c|c|c|c|c|c|c|c|c|}
\hline Recharge category, in mm/yr & & 0 to 214 & & & $>214$ to 628 & & & $>628$ to 1,355 & & & 1,255 to 2,97 & & & $>2,976$ & \\
\hline Crop or crop group & $\begin{array}{l}\text { Land area, } \\
\text { in } \mathrm{Ma}\end{array}$ & $\begin{array}{l}\text { Land area, } \\
\text { in } \mathbf{k k m}^{2}\end{array}$ & $\begin{array}{c}\text { Land area, } \\
\text { in percent } \\
\text { of total } \\
\text { for crop }\end{array}$ & $\begin{array}{l}\text { Land area, } \\
\text { in Ma }\end{array}$ & $\begin{array}{l}\text { Land area, } \\
\text { in } \mathbf{k k m}^{2}\end{array}$ & $\begin{array}{c}\text { Land area, } \\
\text { in percent } \\
\text { of total } \\
\text { for crop }\end{array}$ & $\begin{array}{c}\text { Land area, } \\
\text { in Ma }\end{array}$ & $\begin{array}{c}\text { Land area, } \\
\text { in } \mathbf{k k m}^{2}\end{array}$ & $\begin{array}{c}\text { Land area, } \\
\text { in percent } \\
\text { of total } \\
\text { for crop }\end{array}$ & $\begin{array}{l}\text { Land area, } \\
\text { in } \mathrm{Ma}\end{array}$ & $\begin{array}{l}\text { Land area, } \\
\text { in } \mathbf{k k m}^{2}\end{array}$ & $\begin{array}{c}\text { Land area, } \\
\text { in percent } \\
\text { of total } \\
\text { for crop }\end{array}$ & $\begin{array}{l}\text { Land area, } \\
\text { in } \mathrm{Ma}\end{array}$ & $\begin{array}{l}\text { Land area, } \\
\text { in } \mathbf{k k m}^{2}\end{array}$ & $\begin{array}{c}\text { Land area, } \\
\text { in percent } \\
\text { of total } \\
\text { for crop }\end{array}$ \\
\hline Corn & 59.48 & 240.70 & 73.91 & 16.15 & 65.34 & 20.06 & 4.46 & 18.04 & 5.54 & 0.34 & 1.39 & 0.43 & 0.05 & 0.22 & 0.07 \\
\hline Soybeans & 49.81 & 201.60 & 66.51 & 19.14 & 77.45 & 25.55 & 5.64 & 22.81 & 7.52 & 0.27 & 1.11 & 0.37 & 0.03 & 0.12 & 0.04 \\
\hline Wheat & 37.03 & 149.86 & 70.85 & 12.57 & 50.88 & 24.05 & 2.55 & 10.33 & 4.88 & 0.11 & 0.44 & 0.21 & 0.00 & 0.01 & 0.00 \\
\hline Other crops & 10.75 & 43.48 & 90.22 & 0.89 & 3.60 & 7.47 & 0.24 & 0.97 & 2.01 & 0.02 & 0.09 & 0.18 & 0.01 & 0.06 & 0.12 \\
\hline Cotton & 5.97 & 24.15 & 63.58 & 2.02 & 8.19 & 21.55 & 1.15 & 4.66 & 12.27 & 0.24 & 0.96 & 2.53 & 0.01 & 0.02 & 0.06 \\
\hline Sorghum & 4.91 & 19.86 & 77.66 & 1.02 & 4.14 & 16.18 & 0.33 & 1.32 & 5.16 & 0.06 & 0.26 & 1.01 & 0.00 & 0.00 & 0.00 \\
\hline Vegetables and ground fruit & 4.66 & 18.89 & 98.61 & 0.05 & 0.22 & 1.15 & 0.01 & 0.04 & 0.21 & 0.00 & 0.01 & 0.03 & 0.00 & 0.00 & 0.00 \\
\hline Rice & 2.02 & 8.16 & 60.26 & 0.84 & 3.39 & 25.00 & 0.43 & 1.74 & 12.87 & 0.05 & 0.20 & 1.50 & 0.01 & 0.05 & 0.37 \\
\hline Orchards and grapes & 1.73 & 7.01 & 67.03 & 0.79 & 3.19 & 30.54 & 0.06 & 0.25 & 2.43 & 0.00 & 0.00 & 0.00 & 0.00 & 0.00 & 0.00 \\
\hline Citrus & 0.78 & 3.16 & 63.46 & 0.29 & 1.18 & 23.71 & 0.12 & 0.48 & 9.58 & 0.02 & 0.08 & 1.59 & 0.02 & 0.08 & 1.66 \\
\hline All crops & 102.72 & 415.75 & 41.57 & 11.93 & 48.28 & 4.83 & 3.18 & 12.89 & 1.29 & 0.00 & 0.00 & 0.00 & 0.00 & 0.00 & 0.00 \\
\hline
\end{tabular}




\section{Appendix 7-Other Land Uses in Competition for Agricultural Lands}

The Potential Natural Vegetation (PNV) map was generalized by grouping PNV classes into Broadleaf Forests, Needleleaf Forests, Grasslands, and Scrublands (Missoula Fire Sciences Laboratory, 2001). Wetland areas are not a category on the PNV map and were added by combining Water hazard class soils (see Appendix 6, table 6-1) to the PNV (U.S. Department of Agriculture, 2006).
To determine the amount of cropland that has been converted from the "natural" state, the PNV polygons were converted to a 56-m raster dataset and first combined with the Water-hazard-class soils. The resulting raster dataset was then combined with the 2009 Cropland Data Layer to calculate the percentage of "natural" land area that has converted to each crop (tables 7-1, 7-2, and 7-3; fig. 23). 
Table 7-1. Land area in each potential natural vegetation type converted to cropland, and grassland and hay for the conterminous United States (Missoula Fire Sciences Laboratory, 2001; U.S. Department of Agriculture, 2006).

[Ma, million acres; $\mathrm{kkm}^{2}$, thousand square kilometers]

\begin{tabular}{|c|c|c|c|c|c|c|c|c|c|c|c|c|c|c|c|}
\hline \multirow{2}{*}{$\begin{array}{c}\begin{array}{c}\text { Potential natural } \\
\text { vegetation type }\end{array} \\
\text { Crop or crop group }\end{array}$} & \multicolumn{3}{|c|}{ Wetlands } & \multicolumn{3}{|c|}{ Broadleaf forests } & \multicolumn{3}{|c|}{ Needleleaf forests } & \multicolumn{3}{|c|}{ Grasslands } & \multicolumn{3}{|c|}{ Shrublands } \\
\hline & $\begin{array}{l}\text { Land area, } \\
\text { in Ma }\end{array}$ & $\begin{array}{l}\text { Land area, } \\
\text { in } \mathbf{k k m}^{2}\end{array}$ & $\begin{array}{c}\text { Land area, } \\
\text { in percent } \\
\text { of total } \\
\text { for crop }\end{array}$ & $\begin{array}{l}\text { Land area, } \\
\text { in } \mathrm{Ma}\end{array}$ & $\begin{array}{l}\text { Land area, } \\
\text { in } \mathbf{k k m}^{2}\end{array}$ & $\begin{array}{c}\text { Land area, } \\
\text { in percent } \\
\text { of total } \\
\text { for crop }\end{array}$ & $\begin{array}{l}\text { Land area, } \\
\text { in } \mathrm{Ma}\end{array}$ & $\begin{array}{l}\text { Land area, } \\
\text { in } \mathbf{k k m}^{2}\end{array}$ & $\begin{array}{c}\text { Land area, } \\
\text { in percent } \\
\text { of total } \\
\text { for crop }\end{array}$ & $\begin{array}{l}\text { Land area, } \\
\text { in } \mathrm{Ma}\end{array}$ & $\begin{array}{l}\text { Land area, } \\
\text { in } \mathbf{k k m}^{2}\end{array}$ & $\begin{array}{c}\text { Land area, } \\
\text { in percent } \\
\text { of total } \\
\text { for crop }\end{array}$ & $\begin{array}{l}\text { Land area, } \\
\text { in } \mathrm{Ma}\end{array}$ & $\begin{array}{l}\text { Land area, } \\
\text { in } \mathbf{k k m}^{2}\end{array}$ & $\begin{array}{c}\text { Land area, } \\
\text { in percent } \\
\text { of total } \\
\text { for crop }\end{array}$ \\
\hline $\begin{array}{l}\text { Total potential natural } \\
\text { vegetation land area }\end{array}$ & 246 & 995 & 13 & 511 & 2067 & 27 & 284 & 1148 & 15 & 549 & 2220 & 29 & 303 & 1225 & 16 \\
\hline $\begin{array}{l}\text { Potential natural vegetation } \\
\text { converted to cropland }\end{array}$ & 62 & 250 & 25 & 47 & 190 & 19 & 0 & 0 & 0 & 129 & 520 & 52 & 7 & 30 & 3 \\
\hline $\begin{array}{l}\text { Potential natural vegetation } \\
\text { converted to grassland } \\
\text { and hay }\end{array}$ & 43 & 176 & 9 & 106 & 429 & 22 & 29 & 117 & 6 & 265 & 1073 & 55 & 39 & 156 & 8 \\
\hline
\end{tabular}


Table 7-2. Land area in each crop or crop group for each potential natural vegetation type in the 2009 Cropland Data Layer for the conterminous United States (Missoula Fire Sciences Laboratory, 2001; U.S. Department of Agriculture, 2010b).

[Ma, million acres; $\mathrm{kkm}^{2}$, thousand square kilometers]

\begin{tabular}{|c|c|c|c|c|c|c|c|c|c|c|c|c|c|c|c|c|c|c|}
\hline \multirow{2}{*}{$\begin{array}{c}\begin{array}{c}\text { Potential } \\
\text { natural } \\
\text { vegetation } \\
\text { type }\end{array} \\
\begin{array}{c}\text { Crop or } \\
\text { crop group }\end{array}\end{array}$} & \multicolumn{3}{|c|}{ Wetlands } & \multicolumn{3}{|c|}{ Broadleaf forests } & \multicolumn{3}{|c|}{ Needleleaf forests } & \multicolumn{3}{|c|}{ Grasslands } & \multicolumn{3}{|c|}{ Shrublands } & \multicolumn{3}{|c|}{ Total cropland } \\
\hline & $\begin{array}{l}\text { Land area, } \\
\text { in } \mathrm{Ma}\end{array}$ & $\begin{array}{c}\text { Land area, } \\
\text { in } \mathbf{k k m}^{2}\end{array}$ & $\begin{array}{c}\text { Land area, } \\
\text { in percent } \\
\text { of total } \\
\text { for crop }\end{array}$ & $\begin{array}{l}\text { Land area, } \\
\text { in } \mathrm{Ma}\end{array}$ & $\begin{array}{l}\text { Land area, } \\
\text { in } \mathbf{k k m}^{2}\end{array}$ & $\begin{array}{c}\text { Land area, } \\
\text { in percent } \\
\text { of total } \\
\text { for crop }\end{array}$ & $\begin{array}{l}\text { Land area, } \\
\text { in } \mathrm{Ma}\end{array}$ & $\begin{array}{l}\text { Land area, } \\
\text { in } \mathbf{k k m}^{2}\end{array}$ & $\begin{array}{c}\text { Land area, } \\
\text { in percent } \\
\text { of total } \\
\text { for crop }\end{array}$ & $\begin{array}{l}\text { Land area, } \\
\text { in } \mathrm{Ma}\end{array}$ & $\begin{array}{l}\text { Land area, } \\
\text { in } \mathbf{k k m}^{2}\end{array}$ & $\begin{array}{c}\text { Land area, } \\
\text { in percent } \\
\text { of total } \\
\text { for crop }\end{array}$ & $\begin{array}{l}\text { Land area, } \\
\text { in } \mathrm{Ma}\end{array}$ & $\begin{array}{l}\text { Land area, } \\
\text { in } \mathbf{k k m}^{2}\end{array}$ & $\begin{array}{c}\text { Land area, } \\
\text { in percent } \\
\text { of total } \\
\text { for crop }\end{array}$ & $\begin{array}{l}\text { Land area, } \\
\text { in Ma }\end{array}$ & $\begin{array}{l}\text { Land area, } \\
\text { in } \mathbf{k k m}^{2}\end{array}$ & $\begin{array}{c}\text { Land area, } \\
\text { in percent } \\
\text { of total } \\
\text { for crop }\end{array}$ \\
\hline Corn & 20.92 & 84.68 & 26.00 & 19.32 & 78.17 & 24.00 & 0.80 & 3.26 & 1.00 & 38.63 & 156.33 & 48.00 & 0.80 & 3.26 & 1.00 & 80.48 & 325.69 & 100.00 \\
\hline Soybeans & 27.71 & 112.14 & 37.00 & 17.97 & 72.74 & 24.00 & 0.00 & 0.00 & 0.00 & 29.21 & 118.21 & 39.00 & 0.00 & 0.00 & 0.00 & 74.89 & 303.09 & 100.00 \\
\hline Wheat & 4.18 & 16.92 & 8.00 & 2.61 & 10.58 & 5.00 & 0.52 & 2.12 & 1.00 & 42.33 & 171.32 & 81.00 & 2.61 & 10.58 & 5.00 & 52.26 & 211.51 & 100.00 \\
\hline Other crops & 2.38 & 9.64 & 20.00 & 2.38 & 9.64 & 20.00 & 0.24 & 0.96 & 2.00 & 5.60 & 22.65 & 47.00 & 1.31 & 5.30 & 11.00 & 11.91 & 48.19 & 100.00 \\
\hline Cotton & 1.78 & 7.22 & 19.00 & 1.88 & 7.60 & 20.00 & 0.00 & 0.00 & 0.00 & 5.16 & 20.89 & 55.00 & 0.56 & 2.28 & 6.00 & 9.39 & 37.99 & 100.00 \\
\hline Sorghum & 0.51 & 2.05 & 8.00 & 0.32 & 1.28 & 5.00 & 0.00 & 0.00 & 0.00 & 4.80 & 19.43 & 76.00 & 0.70 & 2.81 & 11.00 & 6.32 & 25.57 & 100.00 \\
\hline $\begin{array}{l}\text { Vegetables } \\
\text { and } \\
\text { ground } \\
\text { fruit }\end{array}$ & 0.80 & 3.26 & 17.00 & 0.66 & 2.68 & 14.00 & 0.19 & 0.77 & 4.00 & 1.99 & 8.05 & 42.00 & 1.09 & 4.41 & 23.00 & 4.73 & 19.16 & 100.00 \\
\hline Rice & 2.95 & 11.92 & 88.00 & 0.23 & 0.95 & 7.00 & 0.00 & 0.00 & 0.00 & 0.17 & 0.68 & 5.00 & 0.00 & 0.00 & 0.00 & 3.35 & 13.54 & 100.00 \\
\hline $\begin{array}{c}\text { Orchards and } \\
\text { grapes }\end{array}$ & 0.26 & 1.05 & 10.00 & 0.57 & 2.30 & 22.00 & 0.05 & 0.21 & 2.00 & 1.37 & 5.54 & 53.00 & 0.34 & 1.36 & 13.00 & 2.58 & 10.46 & 100.00 \\
\hline Citrus & 0.82 & 3.34 & 67.00 & 0.31 & 1.25 & 25.00 & 0.00 & 0.00 & 0.00 & 0.09 & 0.35 & 7.00 & 0.01 & 0.05 & 1.00 & 1.23 & 4.98 & 100.00 \\
\hline All crops & 61.78 & 250.05 & 25.00 & 46.95 & 190.03 & 19.00 & 2.47 & 10.00 & 1.00 & 128.50 & 520.09 & 52.00 & 7.41 & 30.01 & 3.00 & 247.12 & $1,000.18$ & 100.00 \\
\hline $\begin{array}{l}\text { Grassland } \\
\text { and hay }\end{array}$ & 43.38 & 176.68 & 9.00 & 106.4 & 429.44 & 22.00 & 28.92 & 117.12 & 6.00 & 265.1 & $1,073.6$ & 55.00 & 38.56 & 156.16 & 8.00 & 482.00 & $1,953.00$ & 100.00 \\
\hline
\end{tabular}


Table 7-3. Land area for each potential natural vegetation class in cropland and in grassland.

$\left[\mathrm{kkm}^{2}\right.$, thousand square kilometers]

\begin{tabular}{|c|c|c|c|c|c|c|}
\hline $\begin{array}{c}\text { Natural vegetation } \\
\text { class }\end{array}$ & $\begin{array}{l}\text { Total land area } \\
\text { in class } \\
\left(\mathbf{k k m}^{2}\right)\end{array}$ & $\begin{array}{c}\text { Total cropland area } \\
\text { in class } \\
\left(\mathbf{k} \mathbf{k m}^{2}\right)^{\mathrm{a}}\end{array}$ & $\begin{array}{l}\text { Total grassland } \\
\text { and hay area } \\
\text { in class } \\
\left(\mathbf{k k m}^{2}\right)^{\mathrm{b}}\end{array}$ & $\begin{array}{l}\text { Percent of land } \\
\text { in class converted } \\
\text { to cropland } \\
(\%)\end{array}$ & $\begin{array}{c}\text { Percent of land } \\
\text { in class converted } \\
\text { to grassland and hay } \\
(\%)\end{array}$ & $\begin{array}{c}\text { Percent of } \\
\text { total agricultral } \\
\text { land } \\
(\%)\end{array}$ \\
\hline Broadleaf Forests & 2,092 & 190 & 429 & 9.1 & 20.5 & 21.0 \\
\hline Needleleaf Forests & 1,163 & 10 & 117 & 0.9 & 10.1 & 4.3 \\
\hline Wetland & 1,014 & 250 & 177 & 24.7 & 17.5 & 14.5 \\
\hline Shrublands & 1,271 & 30 & 156 & 2.4 & 12.3 & 6.3 \\
\hline All land & 7,748 & 1,000 & 1,953 & & & \\
\hline
\end{tabular}

${ }^{\text {a }}$ Not including grasslands and hay.

${ }^{\mathrm{b}}$ Grasslands converted to grassland; may or may not include lands that have been reseeded and otherwise disturbed. 


\section{Appendix 8-Summary of Data Sources and Online Links to Datasets}

The data sources used to generate this report and the associated online links to selected datasets are summarized in table $8-1$. An effort was made to use readily available data. In some cases, the data were not yet published and thus are cited as written communications. 
Table 8-1. Summary of data sources and online links to datasets.

$[\mathrm{m}$, meters $]$

\begin{tabular}{|c|c|c|c|c|c|c|c|c|}
\hline $\begin{array}{l}\text { Index } \\
\text { letter }\end{array}$ & Dataset name & Type of data & $\begin{array}{l}\text { Resolution (cell size) } \\
\text { in square meters }\end{array}$ & Scale & Figures & Tables & Reference & Link \\
\hline A & $\begin{array}{l}\text { Potential Natural } \\
\text { Vegetation }\end{array}$ & $\begin{array}{l}\text { Geospatial polygon } \\
\text { dataset }\end{array}$ & $\begin{array}{l}\text { Original map refined } \\
\text { to match 500-m } \\
\text { National Eleva- } \\
\text { tion Dataset }\end{array}$ & National & 1 & & $\begin{array}{l}\text { Missoula Fire Sci- } \\
\text { ences Laboratory, } \\
2001\end{array}$ & http://www.fs.fed.us/fire/fuelman/pnv.htm \\
\hline B & $\begin{array}{l}1790 \text { and } 1830 \text { Pop- } \\
\text { ulation Census }\end{array}$ & $\begin{array}{l}\text { Report (tabular data } \\
\text { from Norman Bliss, } \\
\text { U.S. Geological } \\
\text { Survey, written com- } \\
\text { mun., 2011) }\end{array}$ & & County & 2 & & $\begin{array}{l}\text { Waisanen and Bliss, } \\
2002\end{array}$ & $\begin{array}{l}\text { http://www.agu.org/pubs/ } \\
\quad \text { crossref/2002/2001GB001843.shtml }\end{array}$ \\
\hline $\mathrm{C}$ & $\begin{array}{l}\text { 1850-1997 Census } \\
\text { of Agriculture } \\
\text { (improved farm- } \\
\text { land) }\end{array}$ & $\begin{array}{l}\text { Report (tabular data } \\
\text { from Norman Bliss, } \\
\text { U.S. Geological } \\
\text { Survey, written com- } \\
\text { mun., 2011) }\end{array}$ & & County & 3 & & $\begin{array}{l}\text { Waisanen and Bliss, } \\
2002\end{array}$ & $\begin{array}{l}\text { http://www.agu.org/pubs/ } \\
\quad \text { crossref/2002/2001GB001843.shtml }\end{array}$ \\
\hline $\mathrm{D}$ & $\begin{array}{l}2002 \text { Census of } \\
\text { Agriculture } \\
\text { (county-level } \\
\text { total harvested } \\
\text { cropland) }\end{array}$ & Tabular dataset & & County & 3 & & $\begin{array}{l}\text { U.S. Department of } \\
\text { Agriculture, } 2005\end{array}$ & $\begin{array}{l}\text { http://www.agcensus.usda.gov/ } \\
\text { Publications/2002/index.asp }\end{array}$ \\
\hline $\mathrm{E}$ & $\begin{array}{l}\text { 1879-1997 Census } \\
\text { of Agriculture } \\
\text { (state-level crop- } \\
\text { land area) }\end{array}$ & $\begin{array}{l}\text { Report and tabular } \\
\text { dataset }\end{array}$ & & State & 4 & & $\begin{array}{l}\text { Ramankutty and } \\
\text { others, } 2010\end{array}$ & $\begin{array}{l}\text { http://www.informaworld.com } / \text { smpp/ftint } \\
\quad \text { erface } \sim d b=\text { all } \sim \text { content }=a 922418004 ? t \\
\quad a b=\text { multimedia }\end{array}$ \\
\hline $\mathrm{F}$ & $\begin{array}{l}2009 \text { Cropland Data } \\
\text { Layer }\end{array}$ & $\begin{array}{l}\text { Geospatial raster } \\
\text { dataset }\end{array}$ & $56 \mathrm{~m}$ & Local & 5 & $\begin{array}{l}\text { Appendix } 2 \text {, } \\
\text { tables } 2-1,2-2 \text {, } \\
2-3 \text {, and } 2-4\end{array}$ & $\begin{array}{l}\text { U.S. Department } \\
\text { of Agriculture, } \\
2010 \mathrm{~b}\end{array}$ & $\begin{array}{l}\text { http://www.nass.usda.gov/research/ } \\
\text { Cropland/SARSIa.htm }\end{array}$ \\
\hline G & $\begin{array}{l}\text { Major Uses of Land } \\
\text { in the United } \\
\text { States, } 2002\end{array}$ & Report & & National & & $\begin{array}{l}\text { Appendix } 2 \text {, table } \\
2-4\end{array}$ & $\begin{array}{l}\text { Lubowski and oth- } \\
\text { ers, } 2006\end{array}$ & $\begin{array}{l}\text { http://www.ers.usda.gov/Publications/ } \\
\text { EIB14/ }\end{array}$ \\
\hline $\mathrm{H}$ & $\begin{array}{l}\text { Dot density grain } \\
\text { and specialty } \\
\text { crops (2007) }\end{array}$ & Map report & & National & 6 & $\begin{array}{l}\text { Appendix 2, } \\
\text { table 2-5 }\end{array}$ & $\begin{array}{l}\text { U.S. Department } \\
\text { of Agriculture, } \\
\text { 2009a }\end{array}$ & $\begin{array}{l}\text { http://www.agcensus.usda.gov/ } \\
\text { Publications/2007/Online_Highlights/ } \\
\text { Ag_Atlas_Maps/Crops_and_Plants/ } \\
\text { index.asp }\end{array}$ \\
\hline I & $\begin{array}{l}\text { National Elevation } \\
\text { Data resampled to }\end{array}$ & $\begin{array}{l}\text { Geospatial raster } \\
\text { dataset }\end{array}$ & $\begin{array}{l}100 \mathrm{~m} \text {, resampled } \\
\text { from 30-m dataset }\end{array}$ & Local & 7 & & Falcone, 2003 & $\begin{array}{l}\text { ftp://ftpext.usgs.gov/pub/er/va/reston/ } \\
\text { NAWQA_ENS/GIS_DATA/elevation/ }\end{array}$ \\
\hline
\end{tabular}


Table 8-1. Summary of data sources and online links to datasets. - Continued

$[\mathrm{m}$, meters $]$

\begin{tabular}{|c|c|c|c|c|c|c|c|c|}
\hline $\begin{array}{l}\text { Index } \\
\text { letter }\end{array}$ & Dataset name & Type of data & $\begin{array}{l}\text { Resolution (cell size) } \\
\text { in square meters }\end{array}$ & Scale & Figures & Tables & Reference & Link \\
\hline $\mathrm{J}$ & $\begin{array}{l}\text { Combined slope } \\
\text { and cropland bar } \\
\text { graph (fig. 7) and } \\
\text { map (fig. 8) }\end{array}$ & $\begin{array}{l}\text { Geospatial raster data } \\
\text { generated from } \mathrm{F} \\
\text { and I }\end{array}$ & $\begin{array}{l}100 \mathrm{~m} \text { resampled to } \\
56 \mathrm{~m}\end{array}$ & Local & 7,8 & $\begin{array}{l}\text { Appendix } 3 \text {, } \\
\text { tables } 3-1 \text { and } \\
3-2\end{array}$ & $\begin{array}{l}\text { Generated for this } \\
\text { report }\end{array}$ & \\
\hline $\mathrm{K}$ & $\begin{array}{l}\text { Average growing } \\
\text { degree-day }\end{array}$ & $\begin{array}{l}\text { Map, (geospatial raster } \\
\text { dataset from Leon- } \\
\text { ard Coop, Oregon } \\
\text { State University, } \\
\text { written commun., } \\
\text { 2009) }\end{array}$ & $1,000 \mathrm{~m}$ & Local & 9 & & $\begin{array}{l}\text { Oregon State Uni- } \\
\text { versity, } 2010\end{array}$ & http://uspest.org/wea/indextable.html \\
\hline $\mathrm{L}$ & $\begin{array}{l}\text { Combined growing } \\
\text { degree-day and } \\
\text { cropland }\end{array}$ & $\begin{array}{l}\text { Geospatial raster data } \\
\text { generated from } \mathrm{F} \\
\text { and } \mathrm{K}\end{array}$ & $\begin{array}{l}1,000 \mathrm{~m} \text { resampled } \\
\text { to } 56 \mathrm{~m}\end{array}$ & Local & 9 & $\begin{array}{l}\text { Appendix 4, } \\
\text { table 4-1 }\end{array}$ & $\begin{array}{l}\text { Oregon State Uni- } \\
\text { versity, } 2008\end{array}$ & \\
\hline M & $\begin{array}{l}\text { Average precipita- } \\
\quad \text { tion }\end{array}$ & $\begin{array}{l}\text { Geospatial raster } \\
\text { dataset }\end{array}$ & $1,000 \mathrm{~m}$ & Local & 10 & & $\begin{array}{l}\text { Generated for this } \\
\text { report }\end{array}$ & http://www.prism.oregonstate.edu/ \\
\hline $\mathrm{N}$ & $\begin{array}{l}\text { Combined precipita- } \\
\text { tion and cropland }\end{array}$ & $\begin{array}{l}\text { Geospatial raster data } \\
\text { generated from } \mathrm{F} \\
\text { and } \mathrm{M}\end{array}$ & $\begin{array}{l}1,000 \mathrm{~m} \text { resampled } \\
\text { to } 56 \mathrm{~m}\end{array}$ & Local & 10 & $\begin{array}{l}\text { Appendix 4, } \\
\text { table 4-2 }\end{array}$ & $\begin{array}{l}\text { Generated for this } \\
\text { report }\end{array}$ & \\
\hline $\mathrm{O}$ & $\begin{array}{l}\text { Threshold for grow- } \\
\text { ing degree days } \\
\text { for selected crops }\end{array}$ & Report & & Global & 11 & $\begin{array}{l}\text { Appendix } 4, \\
\text { table } 4-3\end{array}$ & $\begin{array}{l}\text { Fischer and others, } \\
2002\end{array}$ & $\begin{array}{l}\text { http://www.iiasa.ac.at/Research/LUC/ } \\
\quad \text { GAEZ/index.htm }\end{array}$ \\
\hline $\mathrm{P}$ & $\begin{array}{l}\text { Threshold for water } \\
\text { requirements for } \\
\text { selected crops }\end{array}$ & Report & & Global & 11 & $\begin{array}{l}\text { Appendix } 4, \\
\text { table } 4-3\end{array}$ & $\begin{array}{l}\text { Brouwer and } \\
\text { Heibloem, 1986; }\end{array}$ & $\begin{array}{l}\text { http://www.fao.org/docrep/s2022e/ } \\
\quad \text { s2022e07.htm }\end{array}$ \\
\hline Q & $\begin{array}{l}\text { Dot density maps } \\
\text { of selected crops, } \\
2007\end{array}$ & Map report & & National & 11 & $\begin{array}{c}\text { Appendix } 4, \\
\text { table } 4-4\end{array}$ & $\begin{array}{l}\text { U.S. Department } \\
\text { of Agriculture, } \\
\text { 2009a }\end{array}$ & $\begin{array}{l}\text { http://www.agcensus.usda.gov/ } \\
\text { Publications/2007/Online_Highlights/ } \\
\text { Ag_Atlas_Maps/Crops_and_Plants/ } \\
\text { index.asp }\end{array}$ \\
\hline $\mathrm{R}$ & $\begin{array}{l}\text { Favorable climate } \\
\text { for selected crops }\end{array}$ & $\begin{array}{l}\text { Generated from } \mathrm{L} \text { and } \\
\mathrm{N} \text { based on thresh- } \\
\text { olds } \mathrm{O} \text { and } \mathrm{P} \text {, and } \\
\text { dot density maps of } \\
\text { crops Q }\end{array}$ & & National & 11 & & $\begin{array}{l}\text { Generated for this } \\
\text { report }\end{array}$ & \\
\hline S & $\begin{array}{l}\text { Water withdrawals } \\
\text { for irrigation }\end{array}$ & Tabular dataset & & County & 12 & & $\begin{array}{l}\text { Kenney and others, } \\
2009\end{array}$ & http://water.usgs.gov/watuse/data/2005/ \\
\hline
\end{tabular}


$[\mathrm{m}$, meters $]$

\begin{tabular}{|c|c|c|c|c|c|c|c|c|}
\hline $\begin{array}{l}\text { Index } \\
\text { letter }\end{array}$ & Dataset name & Type of data & $\begin{array}{l}\text { Resolution (cell size) } \\
\text { in square meters }\end{array}$ & Scale & Figures & Tables & Reference & Link \\
\hline $\mathrm{T}$ & $\begin{array}{l}\text { Extent of irrigated } \\
\text { cropland }\end{array}$ & $\begin{array}{l}\text { Geospatial raster data } \\
\text { generated from } \mathrm{F} \\
\text { and } \mathrm{S}\end{array}$ & $\begin{array}{l}56 \text { m resampled } \\
\text { from } 1,000-\mathrm{m} \\
\text { county boundar- } \\
\text { ies }\end{array}$ & County & 12 & & $\begin{array}{l}\text { Generated for this } \\
\text { report }\end{array}$ & \\
\hline $\mathrm{U}$ & $\begin{array}{l}\text { Dot density maps } \\
\text { of irrigated crop- } \\
\text { land, } 2007\end{array}$ & Map report & & National & 13 & & $\begin{array}{l}\text { U.S. Department } \\
\text { of Agriculture, } \\
\text { 2009a }\end{array}$ & $\begin{array}{l}\text { http://www.agcensus.usda.gov/ } \\
\text { Publications/2007/Online_Highlights/ } \\
\text { Ag_Atlas_Maps/Crops_and_Plants/ } \\
\text { index.asp }\end{array}$ \\
\hline V & $\begin{array}{l}\text { Areas of groundwa- } \\
\text { ter-level decline }\end{array}$ & $\begin{array}{l}\text { Geospatial polygon } \\
\text { dataset }\end{array}$ & $\begin{array}{l}\text { Generalized poly- } \\
\text { gons (resolution } \\
\text { unknown) }\end{array}$ & National & 14 & & $\begin{array}{l}\text { Report: Reilly and } \\
\text { others, 2008; } \\
\text { Geospatial data- } \\
\text { set from William } \\
\text { Cunningham, } \\
\text { U.S. Geological } \\
\text { Survey, written } \\
\text { commun., } 2011\end{array}$ & http://pubs.usgs.gov/circ/1323/ \\
\hline W & $\begin{array}{l}\text { Wells with measured } \\
\text { groundwater-level } \\
\text { decline }\end{array}$ & $\begin{array}{l}\text { Geospatial point } \\
\text { dataset }\end{array}$ & $\begin{array}{l}\text { Variable accuracy- } \\
\text { documented in } \\
\text { the U.S. Geo- } \\
\text { logical Survey, } \\
\text { National Water } \\
\text { Information Sys- } \\
\text { tem database }\end{array}$ & Local & 14 & & $\begin{array}{l}\text { Report: Reilly and } \\
\text { others, 2008; List } \\
\text { of wells used in } \\
\text { the report were } \\
\text { provided by } \\
\text { William Cunning- } \\
\text { ham, U.S. Geo- } \\
\text { logical Survey, } \\
\text { written commun., } \\
2011\end{array}$ & $\begin{array}{c}\text { http://pubs.usgs.gov/circ/1323/ and } \\
\text { http://waterdata.usgs.gov/nwis }\end{array}$ \\
\hline $\mathrm{X}$ & $\begin{array}{l}\text { Areas with } 1 \text { or } \\
\text { more wells that } \\
\text { have measured } \\
\text { groundwater-level } \\
\text { decline }\end{array}$ & $\begin{array}{l}\text { Geospatial raster data } \\
\text { generated from } W\end{array}$ & $10,000 \mathrm{~m}$ & Regional & 14 & & $\begin{array}{l}\text { Generated for this } \\
\text { report }\end{array}$ & \\
\hline $\mathrm{Y}$ & $\begin{array}{l}\text { Cropland in } \\
\text { areas that have } \\
\text { groundwater-level } \\
\text { decline }\end{array}$ & $\begin{array}{l}\text { Geospatial raster data } \\
\text { generated from } \mathrm{F}, \mathrm{V}, \\
\text { and } \mathrm{X}\end{array}$ & $\begin{array}{l}56 \mathrm{~m} \text { resampled } \\
\text { from } 10,000 \mathrm{~m}\end{array}$ & Regional & 14 & & $\begin{array}{l}\text { Generated for this } \\
\text { report }\end{array}$ & \\
\hline
\end{tabular}


Table 8-1. Summary of data sources and online links to datasets.-Continued

[m, meters]

\begin{tabular}{|c|c|c|c|c|c|c|c|c|}
\hline $\begin{array}{l}\text { Index } \\
\text { letter }\end{array}$ & Dataset name & Type of data & $\begin{array}{l}\text { Resolution (cell size) } \\
\text { in square meters }\end{array}$ & Scale & Figures & Tables & Reference & Link \\
\hline Z & $\begin{array}{l}\text { Dot density maps } \\
\text { for fertilzer and } \\
\text { manure }\end{array}$ & Map report & & National & 15 & & $\begin{array}{l}\text { U.S. Department } \\
\text { of Agriculture, } \\
2009 \mathrm{a}\end{array}$ & $\begin{array}{l}\text { http://www.agcensus.usda.gov/ } \\
\text { Publications/2007/Online_Highlights/ } \\
\text { Ag_Atlas_Maps/Farms/index.asp). }\end{array}$ \\
\hline AA & $\begin{array}{l}\text { Percentage of crop- } \\
\text { land treated with } \\
\text { fertilizer }\end{array}$ & Tabular data & & National & 15 & & $\begin{array}{l}\text { U.S. Department } \\
\text { of Agriculture, } \\
2010 \mathrm{a}\end{array}$ & $\begin{array}{l}\text { http://www.ers.usda.gov/Data/ } \\
\text { FertilizerUsel }\end{array}$ \\
\hline $\mathrm{AB}$ & $\begin{array}{l}\text { Land capability } \\
\text { class (from U.S. } \\
\text { General Soils } \\
\text { Map) }\end{array}$ & $\begin{array}{l}\text { Geospatial vector and } \\
\text { tabular dataset }\end{array}$ & $\begin{array}{l}\text { Approximately } \\
6,000 \mathrm{~m}\end{array}$ & Regional & 16 & & $\begin{array}{l}\text { U.S. Department of } \\
\text { Agriculture, } 2006\end{array}$ & $\begin{array}{l}\text { http://soildatamart.nrcs.usda.gov/ } \\
\text { USDGSM.aspx }\end{array}$ \\
\hline $\mathrm{AC}$ & $\begin{array}{l}\text { Cropland on each } \\
\text { land capability } \\
\text { class }\end{array}$ & $\begin{array}{l}\text { Geospatial raster data } \\
\text { generated from } \mathrm{F} \\
\text { and } \mathrm{AB}\end{array}$ & $\begin{array}{r}56 \mathrm{~m} \text { resampled } \\
\text { from } 6,000 \mathrm{~m}\end{array}$ & Regional & 16 & $\begin{array}{l}\text { Appendix } 5 \text {, } \\
\text { table } 5-1\end{array}$ & $\begin{array}{l}\text { Generated for this } \\
\text { report }\end{array}$ & \\
\hline $\mathrm{AD}$ & $\begin{array}{l}\text { Cropland on soils } \\
\text { that have limita- } \\
\text { tions }\end{array}$ & $\begin{array}{l}\text { Geospatial raster data } \\
\text { generated from } \mathrm{F} \\
\text { and } \mathrm{AB}\end{array}$ & $\begin{array}{r}56 \mathrm{~m} \text { resampled } \\
\text { from } 6,000 \mathrm{~m}\end{array}$ & Regional & 17 & & $\begin{array}{l}\text { Generated for this } \\
\text { report }\end{array}$ & \\
\hline $\mathrm{AE}$ & $\begin{array}{l}\text { Soil hazard class } \\
\text { (from U.S. Gen- } \\
\text { eral Soils Map) }\end{array}$ & $\begin{array}{l}\text { Geospatial vector and } \\
\text { tabular dataset }\end{array}$ & $\begin{array}{l}\text { Approximately } \\
6,000 \mathrm{~m}\end{array}$ & Regional & 18 & & $\begin{array}{l}\text { U.S. Department of } \\
\text { Agriculture, } 2006\end{array}$ & $\begin{array}{l}\text { http://soildatamart.nrcs.usda.gov/ } \\
\text { USDGSM.aspx }\end{array}$ \\
\hline $\mathrm{AF}$ & $\begin{array}{r}\text { Cropland on soils in } \\
\text { each hazard class }\end{array}$ & $\begin{array}{l}\text { Geospatial raster data } \\
\text { generated from } \mathrm{F} \\
\text { and } \mathrm{AE}\end{array}$ & $\begin{array}{r}56 \mathrm{~m} \text { resampled } \\
\text { from } 6,000 \mathrm{~m}\end{array}$ & Regional & 18 & $\begin{array}{l}\text { Appendix } 6 \\
\text { table } 6-1\end{array}$ & $\begin{array}{l}\text { Generated for this } \\
\text { report }\end{array}$ & \\
\hline AG & $\begin{array}{l}\text { Cropland on soils in } \\
\text { each hazard class } \\
\text { (separated by } \\
\text { hazard) }\end{array}$ & $\begin{array}{l}\text { Geospatial raster data } \\
\text { generated from } \mathrm{F} \\
\text { and } \mathrm{AE}\end{array}$ & $\begin{array}{r}56 \mathrm{~m} \text { resampled } \\
\text { from } 6,000 \mathrm{~m}\end{array}$ & Regional & 19 & & $\begin{array}{l}\text { Generated for this } \\
\text { report }\end{array}$ & \\
\hline $\mathrm{AH}$ & $\begin{array}{l}\text { Cropland on soils } \\
\text { where artificial } \\
\text { drainage is likely }\end{array}$ & $\begin{array}{l}\text { Geospatial raster } \\
\text { generated from AE } \\
\text { (Water hazard class) }\end{array}$ & $\begin{array}{l}56 \mathrm{~m} \text { resampled } \\
\text { from } 6,000 \mathrm{~m}\end{array}$ & Regional & 20 & $\begin{array}{l}\text { Appendix } 6, \\
\text { table } 6-2\end{array}$ & $\begin{array}{l}\text { Generated for this } \\
\text { report }\end{array}$ & \\
\hline
\end{tabular}


Table 8-1. Summary of data sources and online links to datasets.-Continued

$[\mathrm{m}$, meters]

\begin{tabular}{|c|c|c|c|c|c|c|c|c|}
\hline $\begin{array}{l}\text { Index } \\
\text { letter }\end{array}$ & Dataset name & Type of data & $\begin{array}{l}\text { Resolution (cell size) } \\
\text { in square meters }\end{array}$ & Scale & Figures & Tables & Reference & Link \\
\hline AI & $\begin{array}{l}\text { Areas where surface } \\
\text { or subsurface } \\
\text { drainage is likely }\end{array}$ & $\begin{array}{l}\text { Geospatial raster da- } \\
\text { taset based on } 1992 \\
\text { Natural Resources } \\
\text { Inventory county- } \\
\text { level agricultural } \\
\text { practices (c606- } \\
\text { subsurface drain- } \\
\text { age and C607) and } \\
\text { 1992 National Land } \\
\text { Cover }\end{array}$ & $1,000 \mathrm{~m}$ & County & 20 & & $\begin{array}{l}\text { Michael Wieczorek, } \\
\text { U.S. Geological } \\
\text { Survey, digital } \\
\text { dataset, } 2002\end{array}$ & $\begin{array}{l}\text { http://water.usgs.gov/GIS/metadata/ } \\
\text { usgswrd/XML/ofr041189606.xml }\end{array}$ \\
\hline AJ & $\begin{array}{l}\text { Average annual run- } \\
\text { off (1971-2000) }\end{array}$ & $\begin{array}{l}\text { Geospatial raster } \\
\text { dataset }\end{array}$ & $1,000 \mathrm{~m}$ & $\begin{array}{l}\text { Regional } \\
\quad \text { (source data } \\
1: 2,000,000)\end{array}$ & 21 & & $\begin{array}{l}\text { David M. Wolock, } \\
\text { U.S. Geological } \\
\text { Survey, written } \\
\text { commun., } 2009\end{array}$ & $\begin{array}{l}\text { Older dataset available from : http:// } \\
\text { water.usgs.gov/GIS/metadata/usgswrd/ } \\
\text { XML/runoff.xml }\end{array}$ \\
\hline $\mathrm{AK}$ & $\begin{array}{l}\text { Cropland on annual } \\
\text { runoff }\end{array}$ & $\begin{array}{l}\text { Geospatial raster data } \\
\text { generated from } \mathrm{F} \\
\text { and AJ }\end{array}$ & $\begin{array}{l}56 \mathrm{~m} \text { resampled } \\
\text { from } 1,000 \mathrm{~m}\end{array}$ & Regional & 21 & $\begin{array}{l}\text { Appendix } 6 \\
\text { table } 6-3\end{array}$ & $\begin{array}{l}\text { Generated for this } \\
\text { report }\end{array}$ & \\
\hline $\mathrm{AL}$ & $\begin{array}{l}\text { Average annual re- } \\
\text { charge (1971- } \\
\text { 2000) }\end{array}$ & $\begin{array}{l}\text { Geospatial raster } \\
\text { dataset }\end{array}$ & $1,000 \mathrm{~m}$ & $\begin{array}{l}\text { Regional } \\
\quad \text { (source data } \\
1: 2,000,000)\end{array}$ & 22 & & $\begin{array}{l}\text { David M. Wolock, } \\
\text { U.S. Geological } \\
\text { Survey, written } \\
\text { commun., } 2009\end{array}$ & $\begin{array}{l}\text { Older dataset available from : http:// } \\
\text { water.usgs.gov/GIS/metadata/usgswrd/ } \\
\text { XML/rech48grd.xml }\end{array}$ \\
\hline $\mathrm{AM}$ & $\begin{array}{l}\text { Cropland on annual } \\
\text { recharge }\end{array}$ & $\begin{array}{l}\text { Geospatial raster data } \\
\text { generated from } \mathrm{F} \\
\text { and } \mathrm{AL}\end{array}$ & $\begin{array}{l}56 \mathrm{~m} \text { resampled } \\
\text { from } 1,000 \mathrm{~m}\end{array}$ & Regional & 22 & $\begin{array}{c}\text { Appendix } 6 \\
\text { table } 6-4\end{array}$ & $\begin{array}{l}\text { Generated for this } \\
\text { report }\end{array}$ & \\
\hline AN & $\begin{array}{l}\text { Potential Natural } \\
\text { Vegetation with } \\
\text { wetlands }\end{array}$ & $\begin{array}{l}\text { Geospatial raster data } \\
\text { generated from } \\
\text { A and AE (Water } \\
\text { hazard class) }\end{array}$ & $\begin{array}{l}56 \mathrm{~m} \text { resampled } \\
\text { from } 6,000 \mathrm{~m}\end{array}$ & Regional & 23 & & $\begin{array}{l}\text { Generated for this } \\
\text { report }\end{array}$ & \\
\hline $\mathrm{AO}$ & $\begin{array}{l}\text { Cropland on } \\
\text { potential natural } \\
\text { vegetation and } \\
\text { wetlands }\end{array}$ & $\begin{array}{l}\text { Geospatial raster data } \\
\text { generated from } \mathrm{F} \\
\text { and AN }\end{array}$ & $\begin{array}{l}56 \mathrm{~m} \text { resampled } \\
\text { from } 6,000 \mathrm{~m}\end{array}$ & Regional & 23 & $\begin{array}{l}\text { Appendix } 7 \text {, } \\
\text { tables } 7-1,7-2, \\
\text { and } 7-3\end{array}$ & $\begin{array}{l}\text { Generated for this } \\
\text { report }\end{array}$ & \\
\hline
\end{tabular}




\section{References Cited in the Appendixes}

Brouwer, C., and Heibloem M., 1986, Irrigation water management-Training manual no. 3, Irrigation water needs: International Institute for Land Reclamation and Improvement and FAO Land and Water Development Division, accessed February 2011 at $h t t p: / / w w w$.fao.org/docrep/ s2022e/s2022e00.htm\#Contents.

Falcone, James, 2003, National elevation data, resampled to 100 m: Reston, Va., U.S. Geological Survey geospatial data, accessed October 2009 at ftp://ftpext.usgs.gov/pub/er/va/ reston/NAWQA_ENS/GIS_DATA/elevation/.

Fischer, Günther; van Velthuizen, Harrij; Sha, Mahendra; and Nachtergaele, Freddy, 2002, Global agro-ecological assessment for agriculture in the 21st century-Methodology and results: Laxenburg, Austria, International Institute for Applied Systems Analysis, 119 p., accessed September 2010 at http://www.iiasa.ac.at/Admin/PUB/Documents/ RR-02-002.pdf.

Gebert, W.A., Graczyk, D.J., and Krug, W.R., 1987, Average annual runoff in the United States, 1951-80: Madison, Wis., U.S. Geological Survey geospatial dataset, accessed March 2009 at http://water.usgs.gov/GIS/metadata/usgswrd/XML/ runoff.xml.

Gesch, D.B., 2007, The National Elevation Dataset, in Maune, D.F., ed., Digital elevation model technologies and applications - The DEM users manual (2d ed.): Bethesda, Md., American Society for Photogrammetry and Remote Sensing, p. 99-118.

Gesch, D., Oimoen, M., Greenlee, S., Nelson, C., Steuck, M., and Tyler, D., 2002, The National Elevation Dataset: Photogrammetric Engineering and Remote Sensing, v. 68, no. 1, p. $5-11$.

Helms, Douglas, 1992, The development of the land capability classification, in Helms, Douglas, Readings in the history of the Soil Conservation Service: Washington, D.C., U.S. Department of Agriculture, Natural Resources Conservation Service, p. 60-73, accessed January 2010 at http://www.nrcs.usda.gov/about/history/articles/ landclassification.html.

Jaynes, D.B., and James, D., 2007, The extent of farm drainage in the United States: Paper presented at the annual meeting of the Soil And Water Conservation Society, Saddlebrook Resort, Tampa, Fla., July 21, 2007; abstract accessed December 2010 at http://www.allacademic.com/ meta/p173977_index.html.

Kenny, J.F., Barber, N.L., Hutson, S.S., Linsey, K.S., Lovelace, J.K., and Maupin, M.A., 2009, Estimated use of water in the United States in 2005: U.S. Geological Survey Circular 1344, 52 p.
Küchler, A.W., 1964, The potential natural vegetation of the conterminous United States: New York, American Geographical Society Special Publication 36, 1 sheet.

Lubowski, R.N.; Vesterby, Marlow; Bucholtz, Shawn; Baez, Alba; and Roberts, M.J., 2006, Major uses of land in the United States, 2002: U.S. Department of Agriculture, Economic Research Service, Economic Information Bulletin 14, 47 p. (Also available at $h t t p: / / w w w . e r s . u s d a . g o v /$ Publications/EIB14/.)

Missoula Fire Sciences Laboratory, 2001, Potential natural vegetation groups, version 2000: Missoula, Mont., U.S. Department of Agriculture, Forest Service, Rocky Mountain Research Station, Missoula Fire Sciences Laboratory, geospatial data, accessed November 2009 at http://www.fS.fed.us/fire/fuelman/pnv.htm.

Oregon State University, 2008, U.S. precipitation 30-arcsec (800-m) normals (1971-2000): Corvallis, Oreg., The PRISM Climate Group, geospatial data, accessed November 2009 at $h t t p: / / w w w . p r i s m . o r e g o n s t a t e . e d u /$.

Oregon State University [2010], Degree-day maps created daily using $50^{\circ} \mathrm{F}$ lower threshold-Normals: Corvallis, Oreg., Integrated Plant Protection Center (http://uspest.org/ wea), accessed March 2010 at http://ippc2.orst.edu/US/ ddmaps.html.

Ramankutty, Navin; Heller, Elizabeth; and Rhemtulla, Jeanine, 2010, Prevailing myths about agricultural abandonment and forest regrowth in the United States: Annals of the Association of American Geographers, v. 100, no. 3, p. 502-512, supplemental material, accessed February 2011 at http://www.informaworld.com/smpp/ftinterface $\sim d b=$ all $\sim$ con tent $=a 922418004$ ? ta $b=$ multimedia .

Reilly, T.E., Dennehy, K.F., Alley, W.M., and Cunningham, W.L., 2008, Ground-water availability in the United States: U.S. Geological Survey Circular 1323, 70 p. (Also available online at http://pubs.usgs.gov/circ/1323/.)

U.S. Department of Agriculture, 2005, 2002 Census of Agriculture, Geographic Area Series Publications, Volume 1, Chapter 2-County level data: Washington D.C., National Agricultural Statistical Service, CD-ROM. (Also available at $h t t p: / / w w w . a g c e n s u s . u s d a . g o v / P u b l i c a t i o n s / 2002 / i n d e x$. asp.)

U.S. Department of Agriculture, 2006, U.S. general soil map (STATSGO) data: Natural Resources Conservation Service geospatial data, accessed February 2010 at http://soildatamart.nrcs.usda.gov/USDGSM.aspx. 


\section{Environmental Factors That Influence the Location of Crop Agriculture in the Conterminous United States}

U.S. Department of Agriculture, 2009a, 2007 Census of Agriculture, Online Highlights, Ag Atlas Maps, Crops and Plants: Washington D.C., National Agricultural Statistical Service online data, accessed January 2011 at $h t t p: / / w w w$. agcensus.usda.gov/Publications/2007/Online_Highlights/ Ag_Atlas_Maps/Crops_and_Plants/index.asp.

U.S. Department of Agriculture, 2010a, Fertilizer use and price: Economic Research Service online data, accessed January 2011 at $h t t p: / / w w w . e r s . u s d a . g o v / D a t a /$ FertilizerUse/.

U.S. Department of Agriculture, 2010b, 2009 [state] Cropland Data Layer: National Agricultural Statistics Service, geospatial data, accessed February 2010 at http://www.nass. usda.gov/research/Cropland/SARSla.htm.
Waisanen, P.J., and Bliss, N.B., 2002, Changes in population and agricultural land in conterminous United States counties, 1790 to 1997: Global Biogeochemical Cycles, v. 16, no. 4, 1137, doi:10.1029/2001GB001843, 2002. (Also available at http://edcintl.cr.usgs.gov/ip/carbon_cycle/ pdfs/2001GB001843.pdf.)

Wolock, D.M., 2003, Estimated mean annual natural ground-water recharge in the conterminous United States: U.S. Geological Survey Open-File Report 03-311, geospatial data available at http://water.usgs.gov/GIS/metadata/ usgswrd/XML/rech48grd.xml. 

